DOH $320-034$

PNNL 14878

WDOE 04-05-016

ODOE NUC-007

\title{
Survey of Potential Hanford Site Contaminants in the Upper Sediment for the Reservoirs at McNary, John Day, The Dalles, and Bonneville Dams, 2003
}

February 2005

A Cooperative Environmental Monitoring Project of:

G. Patton

Hanford Site Surface Environmental

Surveillance Project

Pacific Northwest

National Laboratory

Operated by Battelle for the

U.S. Department of Energy

J. Yokel

D. Delistraty

Washington State Department of Ecology

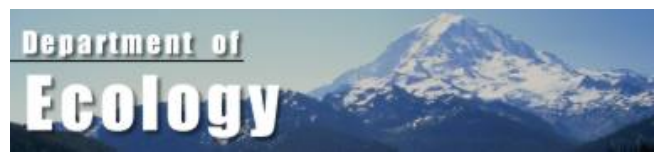

M. Priddy

Washington State Department of Health

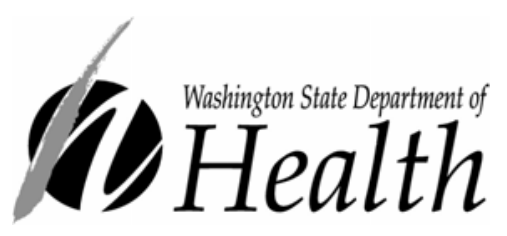

T. Stoops

Oregon Department of Energy

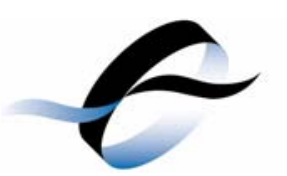

OREGON DEPARTMENT OF E N E R G Y 

DOH 320-034

PNNL 14878

WDOE 04-05-016

ODOE NUC-007

\section{Survey of Potential Hanford Site Contaminants in the Upper Sediment for the Reservoirs at McNary, John Day, The Dalles, and Bonneville Dams, 2003}

February 2005

A Cooperative Environmental Monitoring Project

M. Priddy, Washington State Department of Health

G. Patton, Hanford Site Surface Environmental Surveillance Project

J. Yokel, Washington State Department of Ecology

D. Delistraty, Washington State Department of Ecology

T. Stoops, Oregon Department of Energy

\section{Washington State Department of Health}

For more information or additional

copies of this report, contact:

Environmental Radiation Section

Office of Radiation Protection

Department of Health

7171 Cleanwater Lane, Bldg. 5

P.O. Box 47827

Olympia WA 98504

Phone: 360-236-3251

Email: ENVRAD@doh.wa.gov

Fax: 360-236-2255 



\title{
DISCLAIMER
}

This report was prepared as an account of work sponsored by an agency of the United States Government. Neither the United States Government nor any agency thereof, nor Battelle Memorial Institute, nor any of their employees, makes any warranty, express or implied, or assumes any legal liability or responsibility for the accuracy, completeness, or usefulness of any information, apparatus, product, or process disclosed, or represents that its use would not infringe privately owned rights. Reference herein to any specific commercial product, process, or service by trade name, trademark, manufacturer, or otherwise does not necessarily constitute or imply its endorsement, recommendation, or favoring by the United States Government or any agency thereof, or Battelle Memorial Institute. The views and opinions of authors expressed herein do not necessarily state or reflect those of the United States Government or any agency thereof.

\author{
PACIFIC NORTHWEST NATIONAL LABORATORY \\ operated by \\ BATTELLE \\ for the \\ UNITED STATES DEPARTMENT OF ENERGY \\ under Contract DE-AC06-76RL01830
}

Printed in the United States of America

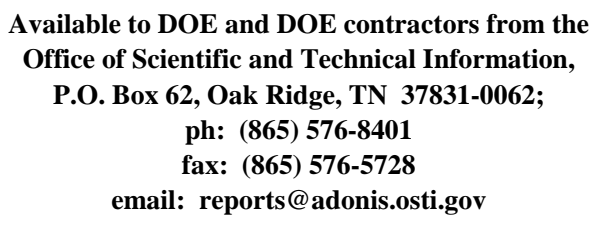

Available to the public from the National Technical Information Service, U.S. Department of Commerce, 5285 Port Royal Rd., Springfield, VA 22161

ph: (800) 553-6847

fax: (703) 605-6900

email: orders@ntis.fedworld.gov

online ordering: http://www.ntis.gov/ordering.htm 



\section{Summary}

Staff from the Oregon Department of Energy (ODOE) (representing the Oregon Hanford Waste Board) met with representatives of the Washington Department of Health (DOH) in the spring of 2003 and requested that an environmental survey of the upstream pools of the four lower Columbia River dams, (McNary Dam, John Day Dam, The Dalles Lock and Dam, and Bonneville Dam) be conducted.

In July of 2003, Washington Departments of Health and Ecology met with the U.S. Department of Energy (U.S. DOE) and U.S. DOE's contractor Pacific Northwest National Laboratory (PNNL) to discuss this effort. It was agreed to collect sediment samples and adjacent beach sediment (where available) from each pool. In addition, river water samples would be collected at McNary Dam. The results from this study were compared to background values from sediment and water samples collected from the pool upstream of Priest Rapids Dam (upstream of the Hanford Site) by the Hanford Site Surface Environmental Surveillance Project (Poston et al. 2003). Samples were analyzed for radionuclides, chemicals, and physical parameters. In addition, sediment porewater (i.e. the water associated with the sediments) bioassays were conducted. This report presents the results from this multi-agency study.

\section{Abstract}

In the summer of 2003, staff from the Oregon Department of Energy (ODOE) (representing the Oregon Hanford Waste Board) met with representatives of the Washington Department of Health, Washington Department of Ecology, U.S. DOE, and U.S. DOE's contractor Pacific Northwest National Laboratory. At the request of Oregon, the Washington agencies and U.S. DOE agreed to conduct a multi-agency cooperative environmental surveillance study of the four pools (McNary Dam, John Day Dam, The Dalles Lock and Dam, and Bonneville Dam) that are downriver from Hanford Site operations. Sediment samples and adjacent beach sediment (where available) were collected from each pool. In addition, river water samples were collected at McNary Dam. Results from this study were compared to background values from sediment and water samples collect from the pool upstream of Priest Rapids Dam (upstream of the Hanford Site) by the Hanford Site Surface Environmental Surveillance Project (Poston et al. 2003). Samples were analyzed for radionuclides, chemicals, and physical parameters. In addition, sediment porewater (i.e., the water associated with the sediments) bioassays were conducted. This report presents the results from this multi-agency study.

Sediment was readily available at the McNary, John Day, and The Dalles dams; however, there was only limited sediment available at Bonneville Dam. Beach sediment was limited in the sections of the lower reservoirs adjacent to the sampling locations with sediment only available at McNary Dam and at the mouth of Eagle Creek near Bonneville Dam. In general, the river sediment samples were composed primarily of very fine sand, silt, and clay, whereas the beach sediment was composed primarily of medium and coarse sand. 



\section{Acknowledgments}

The authors would like to acknowledge Ken Niles (Oregon Department of Energy), Lynn Albin (Washington State Department of Health), and Robert Fulton (Pacific Northwest National Laboratory) for their assistance in collecting river sediment and water samples. Larry Gadbois (U.S. Environmental Protection Agency) observed the sediment sampling at the John Day Dam and provided peer review comments for this report. Lynn Albin coordinated analytical support for the samples analyzed by the Washington State Department of Health. Erwin Schutfort of Oregon State University provided analytical support for the samples analyzed by the Oregon Department of Energy. Brenda Lasorsa (Pacific Northwest National Laboratory) coordinated analytical support for the non-radiological samples analyzed by Pacific Northwest National Laboratory. Lynn Bisping (Pacific Northwest National Laboratory) provided support for all sample scheduling, generation of sample custody sheets and labels, and database support. Dana Ward (DOE Richland Operations Office), Debra McBaugh (Washington State Department of Health), and Ted Poston (Pacific Northwest National Laboratory) provided input to the sampling design during the initial coordination meeting. Launa Morasch and Jo Lynn Draper (Pacific Northwest National Laboratory) provided editorial support and Kathy Neiderhiser provided text processing. Kristin Felix (Washington State Department of Health) and Eileen Kramer (Washington State Department of Health) provided editorial support. 




\section{Contents}

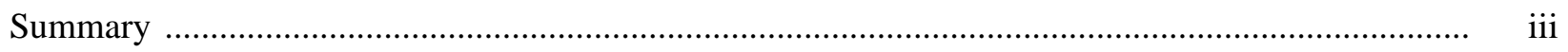

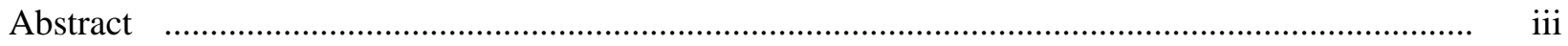

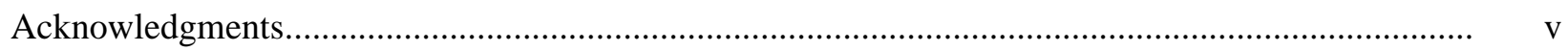

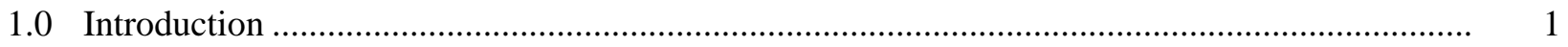

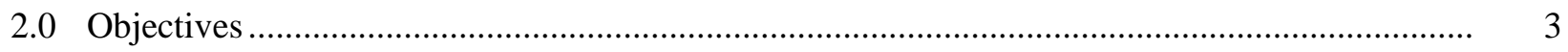

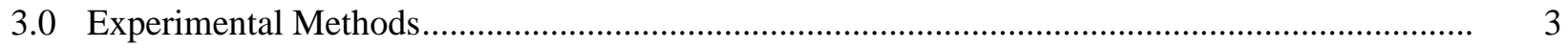

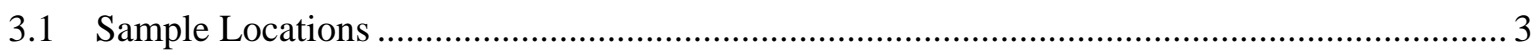

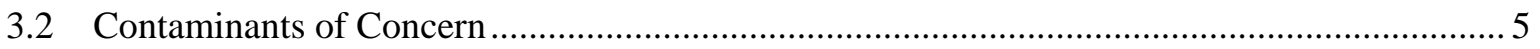

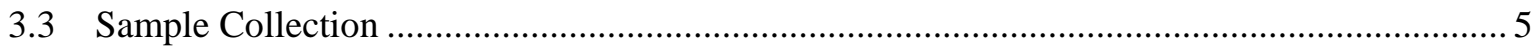

3.4 Radiological and Chemical Analysis......................................................................... 7

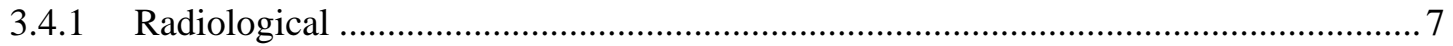

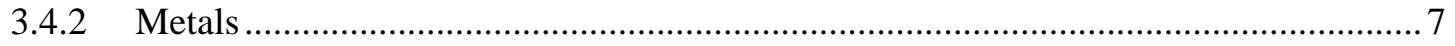

3.4.3 Grain Size and Total Organic Carbon Assays ....................................................... 7

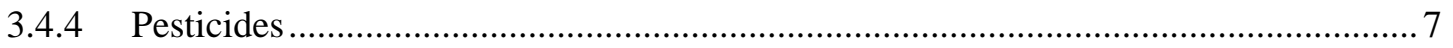

3.4.5 Polychlorinated Biphenyls .............................................................................. 7

3.4.6 Semi-Volatile Organic Compounds ................................................................. 7

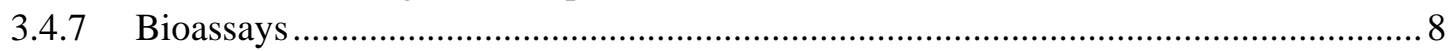

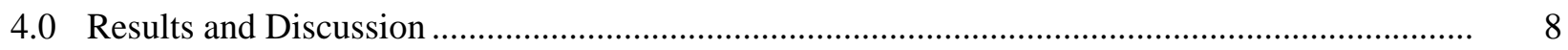

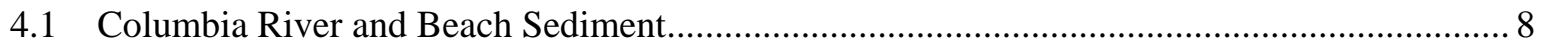

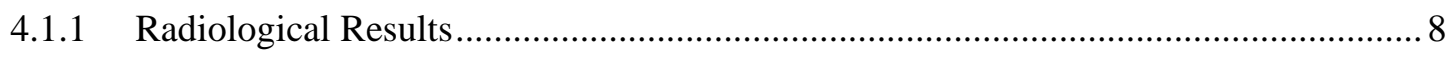

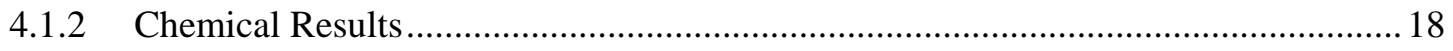

4.1.3 Microtox ${ }^{\circledR}$ and Daphnia IQ Toxicity Test.......................................................... 26

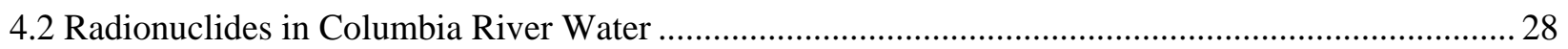

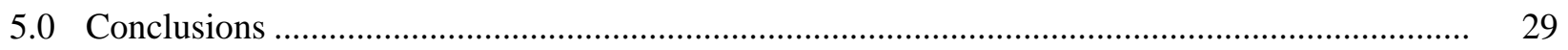

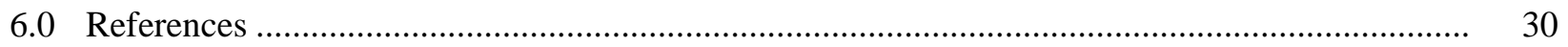




\section{Figures}

Map of Sediment Sampling Locations.

Cesium-137 in Columbia River Sediment.

Total Uranium in Columbia River Sediment................................................................ 17

Plutonium-239/240 in Columbia River Sediment.

Average Simultaneously Extracted Metals/Acid Volatile Sulfide Concentrations in Columbia River Sediment.

Sediment Grain Size Distribution for Columbia River Sediment.

Relationship Between Dapnia IQ Test Results for Sediment Porewater and Average Acid Volatile Sulfide Concentrations in Associated Sediments. 28

\section{Tables}

1 Sediment Sampling Locations, 2003

2 Locations Where Sediment Samples were Successfully Collected .......................................... 9

3 Median Effective Dose for Microtox ${ }^{\circledR}$ and Daphnia IQ Toxicity Tests .................................... 27 



\subsection{Introduction}

As a result of past Hanford Site operations, large quantities of radioactive materials and chemicals were discharged to the Columbia River. Some of these materials deposited on the riverbed as sediment.

Fluctuations in the river stage from dam operations, high river flows during the spring runoff period, and occasional floods have resulted in resuspension, transport, and redeposition of the sediment material. The largest releases of radioactivity and chemicals to the Columbia River occurred from 1956 to 1965 when the single-pass (i.e., Columbia River water was used for direct cooling) nuclear reactors were operating at Hanford (HEDR 1994; DOE 2002). Since the shutdown of the single-pass reactors in the early 1970s, the contaminant burden in the surface sediments has been decreasing as a result of radioactive decay and the subsequent deposition of uncontaminated sediment (Cushing et al. 1981). Radionuclides with long half lives deposited during the operational period of the single pass reactors are still present in the deep sediment of the lower reservoirs and are now covered with layers of more recently deposited sediment. Currently, the upper layer sediments in the Columbia River contain low concentrations of radionuclides and chemicals of Hanford Site origin as well as radionuclides from nuclear weapons testing fallout and chemicals from multiple non-Hanford sources (Beasley et al. 1986; Robertson and Fix 1977; Woodruff et al. 1992; Blanton et al. 1995; DOE 1998; Gibbons 2000). Potential public exposures to radionuclides in surface sediment layers are below the level at which routine surveillance of Columbia River sediments are required (Sula 1980; Wells 1994). However, annual sampling is conducted by the Hanford Site Surface Environmental Surveillance Project and the Washington Department of Heath (DOH) to confirm the low levels and to ensure that no significant changes have occurred for this pathway (Poston et al. 2003; Wells 1994). This annual sampling is conducted at Priest Rapids Dam (upstream from Hanford), at sediment accumulation locations in the Hanford Reach, and at McNary Dam.

The Oregon Health Division conducted environmental sampling at eleven locations from McNary Dam to Astoria on the Columbia River from 1961 to 1993. Sampling included water, river sediment, aquatic vegetation, and fish. Measured levels of radioactive materials were below then-recommended federal and international standards (OHD 1994). Peak concentrations of radioactive materials were detected in the mid-1960s, when Hanford's nine reactors were operating. Radioactivity levels in the Columbia River measured by the Oregon Health Division dropped dramatically following the shutdown the last singlepass reactor. At the time sampling ended, the Oregon Health Division noted "there was no Hanford radioactivity detectable in the Columbia River or the Oregon seacoast” (OHD 1994). In 2003, the Oregon Hanford Waste Board (an advisory board to the Governor and the Legislator of Oregon) issued a report entitled River Without Waste that included recommendations for Columbia River protection (OHWB 2002). One of the recommendations was to resume limited radiological monitoring of the Columbia River, downstream of the Washington border, to ensure that potential contaminants from the Hanford Site do not reach Oregon undetected.

In the summer of 2003, staff from the Oregon Department of Energy (ODOE) (representing the Oregon Hanford Waste Board) approached DOH and expressed an interest in environmental monitoring of surface sediment in the Columbia River, behind the four pools (McNary Dam, John Day Dam, The Dalles Lock and Dam, and Bonneville Dam) that are downriver from Hanford Site operations. Staff from DOH organized a meeting between those two agencies and representatives of the Washington Department of 
Ecology, U.S. DOE, and U.S. DOE's contractor Pacific Northwest National Laboratory. At the request of Oregon, the Washington agencies and U.S. DOE agreed to conduct a multi-agency cooperative environmental surveillance study of surface sediment from the four pools on the lower Columbia River (Figure 1). Sediment samples and adjacent beach sediment (where available) were collected from each pool. In addition, river water samples were collected at McNary Dam. Samples were analyzed for radionuclides, chemicals, and physical parameters. In addition, sediment porewater (i.e., water associated with the sediment) bioassays were conducted. The study was conducted in August 2003 with additional sampling and analysis planned in 2004.

\section{Background on Contaminants of Concern}

Radionuclides typically observed in river sediment have three sources: natural occurring (potassium-40, uranium), atmospheric fallout (cobalt-60, strontium-90, cesium-137, uranium, plutonium), and potential Hanford releases (cobalt-60, strontium-90, cesium-137, europium, uranium, plutonium).

Metals measured in this study have both natural and man-made sources (e.g. upriver mining operations). Many metals are essential nutrients at trace levels and are required for the survival of river flora and fauna. However, elevated levels of metals can cause a wide range of toxic effects. In addition, selected environmental conditions can result in metals combining with other chemicals to form compounds which alter their bioavailability and toxicity (e.g., methylmercury, dimethyarsenic, arsenocholine, arsenosugars). Chemicals containing trace metals were used and discharged in past Hanford Site reactor and chemical processing operations, or have been identified as contaminants of concern as part of site restoration studies because they were suspected of being used and disposed of in the environment. Chromium was used extensively at the Hanford Site. In the 100 Area reactors, sodium dichromate was added to cooling water as a corrosion inhibitor. Residual chromium in soil and groundwater has been found through recent remediation efforts. Chromium was also used for decontamination in the 100, 200, and 300 Areas and for oxidation-state control in the Reduction-Oxidation Plant process. Hexavalent chromium is highly mobile in the groundwater and has been measured in near-shore groundwater wells and Hanford Site riverbank springs (Poston et al. 2003).

The lower Columbia River sediment contains pesticide residues because of their extensive use in Washington and Oregon agriculture. Following World War II, pesticide use on field and tree crops in Washington increased dramatically. In 1992, there were about 35,500 commercial farms in Washington State, with $\sim \$ 178$ million invested in the application of pesticides (Washington Agricultural Statistics Service 1994). Pesticides were routinely detected in groundwater samples in Washington State are Dacthal (DCPA); 1,2-dichloropropane, atrazine, simazine, ethylene dibromide (EDB); 1,2dichloropropane (DCP); and dibromochloropropane (DBCP) (Washington State Department of Ecology 1996). The Hanford Site is not considered to be an important source of pesticides to the Columbia River because pesticide usage was limited compared to the large agricultural usage in the region.

Polychlorinated biphenyls (PCBs) were widely used in electrical equipment such as capacitors and transformers. PCBs are persistent in the environment and tend to bioaccumulate. They can cause damage to the liver and reproductive systems and are suspected of being carcinogenic. PCBs have been shown to be widely distributed in the environment (Erickson 1997). The largest potential Hanford source is from hydraulic fluids from the Hanford Plutonium Finishing Plant; however, the Hanford Site is not considered 
to be a significant source of PCBs in the Columbia River since these compounds have not been routinely detected in Hanford Site groundwater. Historic regional use of PCBs and atmospheric deposition in the Columbia River basin air shed are the most likely source of PCBs in Columbia River sediment (Patton et al. 1994; Patton et al. 1997a; Patton et al. 1997b).

Other organic compounds currently found in Hanford Site groundwater came from waste sites, contaminated soils, and from the large volume of liquid effluents discharged to cribs and trenches during reactor operations. Some organic contaminants continue to migrate into the groundwater and may eventually reach the Columbia River; however, for most compounds, this process has slowed because the major driving force (discharge of liquid effluents to the ground) has ended. Most organic compounds of interest in Hanford Site groundwater are volatile organic compounds (typically organic solvents) which would have little tendency to accumulate in river sediment. A suite of semi-volatile compounds was analyzed for this study because some were detetected in fish tissues in the Columbia River basin (EPA 2002). Semi-volatile compounds detected in fish tissues included guaicols, ethers, phenols, and polycyclic aromatic hydrocarbons (PAHs). The Hanford Site is not considered to be a significant source of semi-volatile organic compounds in the Columbia River since these compounds have not been routinely detected in Hanford Site groundwater (Poston et al. 2003). Regional use of semi-volatile organic compounds and atmospheric deposition in the Columbia River basin air shed are the most likely source of semi-volatile organic compounds for Columbia River sediment (Patton et al. 1994; Patton et al. 1997b).

\subsection{Objectives}

The objectives of this study were to characterize the radiological and chemical conditions existing in the upper-level sediment found in the pools upstream of McNary Dam, John Day Dam, The Dalles Lock and Dam, and Bonneville Dam. Additionally, this study evaluated beach sediment (where available). Water samples were collected at McNary Dam to assist in evaluating potential Hanford contaminants in the lower Columbia River. Water samples were limited to McNary Dam.

\subsection{Experimental Methods}

\subsection{Sample Locations}

Sampling locations are shown in Figure 1 and global positioning system (GPS) coordinates are provided in Table 1. Where available, a beach sediment sample was collected on each shore. For each location, an attempt was made to collect three "deep water sediment” samples from a transect line across the river channel. All sampling locations were identified using a GPS. River sediment samples were compared to upstream control reference data (i.e., sediment not influenced by Hanford operations) from previously collected Pacific Northwest National Laboratory (PNNL) and DOH sediment samples from the impoundments at Priest Rapids Dam (Columbia River) and Ice Harbor Dam (Snake River) (Bisping 2003; Poston et al. 2003). 


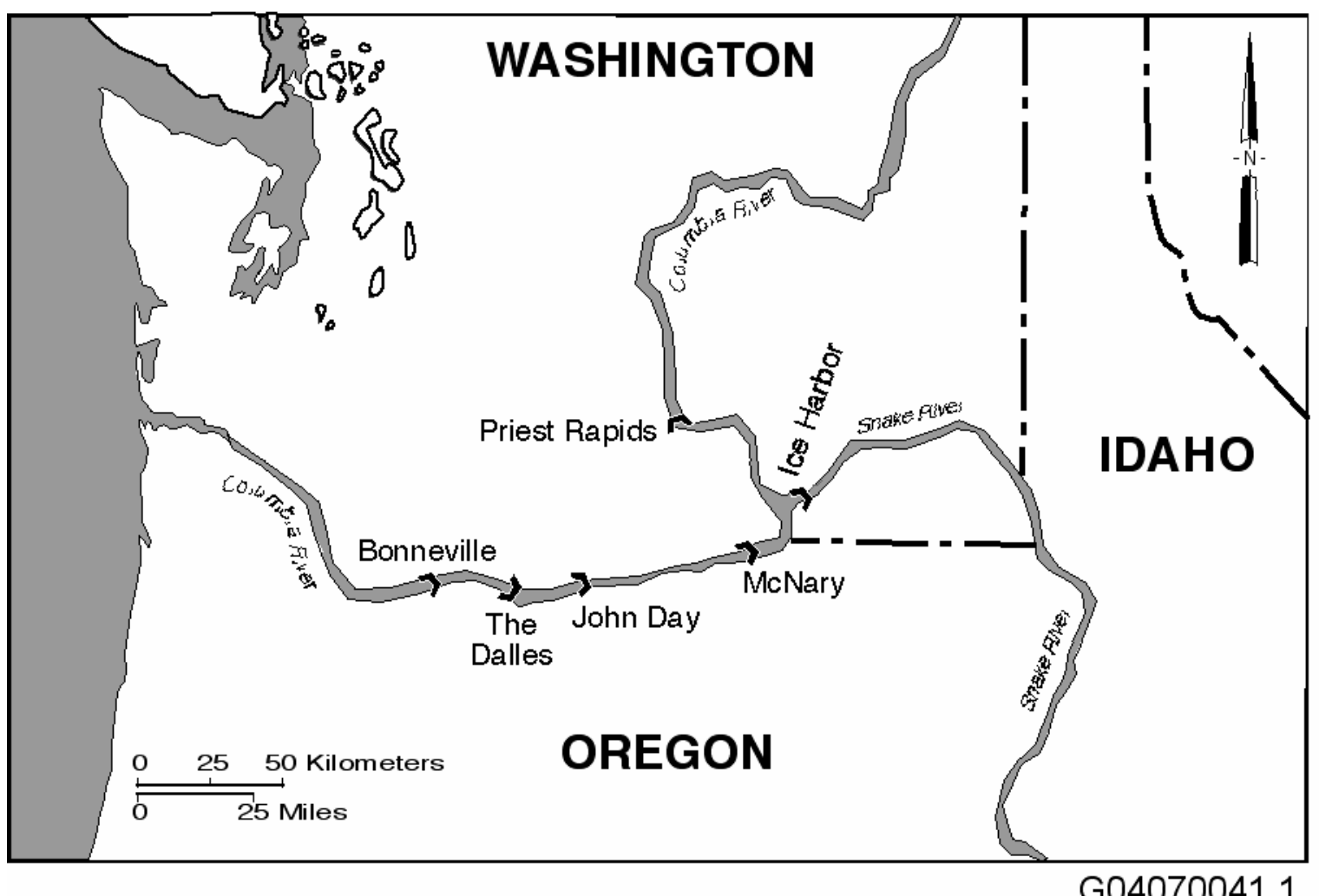

Figure 1. Map of Sediment Sampling Locations.

Table 1. Sediment Sampling Locations, 2003 (degrees_minutes.decimal minutes)

\begin{tabular}{||l|l|c|c||}
\hline \hline Impoundment & \multicolumn{1}{|c|}{ Location } & Latitude & Longitude \\
\hline \hline \multirow{3}{*}{ Bonneville } & OR Shore & $45^{\circ} 38.349^{\prime}$ & $121^{\circ} 56.725^{\prime}$ \\
\cline { 2 - 5 } & OR Beach & $45^{\circ} 34.477^{\prime}$ & $121^{\circ} 55.952^{\prime}$ \\
\hline \multirow{3}{*}{ John Dalles } & OR Shore & $45^{\circ} 37.340^{\prime}$ & $121^{\circ} 06.796^{\prime}$ \\
\cline { 2 - 5 } & WA Shore & $45^{\circ} 37.599^{\prime}$ & $121^{\circ} 07.212^{\prime}$ \\
\hline \multirow{3}{*}{ McNary } & OR Shore & $45^{\circ} 43.075^{\prime}$ & $120^{\circ} 40.763^{\prime}$ \\
\cline { 2 - 5 } & Midway & $45^{\circ} 43.250^{\prime}$ & $120^{\circ} 40.836^{\prime}$ \\
\cline { 2 - 5 } & WA Shore & $45^{\circ} 43.5688^{\prime}$ & $120^{\circ} 41.081^{\prime}$ \\
\cline { 2 - 5 } & OR Beach & $45^{\circ} 55.879^{\prime}$ & $119^{\circ} 15.997^{\prime}$ \\
\cline { 2 - 5 } & OR Shore & $45^{\circ} 55.999^{\prime}$ & $119^{\circ} 15.562^{\prime}$ \\
\cline { 2 - 5 } & 2/3 From OR Shore & $45^{\circ} 56.545^{\prime}$ & $119^{\circ} 15.388^{\prime}$ \\
\cline { 2 - 4 } & WA Shore & $45^{\circ} 56.784^{\prime}$ & $119^{\circ} 15.377^{\prime}$ \\
\cline { 2 - 4 } & WA Beach & $45^{\circ} 56.775^{\prime}$ & $119^{\circ} 14.692^{\prime}$ \\
\hline \hline
\end{tabular}


Bonneville Dam river sediment sampling was only successful on the Oregon side of the river between the ship lock and Bradford Island; attempts to collect sediment at mid-river and on the Washington side of Bradford Island were unsuccessful. Beach sediment was available only on the Oregon shore near the mouth of Eagle Creek. No beach sediment accumulation areas on the Washington shore were observed from the boat launch at Bridge of the Gods to the boat exclusion area at the dam.

The Dalles Lock and Dam river sediment samples were collected $~ 1.6 \mathrm{~km}$ upstream from the dam on the Oregon and Washington side of the river; no mid-river sediment was recovered despite multiple attempts with the sediment dredge. No beach sediment accumulation areas were observed on either shoreline from the boat launch at Horse Thief Lake State Park to the boat exclusion buoys at the dam.

John Day Dam river sediment samples were collected at a cross river transect $~ 1.6 \mathrm{~km}$ upstream of the dam, $\sim 0.4 \mathrm{~km}$ upstream of the boat exclusion buoys. No beach sediment accumulation areas were observed on either shoreline from the boat launch at John Day River to the boat exclusion buoys at the dam.

McNary Dam river sediment samples were collected at a cross-river transect location, roughly $1.6 \mathrm{~km}$ upstream from the Oregon shore boat launch at McNary Dam. The McNary Dam sampling locations were used for routine sample collection by the Hanford Site Surface Environmental Surveillance Project and four cross-river locations were typically sampled (Poston et al. 2000). The names of the locations (beginning on the Oregon shore and moving to the Washington shore) are McNary OR Shore, McNary 1/3 OR Shore, McNary 2/3 OR Shore, and McNary WA Shore. Samples were not collected at McNary 1/3 OR Shore, because this study only required three sampling locations and McNary 2/3 OR Shore was used for the "mid-river" sample. Water samples were collected at the 2/3 OR Shore location. Beach sediment samples were collected on both the Oregon and Washington shores.

\subsection{Contaminants of Concern}

The radiological contaminants of concern for this study were strontium-90, gamma emitting radionuclides (primarily potassium-40, cobalt-60, cesium-137), europium, uranium, and plutonium. Radionuclides in river sediment have three sources: naturally occurring (potassium-40, uranium), atmospheric fallout (cobalt-60, strontium-90, cesium-137, uranium, plutonium), and potential Hanford releases (cobalt-60, strontium-90, cesium-137, europium-152, europium-154, europium-155, uranium-234, uranium-235, uranium-238, plutonium-238 and plutonium-239/240).

The chemical contaminants of concern were metals (Al, Sb, As, Ba, Be, Cd, Ca, Cr, Co, Cu, Fe, Pb, Mg, Mn, Ni, K, Se, Ag, Na, Tl, V, Zn and Hg), pesticides, PBCs, PAHs, semi-volatile organic compounds, simultaneously extracted metals/acid volatile sulfide (SEM/AVS; $\mathrm{Cd}, \mathrm{Cu}, \mathrm{Hg}, \mathrm{Ni}, \mathrm{Pb}$, and $\mathrm{Zn}$ ), and total organic carbon. In addition, samples from each location were analyzed for sediment grain size.

\subsection{Sample Collection}

Samples were collected according to the Surface Environmental Surveillance Procedures Manual (PNNL 2003). Samples of the upper sediment layer were collected with a petite Ponar dredge. The dredge has a

$235-\mathrm{cm}^{2}$ opening and collects sediment to a maximum depth of $15 \mathrm{~cm}$. The dredge has a pair of weighted 
jaws held open during descent to the sediment surface by tension from the retrieval cable to a catch bar. Upon contact with the sediment, the tension on the cable is released, the catch bar releases, and the overlapping jaws close. Upon retrieval, the tension on the cable keeps the jaws closed. A mesh screen with rubber flaps covers the upper portion of the dredge. The rubber flaps allow water to flow through the dredge during descent but close to minimize sediment losses during retrieval. Ponar dredges are suitable for most sediment types except for hard clays. Samples of beach sediment were collected using either the petite Ponar dredge or a large plastic scoop.

To allow for sufficient sample mass to meet the detection requirements for the various agencies and analytical tests, multiple deployments of the Ponar dredge were required. The sediment from each location was placed into a large plastic container lined with a clean plastic bag. The sediment was thoroughly mixed by hand and sample aliquots were transferred to containers appropriate for each agency's analytical requirements. At most locations, $\sim 6$ to $8 \mathrm{~kg}$ of sediment was collected. For most samples, doubled plastic bags provided a suitable container. Samples for SEM/AVS assays are extremely sensitive to air; thus, bottles for these samples were rapidly filled with sediment taken from a single Ponar dredge sample. All non-radiological sediment samples were placed into ice-filled coolers. Chain-ofcustody documentation and labels were provided by PNNL and samples were sealed with evidence tape. Geographic positioning system coordinates were collected for each location. Sediment samples were distributed among the groups according to the interests of the specific agencies and the availability of specialized analytical recourses. To aid in evaluating laboratory performance, multiple groups analyzed samples for some analytes (e.g., gamma-emitting radionuclides).

Water samples were collected according to the Surface Environmental Surveillance Procedures Manual (transect water-sampling procedure; PNNL 2003). All water samples were unfiltered and analyzed for strontium-90, and selected samples were analyzed for gamma-emitting radionuclides, isotopic uranium, and isotopic plutonium.

The quality assurance and quality control process for the sampling and analytical process is described in Appendix A. 


\subsection{Radiological and Chemical Analysis}

\subsubsection{Radiological}

DOH samples for radiological constituents were analyzed at their laboratory in Shoreline, Washington. Oregon DOE samples for gamma-emitting radionuclides were analyzed by the Oregon State University (Corvallis, Oregon). PNNL samples for radiological analysis were conducted by the Severn Trent Laboratories (Richland, Washington).

\subsubsection{Metals}

The Washington State Department of Ecology samples for metals were analyzed through their contract labs. Total metals were analyzed by U.S. Environmental Protection Agency (EPA) SW-846 method 6010. Mercury was analyzed separately by EPA SW-846 Method 7470. EPA Method SW-846 7196 was used for analysis of sediment samples for hexavalent chromium at the Washington State Department of Ecology's contract laboratory.

PNNL samples for metals and SEM/AVS were analyzed at the Sequim Marine Sciences Facility (Sequim, Washington) using the methods described in Patton and Crecelius (2001).

\subsubsection{Grain Size and Total Organic Carbon Assays}

PNNL samples for sediment grain size distributions were analyzed at the Sequim Marine Sciences Facility using an analytical subcontract with Columbia Analytical Services (Kelso, Washington). PNNL samples for total organic carbon content were analyzed by the Severn Trent Laboratories (Saint Louis, Missouri) using EPA SW 846 Method 9060.

\subsubsection{Pesticides}

Twenty-one pesticides were extracted using EPA SW 846 Method 3540C and analyzed using EPA SW 846 Method 8081A at the Washington State Department of Ecology’s contract laboratory.

\subsubsection{Polychlorinated Biphenyls (PCBs)}

The Washington State Department of Ecology samples for PCBs were extracted using EPA SW 846 Method 3540C and analyzed by EPA SW- 846 Method 8082 at their contract laboratory.

\subsubsection{Semi-Volatile Organic Compounds (Polycyclic Aromatic Hydrocarbons and Phthalates)}

The Washington State Department of Ecology's contract analytical laboratory extracted the sediments using EPA SW 846 Method 3540C and then analyzed the extracts for 16 polycyclic aromatic hydrocarbons (PAHs) and three phthalate ester plasticizers using EPA SW-846 Method 8270. 


\subsubsection{Bioassays (Sediment Toxicity Tests)}

The Microtox ${ }^{\circledR}$ and Daphnia IQ rapid toxicity tests for porewater (i.e., water associated with the sediment samples) derived from the sediment samples were performed by Aqua Survey, Inc. (Flemington, New Jersey) under subcontract to the Washington Department of Ecology. Toxicity tests were conducted for sediment samples collected from four dams on the lower Columbia River.

The Microtox® test measures reduction of bacterial luminescence (inhibition of luciferase) upon exposure to potential inhibitors, as an index of toxicity (Bulich 1979). The degree of light loss indicates the degree of toxicity. The test employs a lyophilized strain of marine luminescent bacteria, Vibrio fischeri, which is reconstituted. The toxicant concentration inhibiting luminescence by $50 \%$ [effective concentration; $\left(\mathrm{EC}_{50}\right)$ ] was determined for each sample with a control $(2 \% \mathrm{NaCl})$ and four sample dilutions $(5.62,11.2$, 22.5 , and $45 \% \mathrm{v} / \mathrm{v}$ ) after 5 - and 15 -minute exposure periods at $20^{\circ} \mathrm{C}$. These tests were conducted on both filtered $(0.2 \mu \mathrm{m})$ and non-filtered porewater samples.

The Daphnia IQ test measures inhibition of galactosidase, reducing in vivo cleavage of a fluorometric substrate, methylumbelliferyl (MUF) galactoside (Hayes et al. 1993; Janssen and Persoone 1993). Galactosidase is a vital enzymatic system in the aquatic invertebrate Daphnia magna. Inhibited enzymatic activity, measured by fluorescence, can be used as an index of toxicity. $\mathrm{EC}_{50}$ values were determined for each sample with a control (EPA moderately hard reconstituted water) and five sample dilutions $(6.25,12.5,25,50$, and $100 \% \mathrm{v} / \mathrm{v})$ after a 1-hour exposure to the sample at $20^{\circ} \mathrm{C}$, followed by an additional 15-minute exposure to the MUF galactoside substrate. These tests were conducted in triplicate using non-filtered sediment porewater samples.

\subsection{Results and Discussion}

\subsection{Columbia River and Beach Sediment}

The following section describes the results for Columbia River sediment and Columbia shoreline beach sediment that were analyzed for radionuclides, chemicals, and sediment grain size distributions.

\subsubsection{Radiological Results}

Sediment samples collected by the DOH and PNNL were analyzed for gamma-emitting isotopes, uranium, plutonium, and strontium-90. Samples collected for the Oregon DOE were analyzed for gamma-emitting isotopes. All results are reported on a dry weight basis and are presented in Appendix B, Table B.1.

The field team attempted to collect samples at all scheduled locations; however, the absence of sediment at several locations made it impossible to collect all samples. Locations where sediment samples were successfully collected are listed in Table 2. 
Table 2. Locations Where Sediment Samples were Successfully Collected

\begin{tabular}{||l|c|c|c|c|c||}
\hline \multicolumn{1}{|c|}{ Location } & $\begin{array}{c}\text { Oregon } \\
\text { Beach }\end{array}$ & $\begin{array}{c}\text { Oregon Near } \\
\text { Shore }\end{array}$ & Mid-River & $\begin{array}{c}\text { Washington } \\
\text { Near Shore }\end{array}$ & $\begin{array}{c}\text { Washington } \\
\text { Beach }\end{array}$ \\
\hline \hline Bonneville & $\mathrm{X}$ & $\mathrm{X}$ & & & \\
\hline The Dalles & & $\mathrm{X}$ & & $\mathrm{X}$ & \\
\hline John Day & $\mathrm{X}$ & $\mathrm{X}$ & $\mathrm{X}$ & \\
\hline McNary & $\mathrm{X}$ & $\mathrm{X}$ & $\mathrm{X}$ & $\mathrm{X}$ & $\mathrm{X}$ \\
\hline $\begin{array}{l}\mathrm{X}=\text { Sediment was collected. } \\
\text { Blanks = No sediment was available. }\end{array}$ \\
\hline
\end{tabular}

In general, radionuclides of Hanford origin would be indicated by a particular trend in that nuclide's concentrations in river sediment. Material of Hanford origin is likely indicated by a rise in concentration above the concentration measured at the Priest Rapids Dam background location, peaking at the McNary Dam pool (closest downstream sediment reservoir to the Hanford Site), and gradually declining in the lower reservoirs due to dilution from other sediment sources.

In the below analysis, the concentrations of radionuclides in beach sand have been excluded from the discussion because the mechanisms for concentrating radionuclides in the sand might be different from those of river sediment. The radionuclide concentrations for beach sand samples are recorded in Appendix B, Table B.1.

No federal or state freshwater sediment criteria for radionuclides are available to assess the sediment quality of the Columbia River (EPA 822-R-96-001).

\subsubsection{Potassium-40 (130,000,000 yr half-life)}

Naturally-occurring potassium-40 was present at levels above detection in all sediment samples taken by each agency. The highest concentration in sediment from the river was $18.7 \mathrm{pCi} / \mathrm{g}$ (Oregon DOE) near the Oregon shore at the John Day Dam and the lowest concentration, 8.2 pCi/g (DOH), was found in Bonneville Dam sediment near the Oregon shore (Figure 2). Background sediments collected upriver from the Priest Rapids Dam contained $12.3 \mathrm{pCi} / \mathrm{g}$ and $12.2 \mathrm{pCi} / \mathrm{g}$ in the sediment from the Grant County and Yakima County sides of the river, respectively. Generally the concentration of potassium-40 remained constant downriver with no discernable cross-river pattern.

\subsubsection{Cobalt-60 (5.3 yr half-life)}

Cobalt-60 was detected in some of the sediment samples collected. All three agencies analyzed sediment samples for cobalt-60. The highest concentration of cobalt-60, $0.08 \mathrm{pCi} / \mathrm{g}$ (Oregon DOE) was found for sediment from the McNary pool (McNary 2/3 OR Shore; Figure 3). Cobalt-60 in sediment samples from the background location at Priest Rapids Dam were below a nominal detection limit of $0.02 \mathrm{pCi} / \mathrm{g}$. No particular trend was seen in concentrations downstream or laterally across the impoundments. 

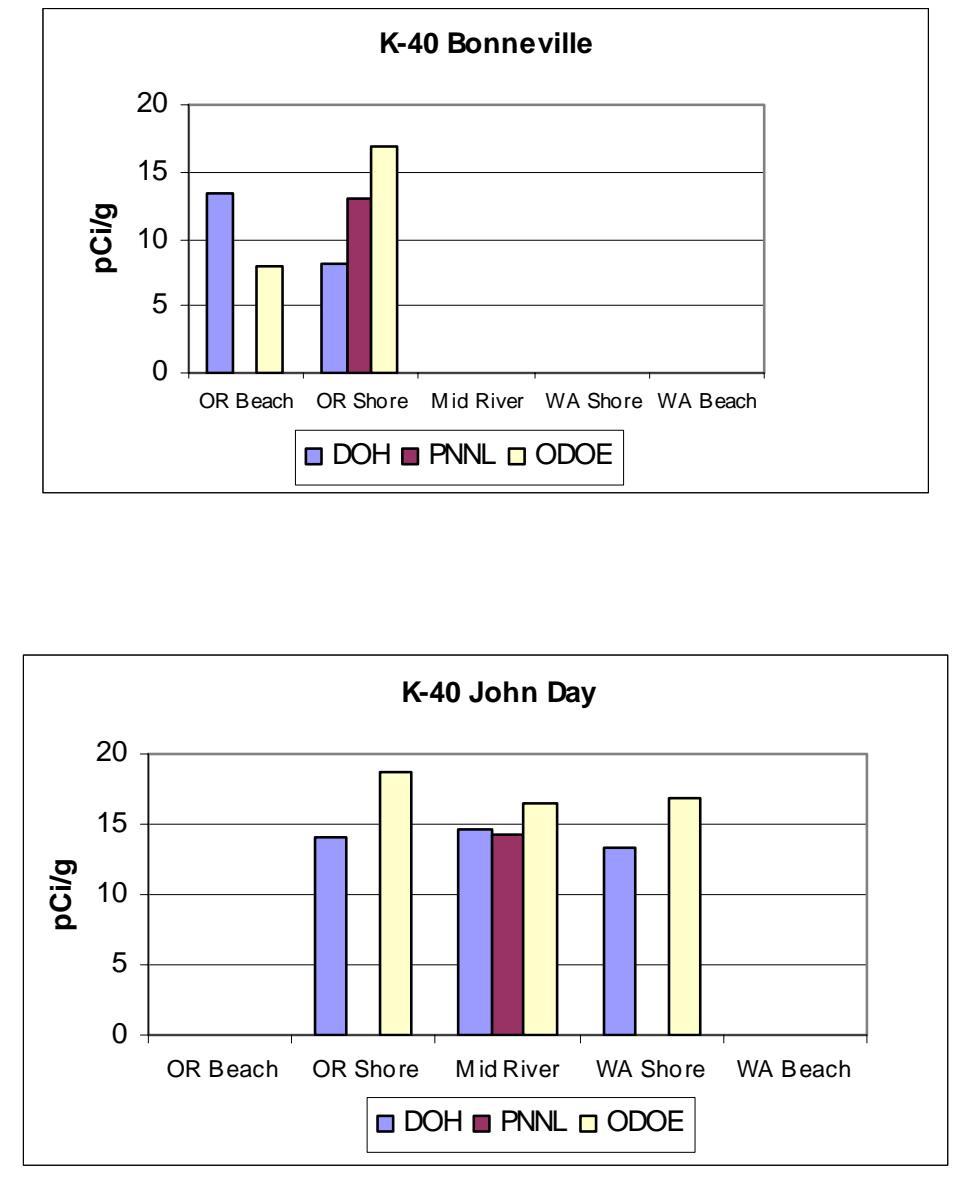
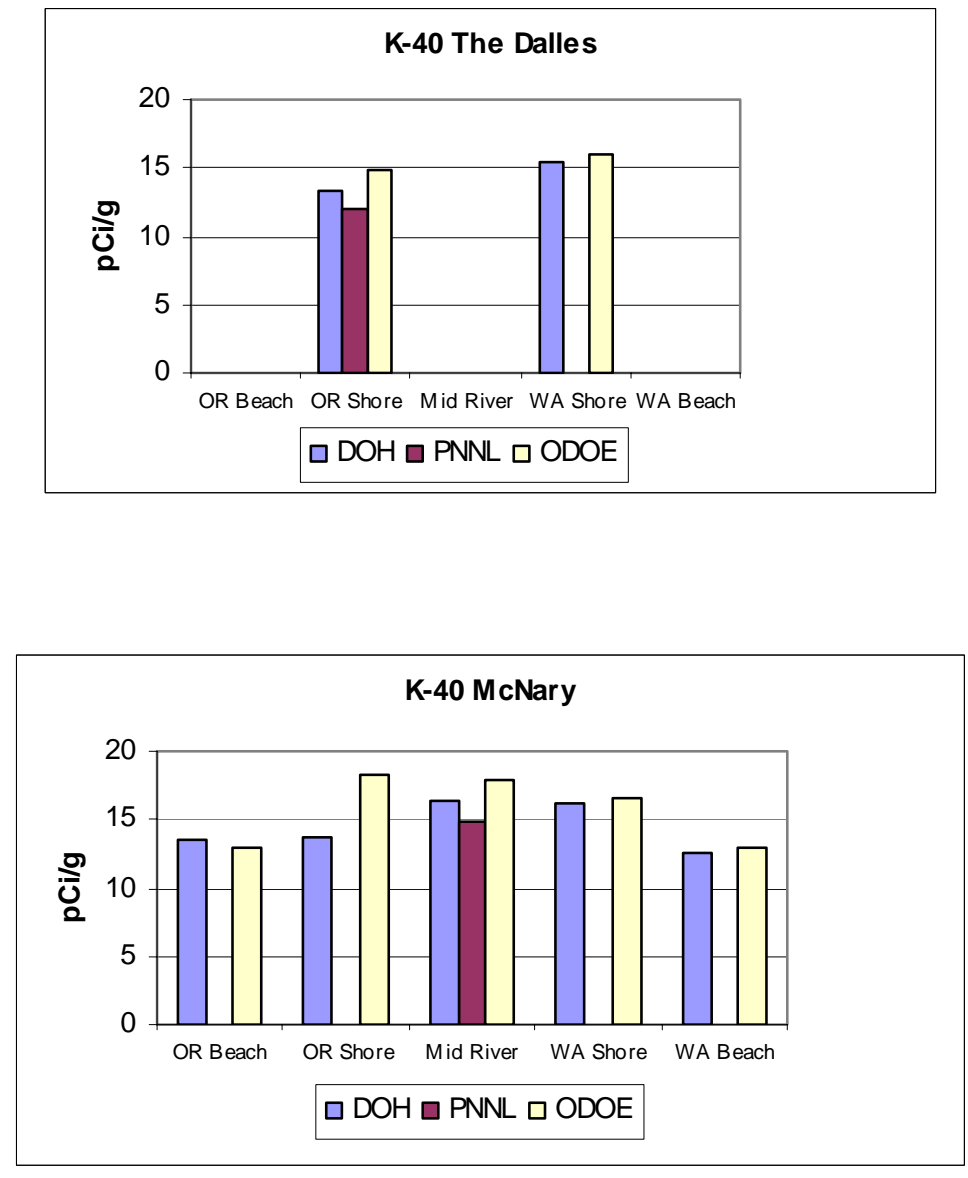

Figure 2. Concentrations of Potassium-40 in Columbia River Sediment, 2003. All values for potassium-40 were above detection limits. Potassium-40 concentrations for sediment from the pool upstream from Priest Rapids Dam were $12.2 \pm 1.6$ and $12.3 \pm 1.6$ $\mathrm{pCi} / \mathrm{g}(\mathrm{PNNL})$. 

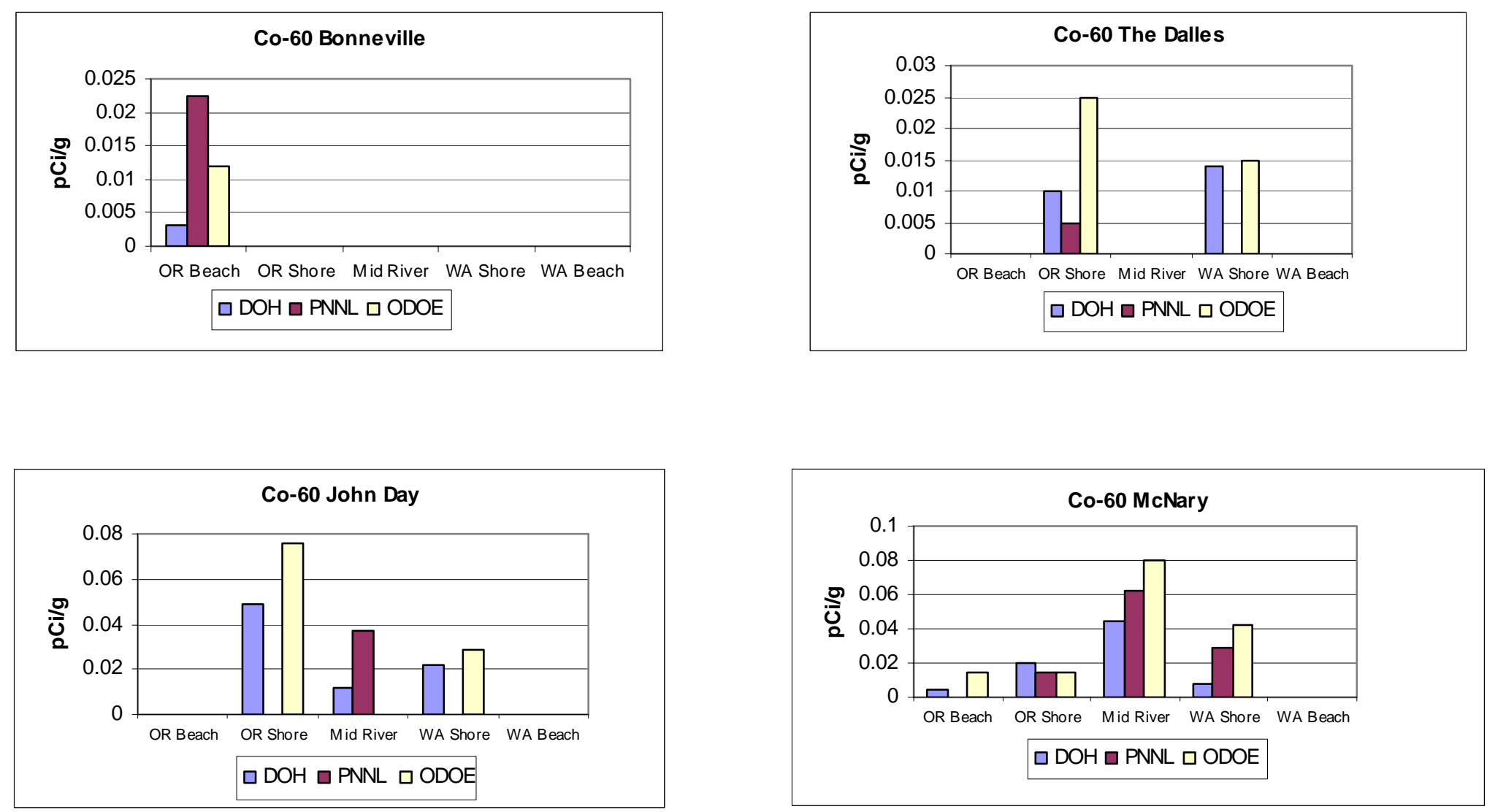

Figure 3. Concentrations (pCi/g dry wt.) of Cobalt-60 in Columbia River Sediment, 2003. All PNNL values were below a nominal detection limit of $0.06 \mathrm{pCi} / \mathrm{g}$, except for McNary Dam mid-river. Some DOH values were below a nominal detection limit of $0.01 \mathrm{pCi} / \mathrm{g}$. All ODOE results were greater than the associated 3-sigma counting errors. Cobalt-60 concentrations for sediment from the pool upstream from Priest Rapids Dam were below the detection limit; $-0.003 \pm 0.012$ and $0.004 \pm 0.011$ $\mathrm{pCi} / \mathrm{g}(\mathrm{PNNL})$. 


\subsubsection{Strontium-90 (29.1 yr half-life)}

Strontium-90 was detected in most of the sediment samples analyzed by DOH, whereas most sediment samples analyzed by PNNL were reported as undetected. The DOH had a lower limit of detection for strontium-90 in sediment samples than PNNL. The highest detectable concentration of strontium-90 $(0.032 \mathrm{pCi} / \mathrm{g}, \mathrm{DOH})$ in sediment was found on the Oregon side of the John Day Dam pool. The background samples analyzed by PNNL from Priest Rapids contained $0.00326 \pm 0.021$ and $0.0104 \pm$ $0.024 \mathrm{pCi} / \mathrm{g}$ of strontium-90 (Figure 4), with both values reported as undetected by the analytical laboratory. Again, no particular trend was seen in concentrations downstream or laterally across the impoundments.

The Hanford Site Surface Environmental Surveillance Project and the Washington Department of Health collect annual sediment samples from Priest Rapids Dam, the Hanford Reach, and McNary Dam sediment basins. Strontium-90 concentrations were below the detection limits for most sediment samples for years 2000 to 2002 (Poston et al. 2003), with no obvious differences in concentrations for strontium-90 between upriver and downriver locations.

\subsubsection{Cesium-137 (30 yr half-life)}

Cesium-137 was present at levels above detection in all of the river sediment samples. Values for cesium-137 ranged from 0.094 (DOH, Bonneville OR Shore) to $0.63 \mathrm{pCi} / \mathrm{g}$ (ODOE, John Day OR Shore) (Figure 5). There was no discernable pattern to the distribution of cesium-137 laterally across the river. Typically the concentrations of cesium-137 in sediment for the lower Columbia River were higher than the background location, indicating a possible Hanford contribution. The background concentration of cesium-137 in river sediment at the Priest Rapids Dam pool ranged from 0.285 to 0.324 pCi/g.

\subsubsection{Europium-152 (13.3 yr half-life)}

Europium-152 was detected in river sediment by PNNL and DOH. Europium-152 concentrations detected downstream from Hanford ranged from below detectable limits on the Oregon side of McNary Dam to $0.286 \mathrm{pCi} / \mathrm{g}$ mid-river (2/3 OR Shore) at the McNary Dam (Figure 6). The background samples analyzed by PNNL at the Priest Rapids Dam pool ranged from 0.009 to $0.026 \mathrm{pCi} / \mathrm{g}$, with both values reported as undetected by the analytical laboratory. In general, the concentrations of europium-152 downstream from the Hanford Site were slightly elevated, indicating a possible Hanford contribution.

\subsubsection{Total Uranium [Sum of U-234 (240,000 yr half-life), U-235 (700,000,000 yr half-life), and U-238 (4,500,000,000 yr half-life)]}

Isotopic uranium was measured in all sediment samples at levels above detection for both $\mathrm{DOH}$ and PNNL samples. The majority of the chemical mass of uranium was uranium-238. On an activity basis, the concentrations of uranium-234 and uranium-238 were similar. No enrichment of uranium-235 was observed, which would have indicated a possible Hanford signature. For river sediment the highest concentration of total uranium, $3.56 \mathrm{pCi} / \mathrm{g}(\mathrm{DOH})$, was found near the Washington shore of The Dalles Dam pool (Figure 7). The lowest total uranium concentration, $0.9 \mathrm{pCi} / \mathrm{g}(\mathrm{DOH})$, was found near the Oregon shore of the Bonneville impoundment. The concentration of total uranium in river sediment upriver from the pool at Priest Rapids Dam ranged from 1.3 to $1.4 \mathrm{pCi} / \mathrm{g}$ (PNNL data from Appendix B, 
Table B.1). Total uranium concentrations downstream were fairly constant. For most samples analyzed for total uranium, the values for the DOH were higher than the values reported by PNNL. This difference in total uranium concentrations may be the result of differences in the extraction processes.

\subsubsection{Isotopic Plutonium [Plutonium-238 (87.7 yr half-life) and Plutonium-239/240 (24,000 yr and 6,500 yr half lives)]}

DOH and PNNL analyzed sediment samples for isotopic plutonium. Plutonium-238 concentrations were below DOH's low limit of detection $(0.03 \mathrm{pCi} / \mathrm{g})$ for all samples. Plutonium-238 was reported above the detection limit for 3 of 5 samples analyzed by PNNL, with detected values ranging from 0.00027 to $0.00053 \mathrm{pCi} / \mathrm{g}$. The highest concentration of plutonium-238 was reported for the mid-river sample at McNary Dam (2/3 from Oregon shore). The maximum concentration of plutonium-238 was detected in river sediment upriver from Priest Rapids Dam 0.00064 pCi/g, which was slightly higher that the maximum value measured for McNary Dam.

Plutonium-239 and plutonium-240 are not resolved by the analytical method and are reported as combined plutonium-239/240 activity. Plutonium-239/240 was found in river sediment at levels above the detection limits for most of the samples collected. The highest concentration of plutonium-239/240 was $0.049 \mathrm{pCi} / \mathrm{g}(\mathrm{DOH})$ and was found in river sediment near the Washington shore of The Dalles Dam pool (Figure 8). Plutonium-239/240 levels in sediment at Priest Rapids Dam ranged from 0.0095 to $0.0116 \mathrm{pCi} / \mathrm{g}$.

At all locations with detectable values, plutonium-238 concentrations were typically an order of magnitude below the plutonium-239/240 concentrations. 

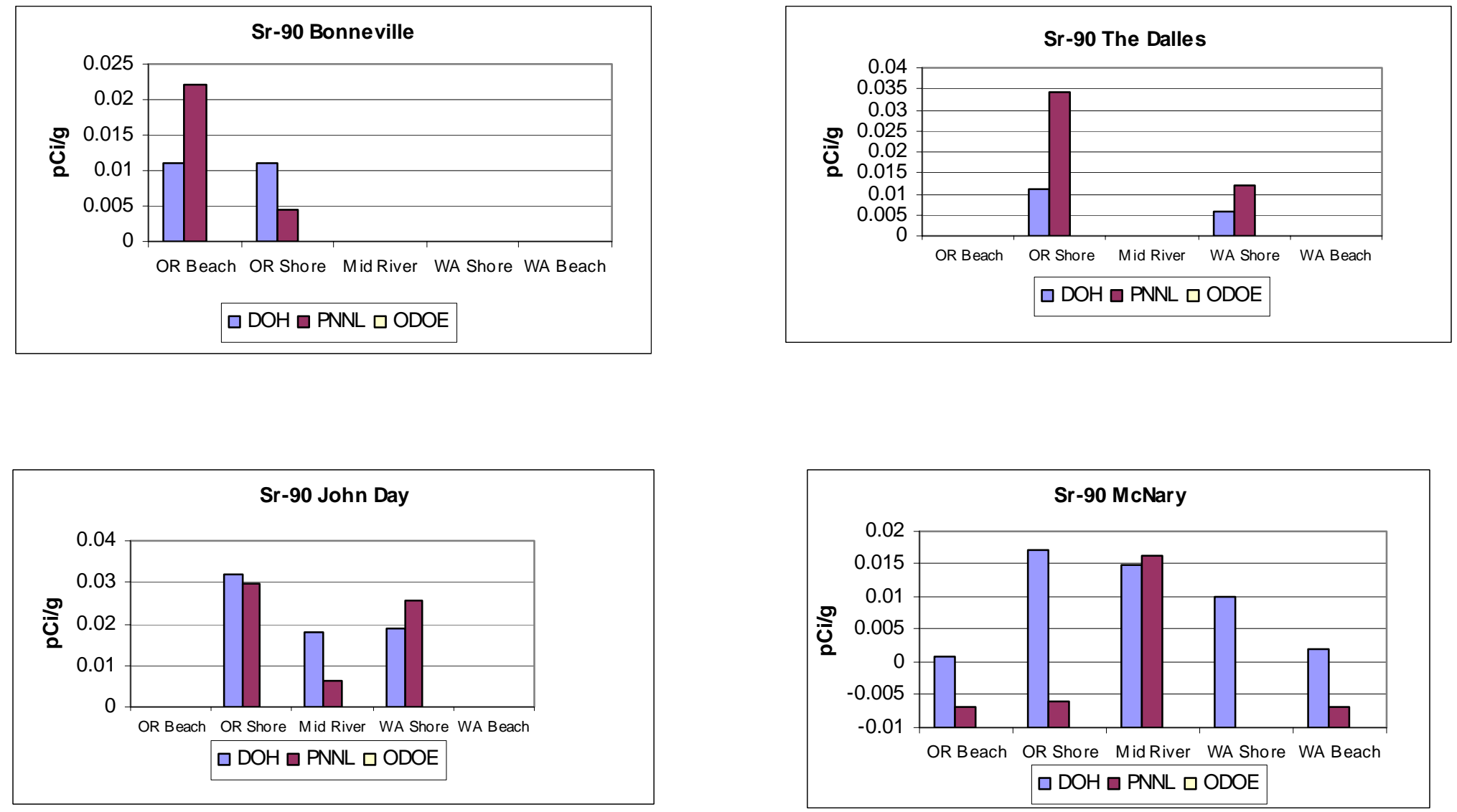

Figure 4. Concentrations of Strontium-90 in Columbia River Sediment, 2003. All DOH results for river sediment were above the detection limit. All PNNL results were below a nominal detection limit of $0.04 \mathrm{pCi} / \mathrm{g}$; except for John Day OR shore which had a value of $0.030 \pm 0.018 \mathrm{pCi} / \mathrm{g}$. Strontium-90 concentrations for sediment by PNNL from the pool upstream from Priest Rapids Dam were below the detection limit; $0.0033 \pm 0.021$ and $0.010 \pm 0.024 \mathrm{pCi} / \mathrm{g}$. 

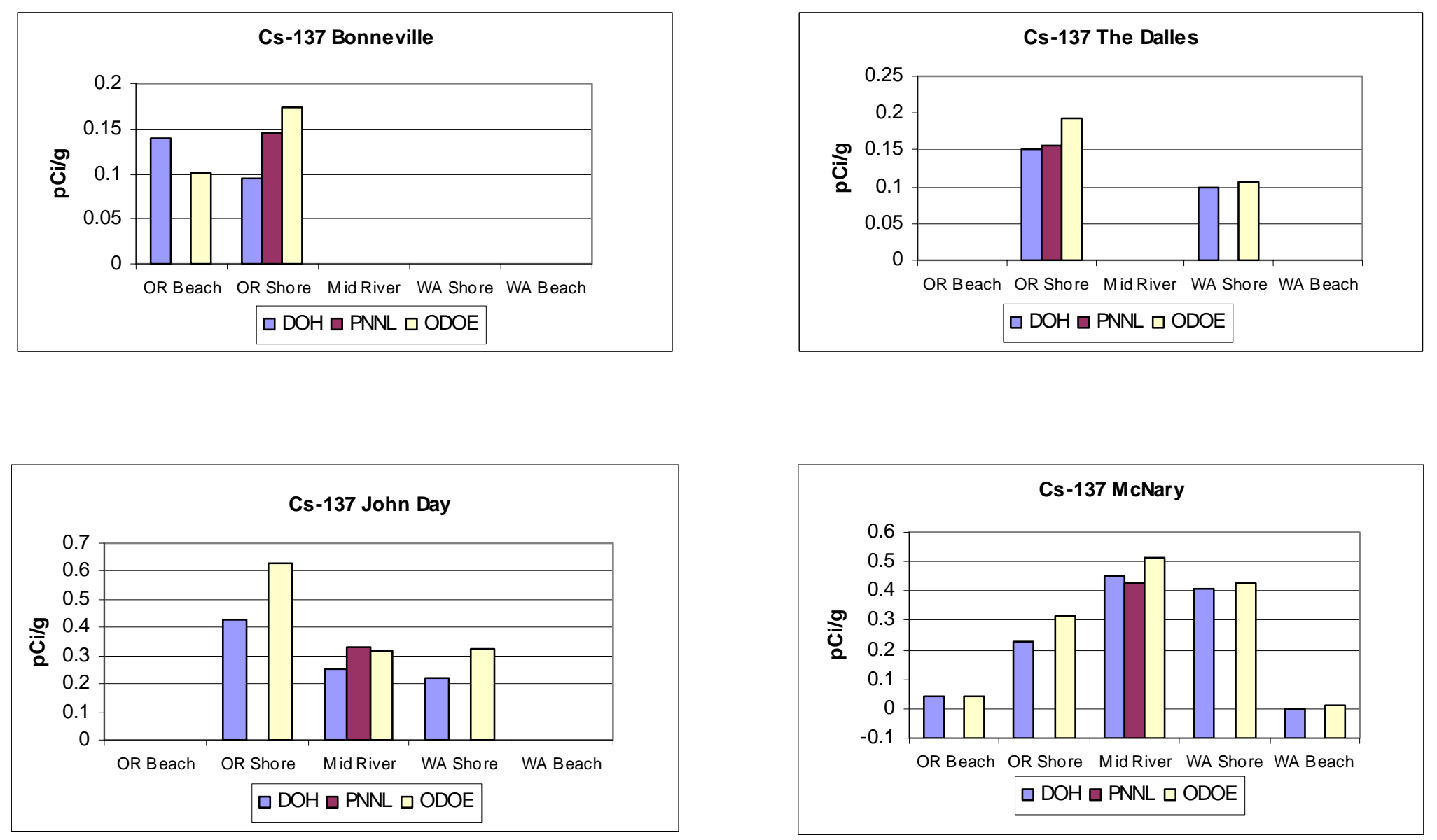

Figure 5. Concentrations of Cesium-137 (pCi/g dry wt.) in Columbia River Sediment, 2003. All values for river sediment were above detection limits. Cesium-137 concentrations for sediment from the pool upstream from Priest Rapids Dam were $0.285 \pm$ 0.041 and $0.324 \pm 0.048 \mathrm{pCi} / \mathrm{g}(\mathrm{PNNL})$. 

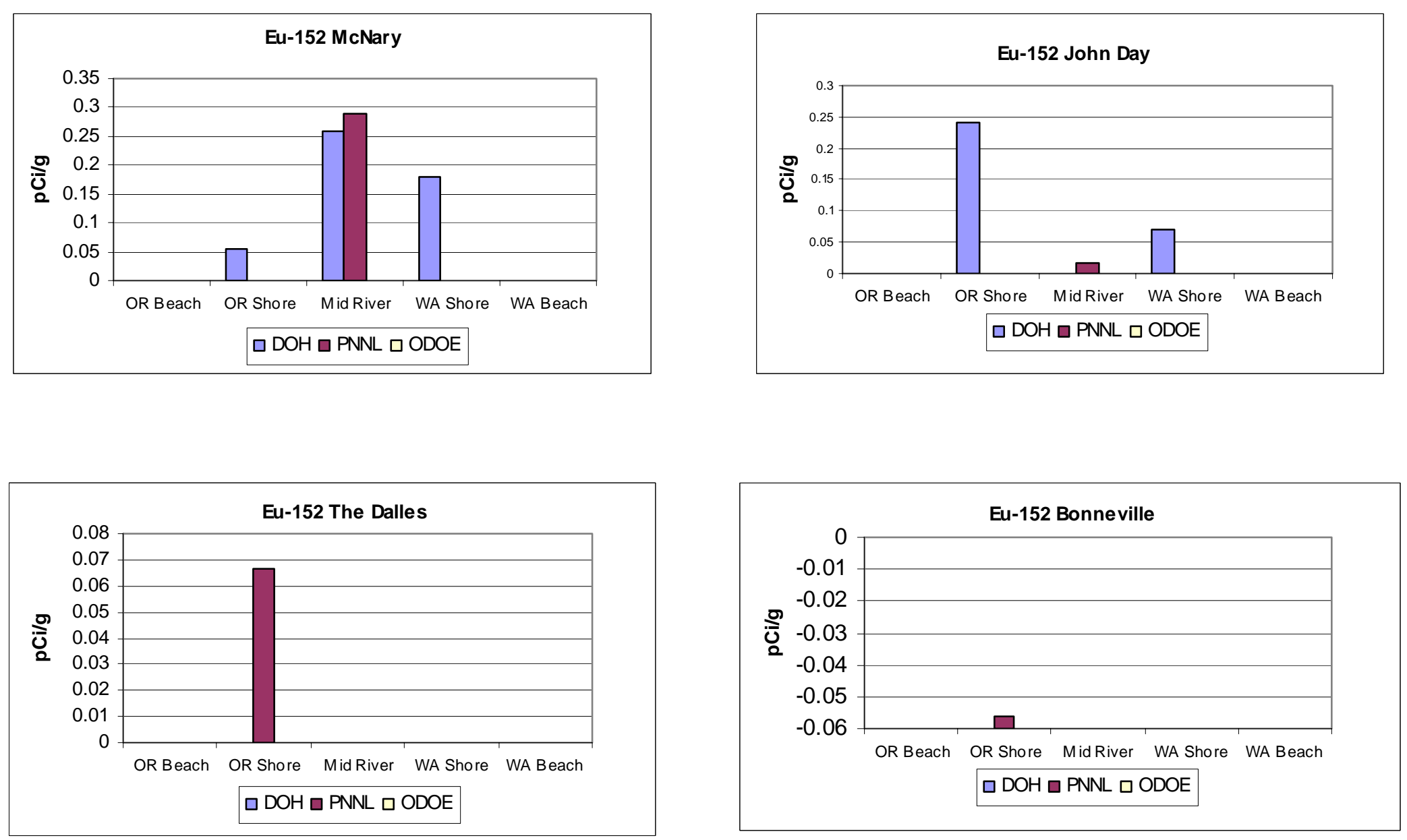

Figure 6. Concentrations of Europium-152 (pCi/g dry wt.) in Columbia River Sediment, 2003. All DOH values were above the detection limit. All PNNL values were below a nominal detection limit of $0.15 \mathrm{pCi} / \mathrm{g}$, except for McNary Dam mid-river. Europium-152 concentrations for sediment from the pool upstream from Priest Rapids Dam were below the detection limit with values of $0.0095 \pm 0.027$ and $0.026 \pm 0.032 \mathrm{pCi} / \mathrm{g}$ (PNNL). 

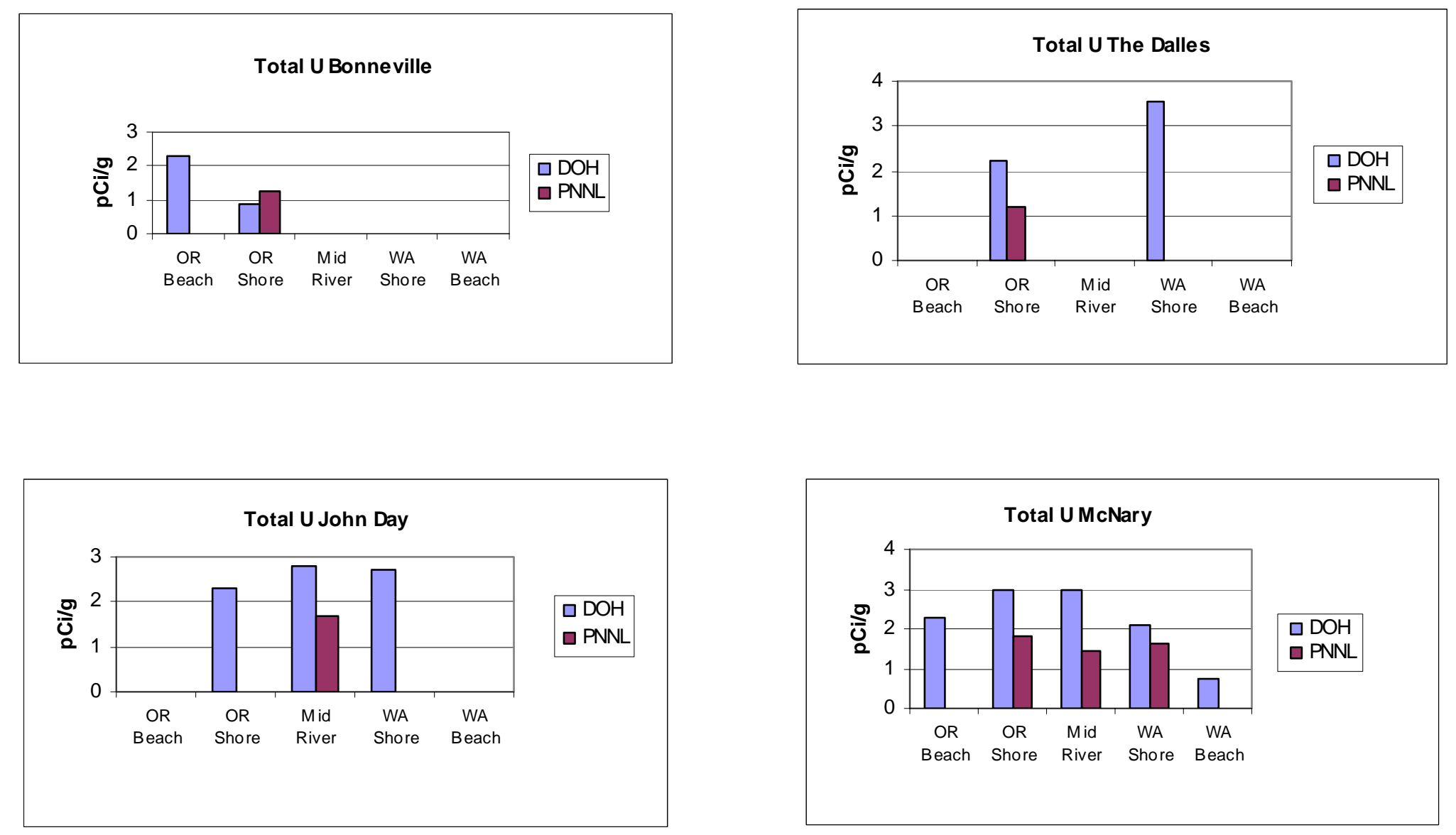

Figure 7. Concentrations (pCi/g dry wt.) of Total Uranium (U-234 + U-235 + U-238) in Columbia River Sediment, 2003. All values for river sediment were above detection limits. Total uranium concentrations for sediment from the pool upstream from Priest Rapids Dam were $1.26 \pm 0.16$ and $1.41 \pm 0.016$ pCi/g (PNNL). 


\subsubsection{Chemical Results}

Sediment samples collected by the Washington State Department of Ecology and PNNL were analyzed for organic compounds (pesticides, PCBs, and semi-volatiles), metals (including hexavalent chromium), SEM/AVS, sediment grain size distributions, and total organic carbon content. In addition, sediment porewater was used to conduct two bioassay evaluations.

In 2002, the Washington State Department of Ecology embarked on a project to identify, update, and ultimately select freshwater sediment quality values (SQVs) for use in the Washington State Department of Ecology's sediment management programs. The first phase of this effort was completed in December 2002 (SAIC and Avocet 2002) and included compilation of existing freshwater SQVs in North America and an assessment of their reliability in predicting effects in Washington State. The results of this work indicated that additional Phase II work was needed to update existing freshwater apparent effects thresholds (AETs) and calculate more reliable SQVs for Washington State, as none of the existing guidelines were adequately predictive of toxicity in the Washington State data set. In 2003, the Washington State Department of Ecology proposed freshwater sediment quality criteria for selected chemical contaminants for Washington State (Michelsen 2003). Where applicable, sediment concentrations will be compared to the proposed sediment quality criteria. The Washington State proposed SQVs are provided for metals in Appendix B, Table B.2 and for semi-volatile organics in Appendix B, Table B.5.

\subsubsection{Metals}

Detectable amounts of most metals were found in river and beach sediment samples analyzed by WDOE and PNNL (Figure 9 and Appendix B, Table B.2) The metal concentrations reported for this study were similar to previously reported values (Patton and Crecelius 2001; Poston et al. 2003). Median concentrations of cadmium, arsenic, nickel, copper, lead, chromium, and zinc were highest for sediment collected at the Priest Rapids impoundment. Compared to Priest Rapid Dam sediment, the median concentrations of mercury, silver, selenium, antimony, and thallium were generally higher for the downriver pools, particularly for samples collected at the John Day Dam pool. There was no indication of a unique Hanford Site contribution for metals in Columbia River sediment. Median sediment concentrations for antimony, cadmium, silver (John Day Dam only), and zinc were above the proposed Washington State sediment quality criteria (Michelsen 2003). 

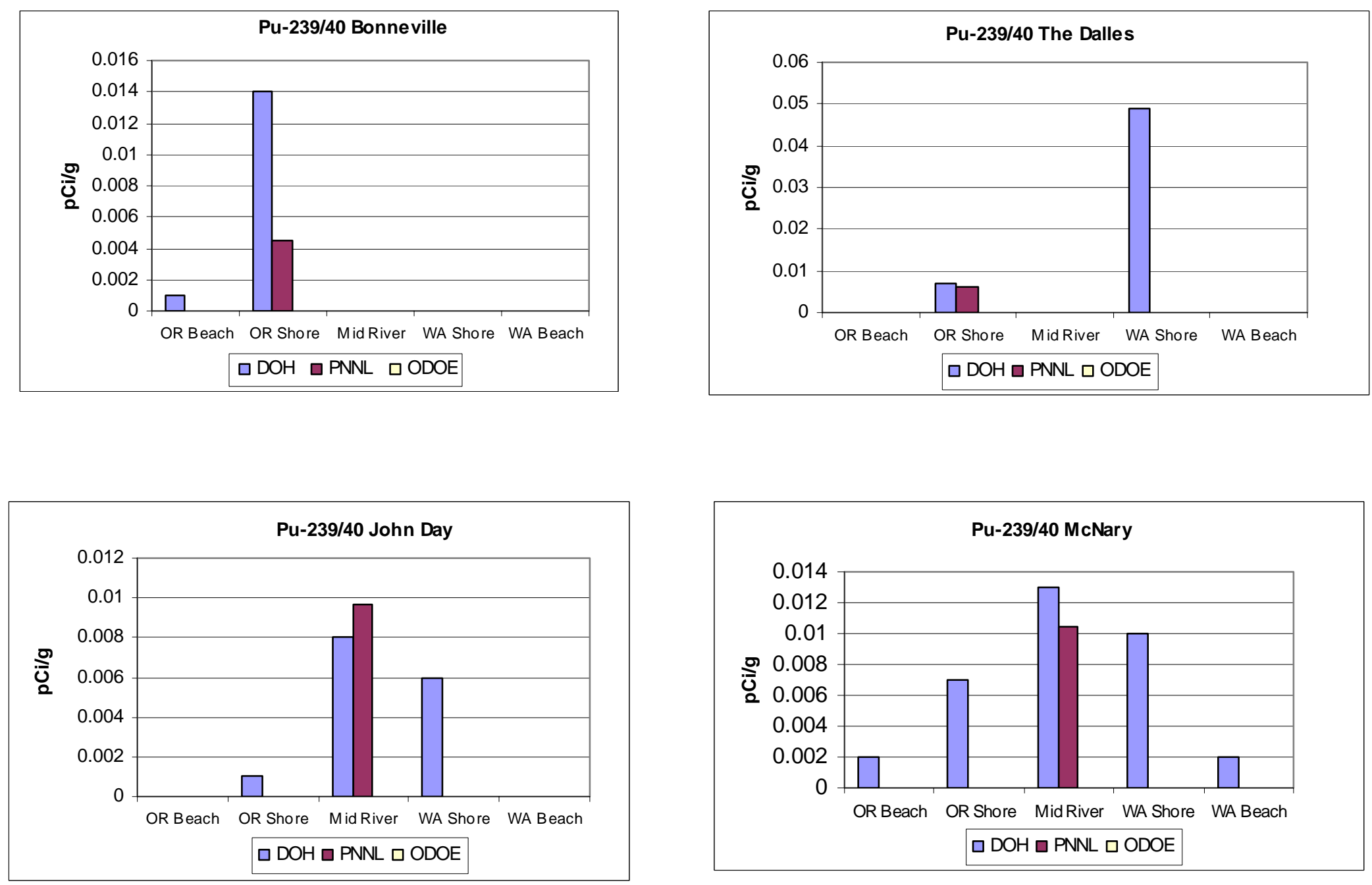

Figure 8. Concentrations (pCi/g dry wt.) of Plutonium-239/240 in Columbia River Sediment, 2003. All PNNL values were above the detection limit. Some DOH results were below a nominal detection limit of $0.006 \mathrm{pCi} / \mathrm{g}$. Plutonium-239/240 concentrations for sediment from the pool upstream from Priest Rapids Dam were $0.00956 \pm 0.0023$ and $0.0116 \pm 0.0023$ pCi/g (PNNL). 

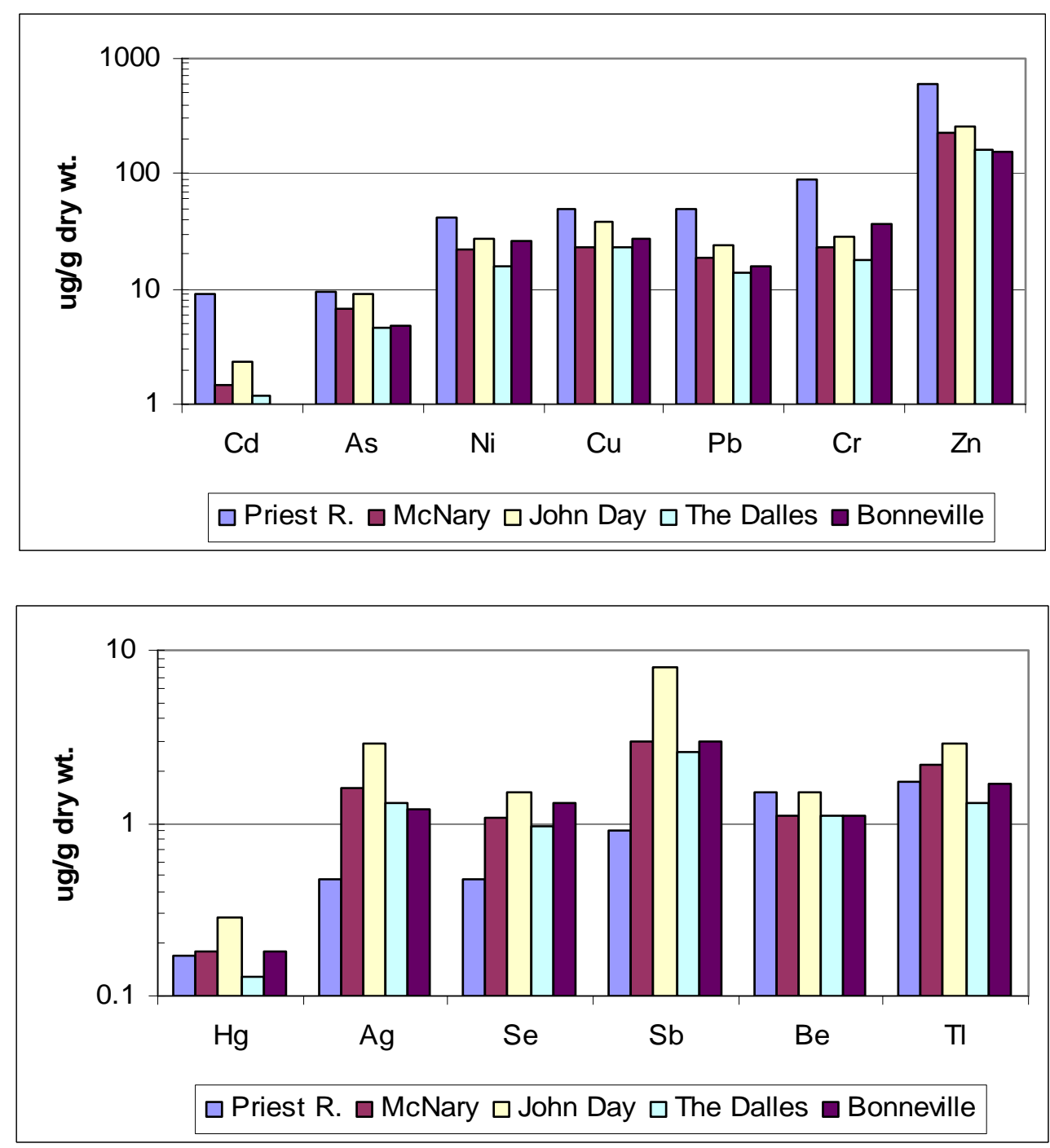

Figure 9. Median Concentrations ( $\mu \mathrm{g} / \mathrm{g}$ dry wt.) of Metals in Columbia River Sediment (Combined WDOE and PNNL Results).

The Washington State Department of Ecology sediment samples that were analyzed for hexavalent chromium were all below the detection limit of $2 \mu \mathrm{g} / \mathrm{g}$ dry wt.

\subsubsection{Simultaneously Extracted Metals/Acid Volatile Sulfide (SEM/AVS)}

Columbia River sediments were analyzed for SEM/AVS. This analysis involves a cold acid extraction of the sediments followed by analysis for sulfide and metals. The molar ratios of SEM metals to the acid volatile sulfide are an indicator of potential sediment toxicity (DeWitt et al. 1996; Hansen et al. 1996). Acid volatile sulfide is an important binding phase for divalent metals (i.e., metals with a valance state of $2+$, such as $\mathrm{Pb}^{2+}$ ) in sediment. Metal sulfide precipitates are typically very insoluble; this limits the 
amount of dissolved metal available in the sediment porewater. For an individual metal, when the amount of AVS exceeds the amount of the metal (i.e., the SEM/AVS molar ratio is below one), the metal concentration in the sediment porewater will be low because of the limited solubility of the metal sulfide. For a suite of divalent metals, the sum of the SEMs must be considered, with the assumption that the metal with the lowest solubility will be the first to combine with the AVS.

The concentrations of SEM metals and AVS are provided in units of $\mu$ mol of analyte per gram of sediment ( $\mu \mathrm{mol}$ analyte/g). The molar-based units are required to directly compare the pool of available sulfide (AVS) to the pool of divalent metals (SEM). Conversion to the more typically reported $\mu \mathrm{g} / \mathrm{g}$ unit is made using Equation (1) or $\mu \mathrm{mol} / \mathrm{g} \times$ molecular weight $=\mu \mathrm{g} / \mathrm{g}$ (Note: molecular weight $=\mathrm{g} / \mathrm{mol}=$ $\mu \mathrm{g} / \mu \mathrm{mol})$.

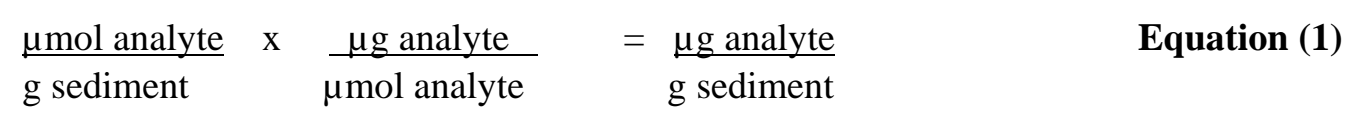

The average SEM/AVS results for the sediment collected during 2003 in the reservoirs upriver from Priest Rapids, McNary, John Day, The Dalles, and Bonneville dams are shown in Figure 10 and the individual results are provided in Appendix B, Table B.3. In general, the results were similar to values reported by Patton and Crecelius (2001) for sediment analyzed from upriver of Priest Rapids Dam and McNary Dam. For all locations, zinc was the primary SEM metal present. AVS concentrations ranged from 0.05 to 8.4 $\mu \mathrm{mol} / \mathrm{g}$. Overall, sediment from the McNary Dam reservoir had the lowest concentrations of AVS, with an average value of $1.4 \mu \mathrm{mol} / \mathrm{g}$. The SEM/AVS average molar ratios for sediment from the Priest Rapids Dam and McNary Dam reservoirs were above 1.0, indicating a potential for some dissolved metals to be present in the sediment porewater. Samples from John Day, The Dalles, and Bonneville Dams had average SEM/AVS molar ratio below one (i.e., low potential for dissolved metals in sediment porewater). 


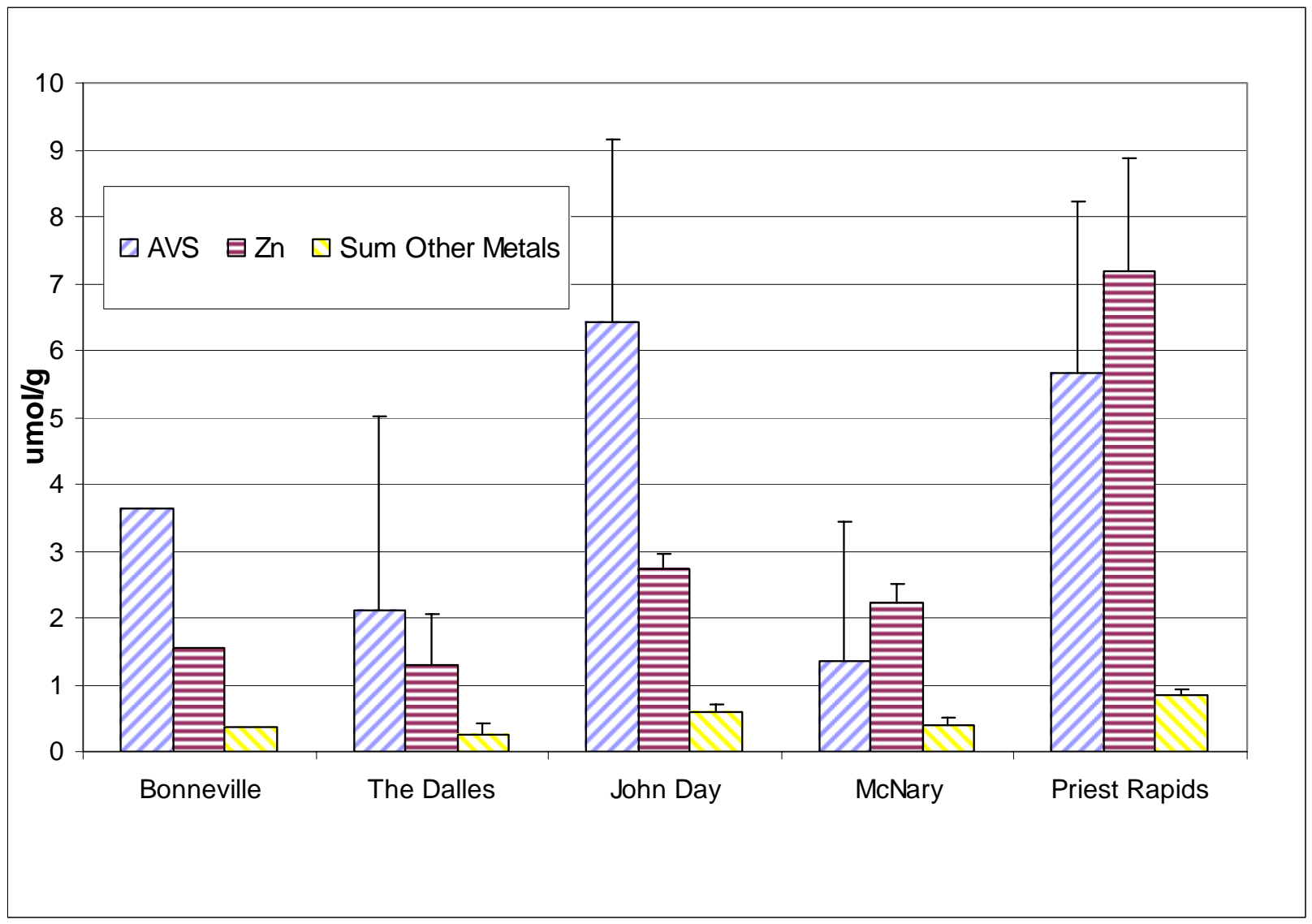

Figure 10. Average ( \pm 1 Standard Deviation) Simultaneously Extracted Metals/Acid Volatile Sulfide (SEM/AVS) Concentrations in Columbia River Sediment. Sum of Other Metals are Cadmium, Copper, Mercury, Nickel, and Lead.

An apportionment of AVS by divalent metals according to solubility values revealed that sufficient AVS should exist in all locations to limit the porewater concentrations of cadmium, copper, lead, and mercury. However, for Priest Rapids Dam and McNary Dam sediment, the average zinc concentrations were higher than the available mean AVS pool, indicating the potential for zinc and possibly other dissolved metals to be present in the sediment porewater.

\subsubsection{Pesticide, Semi-Volatile Organics, and PCB Results}

Twenty-one organochlorine pesticides were analyzed by gas chromatography using electron capture detection. Pesticide classes included hexachlorocyclohexanes, chlordanes, DDT-group, dieldrin, aldrin, endosulfanes, and toxaphene. These compounds were below the method detection limit for all samples (Appendix B, Table B.4).

Analysis was conducted for 71 semi-volatile compounds by gas chromatography using mass spectrometry detection. Compounds include polycyclic aromatic hydrocarbons, chlorinated hydrocarbons and pesticides, phthalate esters, organophosphate esters, nitrosamines, halogenated ethers, aldehydes, ethers, 
ketones, anilines, pyridines, quinolines, aromatic nitrocompounds, nitrophenols, and phenols. All compounds were below the method detection levels at all locations (Appendix B, Table B.5).

Sediment samples were analyzed for PCBs as seven Aroclor mixtures using gas chromatography with electron capture detection. All compounds were below the method detection level for all sites sampled. Appendix B, Table B.5)

The analytical detection limits for sediment samples analyzed for semi-volatile organic compounds were below the proposed Washington State sediment quality limits (Appendix B, Table B.5).

\subsubsection{Sediment Grain Size Results}

Sediment samples from all locations were analyzed for sediment grain size distributions and the results are provided in Appendix B, Table B.6. Sediment size fractions were evaluated for gravel ( $>2.0 \mathrm{~mm})$, very coarse sand $(1.0-2.0 \mathrm{~mm})$, coarse sand $(0.5-1.0 \mathrm{~mm})$, medium sand $(0.25-0.5 \mathrm{~mm})$, fine sand $(0.125-0.25 \mathrm{~mm})$, very fine sand $(0.0625-0.125 \mathrm{~mm})$, silt $(0.002-0.0625 \mathrm{~mm})$, and clay $(<0.002 \mathrm{~mm})$.

River sediment samples were similar at most locations with the majority of the mass composed of silt, with some contribution from very fine sand and clay (Figure 11). The notable exception was The Dalles Dam sediment collected on the Washington side of the river, which was composed primarily of medium, fine, and very fine sand. John Day Dam had a very uniform distribution of sediment size for all river sediment locations. River sediment from McNary Dam and The Dalles Dam revealed a shift in the sediment distribution to coarser sediment size for the samples collected on the Washington side of the river. Sediment grain size distributions for this study were similar to previously reported values at McNary Dam (Blanton et al. 1995; Patton and Crecelius 2001).

For locations where shoreline beach sediment samples were collected (McNary Dam and Bonneville Dam), the majority of the sediment mass was composed of medium and coarse sand (Figure 12).

\subsubsection{Total Organic Carbon Content}

The total organic carbon (TOC) content of Columbia River sediment samples are shown in Figure 13 and presented in Appendix B, Table B.7. For most river sediment locations, the TOC content ranged from 5,460 to $16,200 \mathrm{mg} / \mathrm{kg}$; however, the sample collected on the Washington side of The Dalles Dam had a low TOC value of 1,490 mg/kg. TOC content showed considerable variation within each reservoir, with McNary Dam and The Dalles Dam having lower values for the samples collected on the Washington side of the river. TOC values at John Day Dam were highest at mid-river (maximum TOC value for the entire study) with concentrations decreasing slightly for the samples collected on the Washington and Oregon sides of the river. The TOC concentrations of Columbia River beach sediment were low for all samples collected, with values ranging from 214 to $1,110 \mathrm{mg} / \mathrm{kg}$. In general, the locations with higher TOC contents typically were composed of finer grain sediment. 

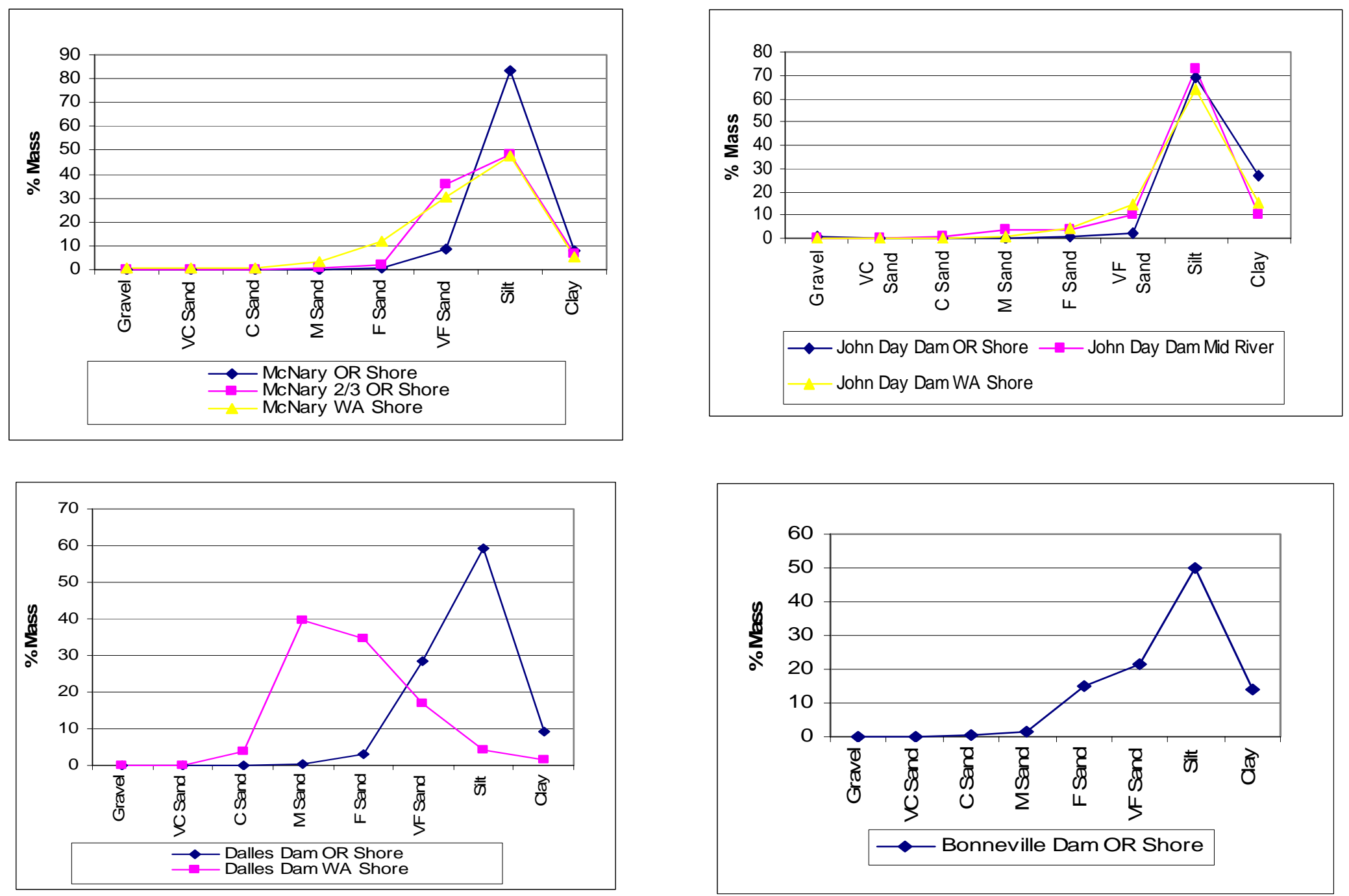

Figure 11. Sediment Grain Size Distribution for Columbia River Sediment. 

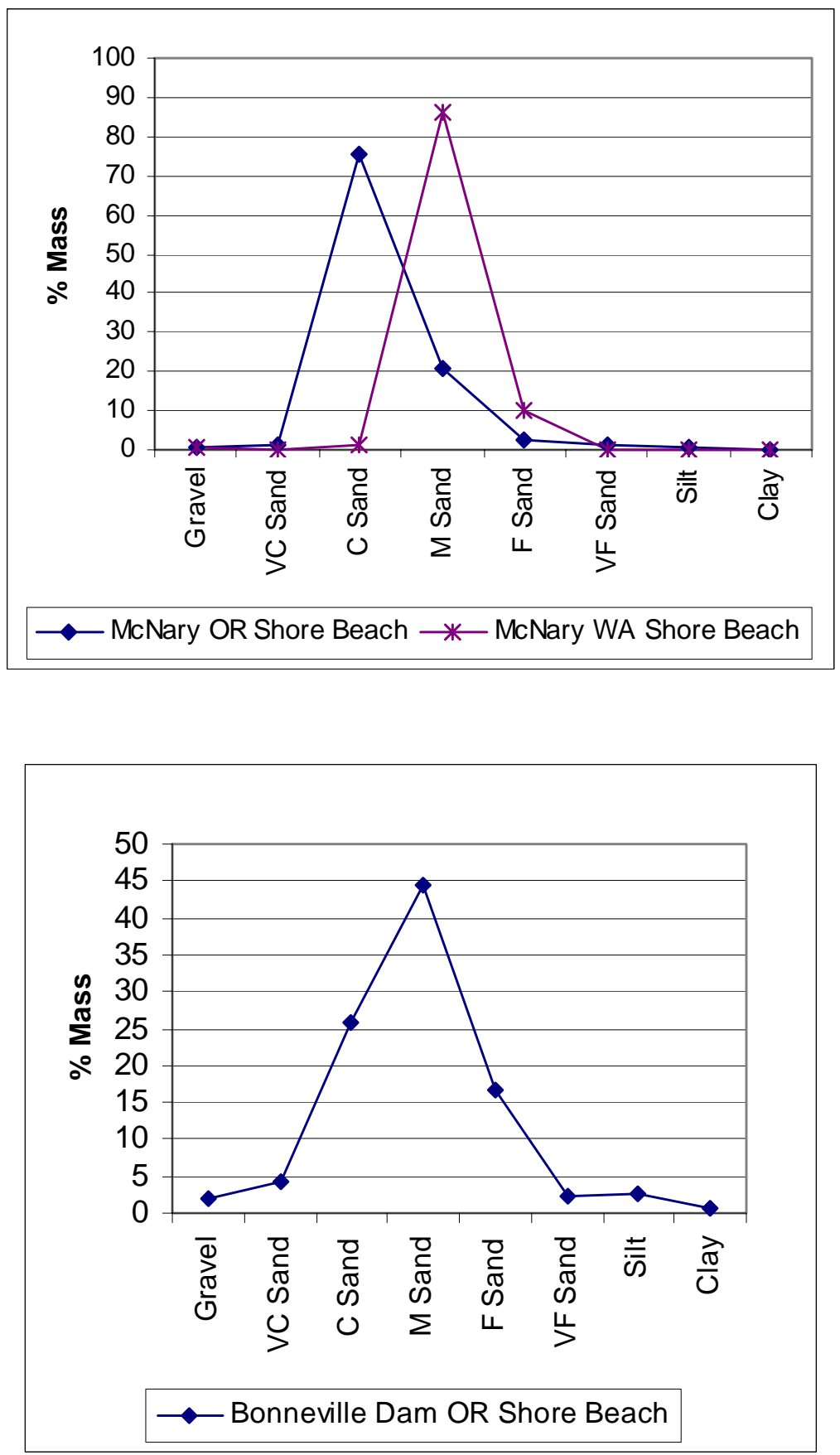

Figure 12. Sediment Grain Size Distribution for Columbia River Beach Sediment Upriver from McNary and Bonneville Dams. 


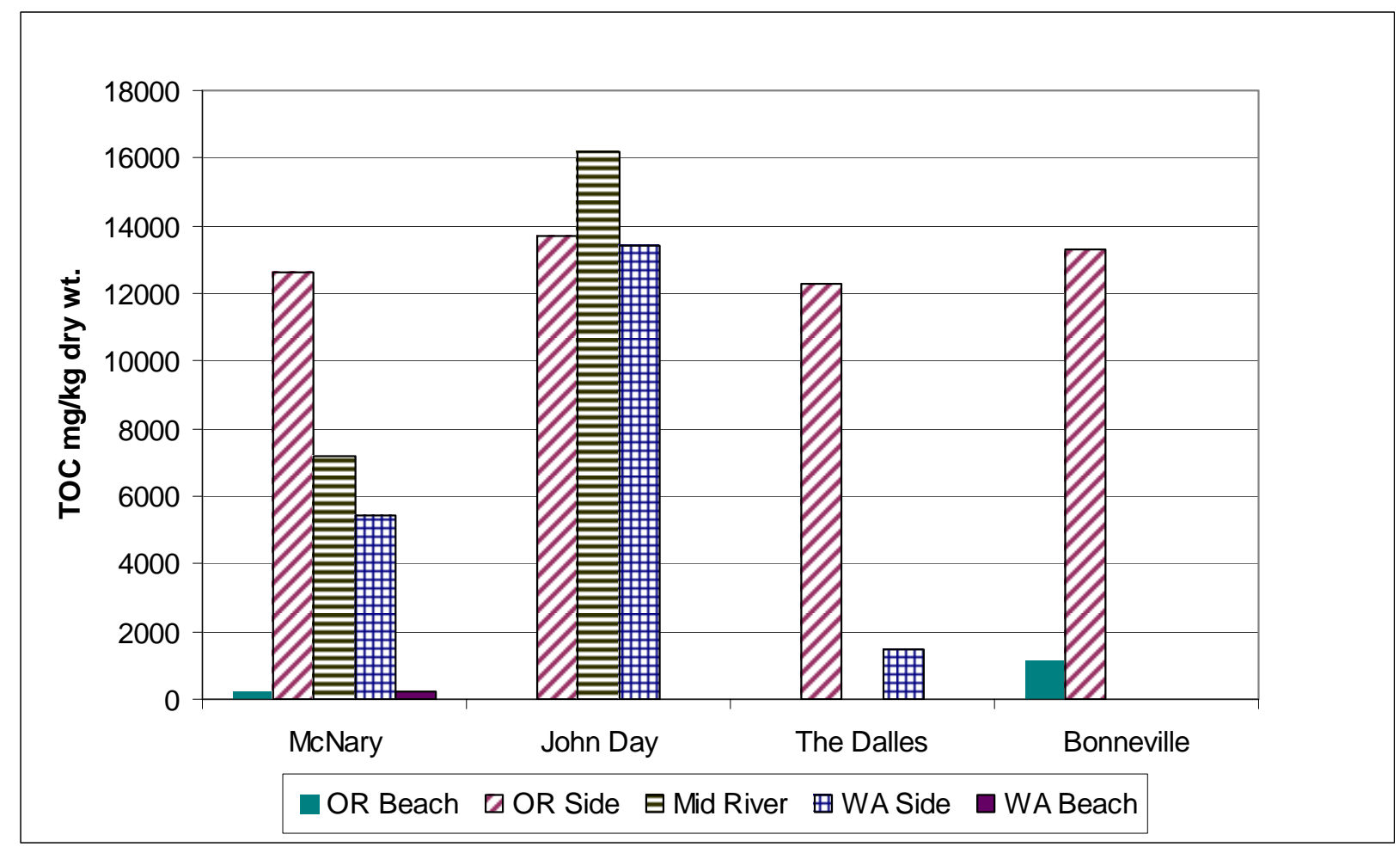

Figure 13. Total Organic Carbon Content (mg/kg dry wt.) for Columbia River and Beach Sediment.

\subsubsection{Bioassays (Microtox ${ }^{\circledR}$ and Daphnia IQ Tests)}

Microtox ${ }^{\circledR}$ and Daphnia IQ toxicity tests are rapid screening assays that have shown good prediction with more standard acute toxicity bioassays (Hayes et al. 1993; Toussaint et al. 1995; Burton et al. 2001). Evaluation of porewater toxicity can be informative because sediments integrate contaminant fluctuations over time (Nipper et al. 2003).

Microtox ${ }^{\circledR}$ has been evaluated by the Washington State Department of Ecology for use as a screening test for sediments (Bennet and Cubbage 1992). It is most appropriately used in a battery of tests where sediment is evaluated based on the results of several different bioassays. The Daphnia IQ test measures inhibition of galactosidase, reducing in vivo cleavage of a fluorometric substrate, methylumbelliferyl (MUF) galactoside (Hayes et al. 1993). The test employs the freshwater cladoceran, Daphnia magna, a common aquatic invertebrate used in toxicity testing. Those organisms that feed normally and retain functional galactosidase are able to cleave the MUF marker from the substrate. The fluorescent marker is then freed to the hemolymph of the organism and is readily observed. Janssen and Persoone (1993) found the Daphnia Magna IQ test to be substantially more sensitive than the Microtox ${ }^{\circledR}$ assay for copper (170x), cadmium (1,216x), zinc (110x), and chromium (3,417x), and similarly sensitive for mercury.

The $\mathrm{EC}_{50}$ is the sample concentration that causes $50 \%$ of the exposed bacteria to exhibit a predetermined adverse response at a specific time. High $\mathrm{EC}_{50}$ indicates low toxicity, while low values indicate high 
toxicity. For example, an $\mathrm{EC}_{50}$ of $80 \%$ is less toxic than an $\mathrm{EC}_{50}$ of $25 \%$. The $\mathrm{EC}_{50}$ data in Table 3 indicate that the Daphnia IQ test was more sensitive than the Microtox ${ }^{\circledR}$ test.

Table 3. Effective Dose $\left(\mathrm{EC}_{50}\right)$ for Microtox ${ }^{\circledR}(\mathrm{n}=1)$ and Daphnia IQ Toxicity Tests $(\mathrm{n}=3)$

\begin{tabular}{||l|c|c|c|c|c||}
\hline \multirow{2}{*}{$\begin{array}{c}\text { Dam } \\
\text { Sediment }\end{array}$} & \multicolumn{4}{|c||}{ Microtox $\mathrm{EC}_{50}(\%)$} & ${\text { Daphnia } \text { IQ EC }_{50}(\mathrm{CL})(\%)^{(\mathrm{a})}}$ \\
\cline { 2 - 6 } & $0.2 \mu \mathrm{m}$ Filtered & \multicolumn{2}{|c||}{ Non-Filtered } & Non-Filtered \\
\hline Porewater & $5 \mathrm{~min}$ & $15 \mathrm{~min}$ & $5 \mathrm{~min}$ & $15 \mathrm{~min}$ & $75 \mathrm{~min}$ \\
\hline \hline McNary & $>100^{(\mathrm{b})}$ & $>100^{(\mathrm{b})}$ & $>100^{(\mathrm{b})}$ & $>100^{(\mathrm{b})}$ & $78.3(56.0-143)$ \\
\hline John Day & $>100^{(\mathrm{b})}$ & $>100^{(\mathrm{b})}$ & $>100^{(\mathrm{b})}$ & $>100^{(\mathrm{b})}$ & $22.4(15.8-31.1)$ \\
\hline Dalles & $>100^{(\mathrm{b})}$ & $>100^{(\mathrm{b})}$ & $>100^{(\mathrm{b})}$ & $>100^{(\mathrm{b})}$ & $51.8(42.2-63.9)$ \\
\hline Bonneville & $>100^{(\mathrm{b})}$ & $>100^{(\mathrm{b})}$ & $>100^{(\mathrm{b})}$ & $>100^{(\mathrm{b})}$ & $33.2(27.1-40.7)$ \\
\hline $\begin{array}{l}\text { (a) 95\% Confidence Limit. } \\
\text { (b) Extrapolated value. }\end{array}$ \\
\hline
\end{tabular}

The Microtox ${ }^{\circledR}$ evaluations of sediment porewater demonstrated no observed toxicity with all results reported as being greater than $100 \%$.

The Daphnia IQ test exhibited some measurable toxicity, relative to controls. Toxicity of sediment porewater was greatest for sediment porewater from John Day Dam and least for sediment porewater from McNary Dam. The sediment porewater toxicity was inversely related to the amount of acid volatile sulfide measured for the sediment sampling locations (Figure 14). The sediment with high acid volatile sulfide loadings come from a reducing environment (low oxygen content) and this may have influenced the toxicity results. There were no other readily apparent trends between toxicity and contaminant levels at the sampling locations. 


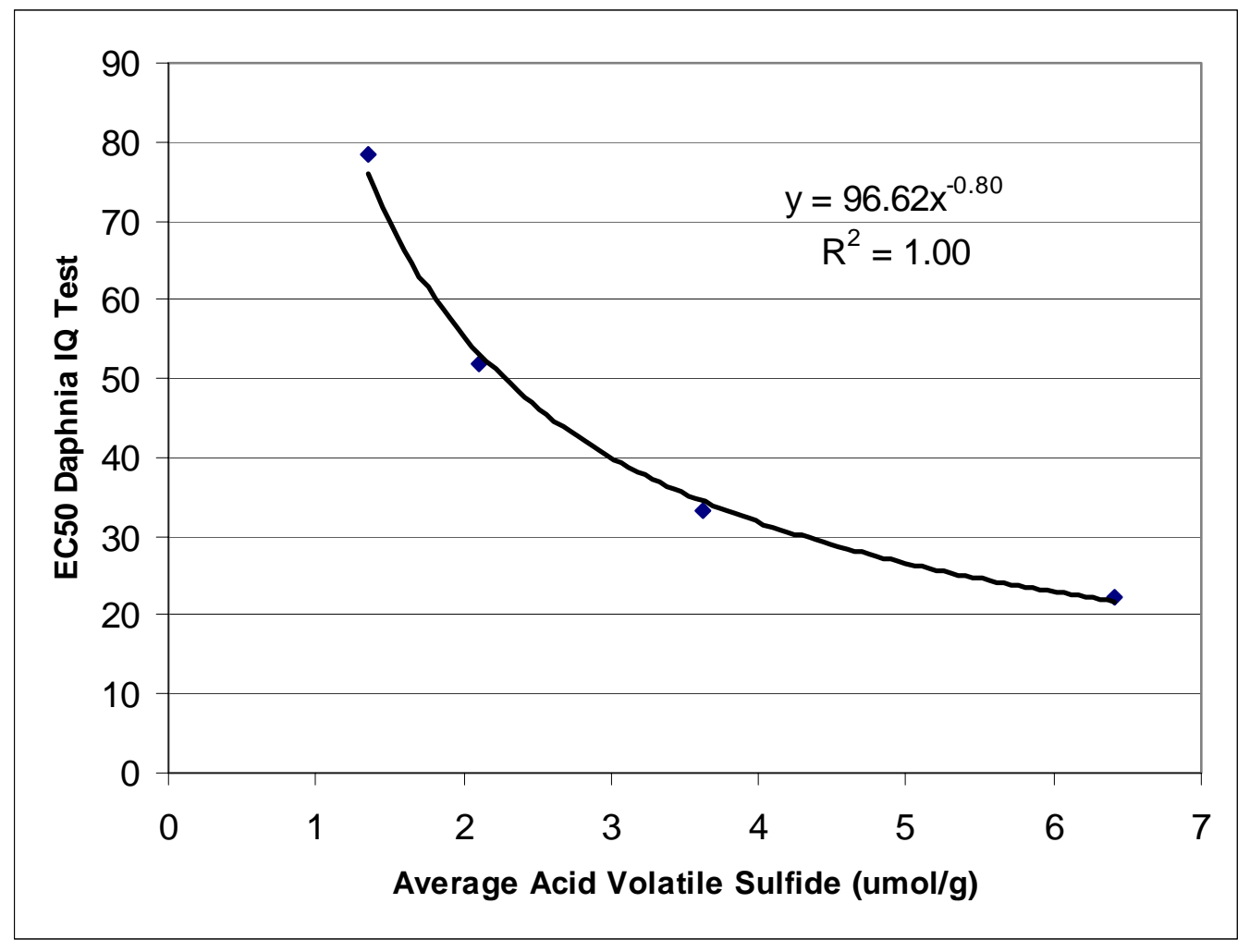

Figure 14. Relationship Between Dapnia IQ Test Results (EC50) for Sediment Porewater and Average Acid Volatile Sulfide Concentrations in Associated Sediments.

\subsection{Radionuclides in Columbia River Water}

River water samples were collected at McNary Dam reservoir at the same locations as the river sediment samples. The mid-river (McNary 2/3 OR Shore) location was analyzed for gamma-emitting radionuclides, strontium-90, isotopic uranium, and isotopic plutonium. The water samples from the Washington and Oregon sides of the river at McNary Dam were only analyzed for strontium-90. The results for the water samples analyzed for radionuclides are presented in Appendix B, Table B.8. In general, the water concentrations at McNary Dam were similar to levels reported by the Hanford Site Surface Environmental Surveillance Project for the Richland Pumphouse and Priest Rapids Dam (Poston et al. 2003). Strontium-90 was detected in all water samples with values ranging from 0.12 to $0.15 \mathrm{pCi} / \mathrm{L}$, which were well below the Washington State ambient water quality criteria of $8 \mathrm{pCi} / \mathrm{L}$. The concentration of total uranium in water at McNary Dam $(0.45 \pm 0.051 \mathrm{pCi} / \mathrm{L})$ was well below the EPA drinking water standard of 30 pg/L ( 27 pCi/L) (40 CFR 141; WAC 246-290; EPA 822-R-96-001). Gamma-emitting radionuclides, uranium-235, and isotopic plutonium were below the detection limits. 


\subsection{Conclusions}

In 2003, sediment samples were collected in the impoundments upriver from McNary, John Day, The Dalles, and Bonneville Dams and at beaches along the shores of the impoundments (where available). The upper layer sediment was readily available upriver from McNary, John Day, and The Dalles Dams. Sediment was limited (as determined by unsuccessful attempts to collect samples) upriver of the Bonneville Dam and was only successfully collected in close proximity to the dam structure. Beach sediment sampling locations were limited to above McNary Dam and at the mouth of Eagle Creek on the Oregon side of the Bonneville Dam impoundment. In general, the river sediment samples were composed primarily of very fine sand, silt, and clay; whereas the beach sediment was composed primarily of coarse and medium sand. At McNary Dam and The Dalles Dam, there was a trend for coarse grained sediment on the Washington side of the river. Total organic content of the river sediment was fairly consistent, with most locations having concentrations above $10,000 \mathrm{mg} / \mathrm{kg}$, and the locations with higher organic content generally had finer grain sediment. Samples from the Washington side of the McNary Dam and The Dalles Dam had lower total organic content.

Sediment samples submitted for radionuclide analysis had detectable levels of potassium-40, cobalt-60, strontium-90, cesium-137, europium-152, isotopic uranium, and isotopic plutonium. In general, the values were similar to previously reported concentrations at Priest Rapids Dam (Wells 1994; OHD 1994; Poston et al. 2003). Cesium-137 and europium-152 concentrations were somewhat elevated at the lower Columbia River pools compared to sediment from the Priest Rapids pool; this provides an indication of a potential Hanford source; however, additional sampling and evaluation would be required to confirm this information.

Metals were detected in most river and beach sediment samples, with the levels reported for this study similar to previously reported values (Patton and Crecelius 2001; Poston et al. 2003). Median concentrations of cadmium, arsenic, nickel, copper, lead, chromium, and zinc were highest for sediment collected at the Priest Rapids Dam pool. Compared to Priest Rapid Dam sediment, the median concentrations of mercury, silver, selenium, antimony, and thallium were generally higher for the downriver pools. Median sediment concentrations for antimony, cadmium, silver (John Day Dam only), and zinc were all above the proposed Washington State sediment quality criteria (Michelsen 2003). Samples submitted for hexavalent chromium analysis were all below the detection limit. There was no indication of a unique Hanford Site contribution for metals in Columbia River sediment.

Sediment samples analyzed for organic compounds (e.g., PAHs, PCBs, pesticides, and semi-volatile organics) were all below the analytical detections limits. The analytical detection limits were below the proposed Washington State sediment quality criteria (Michelsen 2003).

Sediment porewater toxicity was not observed with the MicroTox ${ }^{\circledR}$ test for any of the sediment sampling locations. The Daphnia IQ test exhibited some measurable toxicity for sediment porewater, relative to controls. Toxicity of sediment porewater was greatest for sediment porewater from John Day Dam and least for sediment porewater from McNary Dam. The sediment porewater toxicity was inversely related 
to the amount of AVS measured for the sediment sampling locations. There were no other readily apparent trends between toxicity and contaminant levels at the sampling locations.

The water concentrations at McNary Dam were similar to levels reported by the Hanford Site Surface Environmental Surveillance Project for the Richland Pumphouse and Priest Rapids Dam (Poston et al. 2003). Strontium-90 was detected in all water samples with values ranging from 0.12 to $0.15 \mathrm{pCi} / \mathrm{L}$, which were well below the Washington State ambient water quality criteria of $8 \mathrm{pCi} / \mathrm{L}$. The concentration of total uranium concentration in water at McNary Dam $(0.45 \pm 0.051 \mathrm{pCi} / \mathrm{L})$ was below the EPA drinking water standard of $30 \mu \mathrm{g} / \mathrm{L}$ ( $27 \mathrm{pCi} / \mathrm{L}$ ) (40 CFR 141; WAC 246-290; EPA 822-R-96001). Gamma-emitting radionuclides, uranium-235, and isotopic plutonium were below the detection limits.

In summary, low concentrations of radionuclides were observed in upper layer sediment samples from the lower Columbia River. The concentrations of most radionuclides in the lower Columbia River sediment were similar to background values measured upstream from the Hanford Site. Cesium-137 and Europium-152 values were slightly elevated at McNary Dam and may indicate some Hanford Site contribution; however, additional sampling and evaluation would be required to confirm this information. Sediment concentrations for antimony, cadmium, silver (John Day Dam only), and zinc were all above the proposed Washington State sediment quality criteria. Samples submitted for hexavalent chromium analysis were all below the detection limit. There was no indication of a unique Hanford Site contribution for metals in Columbia River sediment. Sediment samples analyzed for organic compounds (e.g., PAHs, PCBs, pesticides, and semi-volatile organics) were all below the analytical detection limits. Sediment porewater toxicity was not observed with the MicroTox ${ }^{\circledR}$ test for any of the sediment sampling locations. The Daphnia IQ test exhibited some measurable toxicity, relative to controls.

\subsection{References}

40 CFR 141. U.S. Environmental Protection Agency. "National Primary Drinking Water Regulations; Radionuclides; Proposed Rule. U.S. Code of Regulations.

Beasley MT, DC Jennings, and AD McCullough. 1986. "Sediment Accumulation Rates in the Lower Columbia River.” J. Environ. Radioactivity 3:103-123.

Bennett J and J Cubbage. 1992. Review and Evaluation of Microtox ${ }^{\circledR}$ Test for Freshwater Sediments. Publication \#92-e04, Washington State Department of Ecology, Olympia, Washington. Available URL: (http://www.ecy.wa.gov/biblio/92e04.html)

Bisping, LE. 2003. Hanford Site Environmental Surveillance Master Sampling Schedule for Calendar Year 2003. PNNL-14184, Pacific Northwest National Laboratory, Richland, Washington.

Blanton ML, WW Gardiner, and RL Dirkes. 1995. Environmental Monitoring of Columbia River Sediments: Grain-Size Distribution and Contaminant Association. PNL-10535, Pacific Northwest Laboratory, Richland, Washington. 
Bulich AA. 1979. "Use of a Luminescent Bacteria for Determining Toxicity in Aquatic Environments." In Aquatic Toxicology, ASTM STP 667, pp. 98-106, LL Marking and RA Kimerle (eds.), Amer. Soc. Test. Mat., Philadelphia, Pennsylvania.

Burton GA, R Baudo, M Beltrami, and C Rowland. 2001. “Assessing Sediment Contamination using Six Toxicity Assays.” J. Limnol. 60(2):263-267.

Cushing, CE, DG Watson, AJ Scott, and JM Gurtisen. 1981.”Decrease of Radionuclides in Columbia River Biota Following Closure of Hanford Reactors.” Health Phys., 41:59-67.

DeWitt TH, RC Swartz, DJ Hansen, D McGovern, and WJ Berry. 1996. "Bioavailability and Chronic Toxicity of Cadmium in Sediment to the Estuarine Amphipod Leptocheirus Plumulosus.” Environ. Toxicology and Chemistry 15:2095-2101.

DOE. 1998. Screening Assessment and Requirements for a Comprehensive Assessment, Columbia River Comprehensive Impact Assessment. DOE/RL-96-16, Rev. 1, U.S. Department of Energy, Richland Operations Office, Richland, Washington.

DOE. 2002. The Hanford Site Historic District, 1943 - 1990. DOE/RL-97-1047, U.S. Department of Energy, Richland Operations Office, Richland, Washington.

EPA. 2002. Columbia River Basin Fish Contaminant Survey 1996 - 1998. EPA 910-R-02-006, Region 10, U.S Environmental Protection Agency, Seattle, Washington.

http://yosemite.epa.gov/r10/oea.nsf/0703BC6B0C5525B088256BDC0076FC44/C3A9164ED2693537882 56C09005D36B7?OpenDocument

EPA 822-R-96-001. 1996. Drinking Water Regulations and Health Advisories. U.S. Environmental Protection Agency, Office of Water, Washington, D.C.

Erickson, M. D. 1997. Analytical Chemistry of PCBs, Second Edition, Lewis Publishers, Boca Raton, Florida.

Gibbons, G. J. 2000. An Investigation of the Origin of ${ }^{152}$ Eu in Columbia River Sediments. Masters Thesis, Idaho State University, Department of Physics, Pocatello, Idaho.

Hansen DJ, WJ Berry, JD Mahony, WS Boothman, DM DiToro, DL Robson, GT Ankley, D Ma, Q Yan, and CE Pesch. 1996. "Predicting the Toxicity of Metal-Contaminated Field Sediments Using Interstitial Concentrations of Metals and Acid-Volatile Sulfide Normalizations.” Environ. Toxicology and Chemistry 15:2080-2094.

Hayes KR, WS Douglass, Y Terrell, J Fischer, LA Lyons, and LJ Briggs. 1993. "Predictive Ability of the Daphnia magna IQ Toxicity Test for Ten Diverse Water Treatment Additives.” Bull. Environ. Contam. Toxicol. 51:909-913.

HEDR (Hanford Environmental Dose Reconstruction Project). 1994. Summary: Radiation Dose Estimates from Hanford Radioactive Material Releases to the Air and the Columbia River. Issued by the 
Technical Steering Panel of the Hanford Environmental Dose Reconstruction Project, Washington State Department of Ecology, Olympia, Washington.

Janssen CR and G Persoone. 1993. "Rapid Toxicity Screening Tests for Aquatic Biota. Methodology and Experiments with Daphnia magna.” Environmental Toxicology and Chemistry 12:711-717.

Michelsen, TM. 2003. “Development of Freshwater Sediment Quality Values for Use in Washington State”,Phase II Report: Development and Recommendations for SQVs for Freshwater Sediment in Washington State. Publication Number 03-09-088 Prepared for Washington Department of Ecology, Toxics Cleanup Program, Sediment Management Unit by Avocet Consulting, Kenmore, WA under contract to Science Applications International Corporation, Bothell, Washington.

Nipper M, RS Carr, WJ Adams, WJ Berry, GA Burton, KT Ho, DD MacDonald, R Scroggins, and PV Winger. 2003. "Recommendations for Research Related to Biological, Chemical, and Ecological Aspects of Sediment Porewater: The Way Forward.” In Porewater Toxicity Testing: Biological, Chemical, and Ecological Considerations, RS Carr and M Nipper (eds.), pp. 285-292, SETAC Press, Pensacola, Florida.

OHD. 1994. Environmental Radiological Surveillance Report on Oregon Surface Waters 1961-1993. Oregon Health Division, Radiation Protection Services, Portland, Oregon.

http://www.ohd.hr.state.or.us/rps/docs/6293new9.pdf

OHWB. 2002. River Without Waste: Recommendations for Protecting the Columbia River from Hanford Site Nuclear Waste. Oregon Hanford Waste Board. http://www.energy.state.or.us/nucsafe/River\%20Without\%20Waste.pdf

Patton GW, AT Cooper, and ML Blanton. 1994. Measurement and Estimated Health Risks of Volatile Organic Compounds and Polychlorinated Biphenyls in Air at the Hanford Site. PNL-10168, Pacific Northwest Laboratory, Richland, Washington.

Patton GW, AT Cooper, RG Riley, LF Lefkovitz, and TJ Gilfoil. 1997a. Investigation of Potential Polychlorinated Biphenyl (PCB) Contamination on Hanford Site Arc-Loop Roads. PNNL-11651, Pacific Northwest National Laboratory, Richland, Washington.

Patton GW, AT Cooper, ML Blanton, LF Lefkovitz, and TJ Gilfoil. 1997b. Measurement and Estimated Health Risks of Semivolatile Organic Compounds (PCBs, PAHs, Pesticides, and Phthalates) in Ambient Air at the Hanford Site. PNNL-11650, Pacific Northwest National Laboratory, Richland, Washington.

Patton GW and EA Crecelius. 2001. Simultaneously Extracted Metals/Acid Volatile Sulfide and Total Metals in Surface Sediment from the Hanford Reach of the Columbia River and the Lower Snake River. PNNL-13417, Pacific Northwest National Laboratory, Richland, Washington.

Poston TM, RW Hanf, and RL Dirkes (eds.). 2000. Hanford Site Environmental Report for Calendar Year 1999. PNNL-13230, Pacific Northwest National Laboratory, Richland, Washington. 
Poston TM, RW Hanf, RL Dirkes, and LF Morasch (eds.). 2003. Hanford Site Environmental Report for Calendar Year 2002. PNNL-14295, Pacific Northwest National Laboratory, Richland, Washington.

PNNL. 2003. Surface Environmental Surveillance Procedures Manual. PNL-MA-580, Pacific Northwest Laboratory, Richland, Washington.

Robertson, D. E. and J. J. Fix. 1977. Association of Hanford Origin Radionuclides with Columbia River Sediment. BNWL-2305, Battelle Pacific Northwest Laboratory, Richland, Washington.

SAIC and Avocet. 2002. "Development of Freshwater Sediment Quality Values for Use in Washington State. Phase I Task 6”. Publication Number 02-09-050, prepared for Washington Department of Ecology Sediment Management Unit, prepared by Science Applications International Corporation (SAIC, Bothell Washington) and Avocet Consulting (Kenmore, Washington).

Sula MJ. 1980. Radiological Survey of Exposed Shoreline and Islands of the Columbia River between Vernita and the Snake River Confluence. PNL-3127, Pacific Northwest Laboratory, Richland, Washington.

Toussaint MW, TR Shedd, WH Van der Schalie, and GR Leather. 1995. "A Comparison of Standard Acute Toxicity Tests with Rapid Screening Toxicity Tests.” Environ. Toxicol. Chem. 14:907-915.

Washington Agricultural Statistics Service. 1994. Washington Agri-Facts, March 10, 2004, Washington Agricultural Statistics Service, U.S. Department of Agriculture, Washington, DC.

http://www.nass.usda.gov/wa/agri1mar.pdf

Washington State Department of Ecology. 1996. Pesticides in Ground Water Report No. 9, April 1996, Publication No. 96-303, Olympia, Washington.

WAC 173-201A. "Water Quality Standards for Surface Waters of the State of Washington.” Washington Administrative Code, Olympia, Washington.

WAC 246-290. “Group A Public Water Systems.” Washington Administrative Code, Olympia, Washington.

Wells D. 1994. Special Report: Radioactivity in Columbia River Sediments and Their Health Effects. Washington State Department of Health, Olympia, Washington.

Woodruff RK, RW Hanf, and RE Lundgren (eds.). 1992. Hanford Site Environmental Report for Calendar Year 1991. PNL-8148, Pacific Northwest Laboratory, Richland, Washington. 
Appendix A

Quality Assurance 


\section{Appendix A}

\section{Quality Assurance}

\section{A.1 Washington State Department of Ecology Quality Assurance/Quality Control}

The quality of the data produced and used by WDOE is assured in many ways. WDOE has specific responsibilities and requirements pertaining to data quality for contract analytical laboratories. Analysis and receipt of samples must be conducted in licensed facilities. The laboratory must participate in the organic and inorganic U.S. Environmental Protection Agency Intercomparison Studies Programs. The laboratory must be Washington State accredited for water and wastewater analysis. A chemical hygiene plan which implements the safety requirements of the Occupational Safety Health Administration must be readily available in the laboratory facility. Analytical and standard operating procedures shall meet the requirements of all applicable regulations and reflect the actual operating conditions during analysis of the WDOE samples. A quality assurance plan must be implemented and updated as needed. Personnel training includes continued training to ensure job proficiency. WDOE performs audits as necessary on facilities, equipment, files, documents, laboratory information systems, and records. All standards must be made from National Institute of Science and Technology traceable materials. Data packages are defensible documentation with deliverables that include the following items as applicable for the analysis reported:

- sample results

- blank results

- MS/MSD or MS and duplicate results, recoveries, and relative percent differences

- surrogate results and recoveries

- initial and continuing calibration results and recoveries

- control standards results and recoveries

- detection limit determinations

- all raw data 


\section{A.2 Pacific Northwest National Laboratory Quality Assurance/Quality Control}

Procedures for field sampling were consistent with the PNNL Ecological Monitoring Project and the Hanford Site Surface Environmental Surveillance Project. Procedures for sample collections (including sample handling and chain-of-custody) were consistent with the Surface Environmental Surveillance Procedures Manual (PNNL 2003) and the Quality Assurance Project Plan for the Hanford Site Surface Environmental Surveillance Project (SESP) and the Drinking Water Monitoring Project (DWMP) (PNNL 2002).

\section{A.3 Washington State Department of Health Quality Assurance/Quality Control}

The Washington State Department of Health samples were analyzed for radionuclides at the DOH Radiation Laboratory in Shoreline, Washington. Analytical techniques are based on laboratory standard operating procedures (DOH 2002). The quality assurance program is documented in the laboratory's quality assurance manual (DOH 2002b).

\section{A.4 Oregon Department of Energy Quality Assurance/Quality Control}

Samples collected by the ODOE were analyzed by Oregon State University according to their quality assurance/quality control procedures. The maintenance of quality assurance and control with the Oregon State University Radiological Laboratory, located in Corvallis, Oregon, is achieved through the application of common protocols which are consistent with the radiological analysis industry. Key quality program tasks conducted for this analysis group were the establishment of initial and final counting efficiencies, along with counter calibration; use of traceable radioactivity standards; and determination of a project-specific counting background.

For example, each sample was counted for $~ 11$ hours in order to achieve reasonable counting statistics. As mentioned, a background count was obtained for a blank sample container under identical conditions. This background count was removed from each sample's measured gamma spectrum and the resulting net spectrum was analyzed for isotopic signatures. The detector was calibrated with a multi-nuclide standard source. The calibration standard is encapsulated in a $500 \mathrm{~mL}$ Marinelli beaker and has the same geometry as the unknown and blank samples. It contains the following radionuclides: Cd-109, Co-57, Te-123m, Cr51, Sn-113, Sr-85, Cs-137, Y-88, and Co-60. The activity of the standards was $187.3 \mathrm{kBq}$ on April 15, 2002.

The counting equipment at the Oregon State University Radiation Center is calibrated quarterly using the above described source. The quality assurance and quality control database is updated during these times. 


\section{A.5 References}

PNNL. 2002. Quality Assurance Project Plan for the Hanford Site Surface Environmental Surveillance Project (SESP) and the Drinking Water Monitoring Project (DWMP). ETD-011, Rev. 4, Pacific Northwest National Laboratory, Richland, Washington.

PNNL. 2003. Surface Environmental Surveillance Procedures Manual. PNL-MA-580, Pacific Northwest Laboratory, Richland, Washington.

DOH 2002. Radiation Laboratory Procedures Manual. Volumes 1 and 2. Washington State Department of Health, Division of Epidemiology, Health Statistics and Public Health. Laboratory Sciences, Radiation Chemistry Group.

DOH 2002b. Radiation Laboratory QA Manual. Washington State Department of Health, Division of Epidemiology, Health Statistics and Public Health. Laboratory Sciences, Radiation Chemistry Group. 


\section{Appendix B}

\section{Results for Columbia River Sediment, Beach Sediment, and Water Samples}


Table B.1. Concentrations of Radionuclides in Columbia River Sediment

\begin{tabular}{|c|c|c|c|c|c|c|}
\hline Site & Analyte & Result & Error $^{(a)}$ & $\mathrm{LLD}^{(\mathrm{b})}$ & $\mathrm{MDA}^{(\mathrm{c})}$ & Agency \\
\hline Bonneville Dam OR Shore & $\mathrm{Be}-7$ & 0.0547 & 0.29 & & 0.52 & PNNL \\
\hline Dalles Dam OR Shore & Be-7 & -0.044 & 0.29 & & 0.495 & PNNL \\
\hline John Day Dam Mid-River & Be-7 & 0.273 & 0.27 & & 0.497 & PNNL \\
\hline McNary 2/3 OR Shore & Be-7 & -0.016 & 0.23 & & 0.385 & PNNL \\
\hline McNary 2/3 OR Shore & Be-7 & 0.0551 & 0.28 & & 0.493 & PNNL \\
\hline Priest Rapids Dam Grant Co. Side & $\mathrm{Be}-7$ & 0.0658 & 0.12 & & 0.208 & PNNL \\
\hline Priest Rapids Dam Yakima Co. Side & Be-7 & 0.0976 & 0.11 & & 0.199 & PNNL \\
\hline Bonneville Beach (OR) & Co-60 & 0.012 & 0.009 & & & ODOE \\
\hline Bonneville Beach (OR) & Сo-60 & 0.003 & 0.006 & 0.01 & 0.01 & $\mathrm{DOH}$ \\
\hline Bonneville Dam OR Shore & Сo-60 & 0.0224 & 0.032 & & 0.0619 & PNNL \\
\hline Bonneville Dam OR Shore & Co-60 & 0 & 0.004 & 0.01 & 0.006 & $\mathrm{DOH}$ \\
\hline Bonneville Dam OR Shore & Сo-60 & ND & & & & ODOE \\
\hline Dalles Dam WA Shore & Сo-60 & 0.015 & 0.012 & & & ODOE \\
\hline Dalles Dam OR Shore & Сo-60 & 0.0046 & 0.028 & & 0.0527 & PNNL \\
\hline Dalles Dam OR Shore & Co-60 & 0.01 & 0.006 & 0.01 & 0.01 & $\mathrm{DOH}$ \\
\hline Dalles Dam WA Shore & Сo-60 & 0.014 & 0.004 & 0.01 & 0.008 & $\mathrm{DOH}$ \\
\hline Dalles Dam OR Shore & Сo-60 & 0.025 & 0.019 & & & ODOE \\
\hline John Day Dam WA Shore & Co-60 & 0.029 & 0.018 & & & ODOE \\
\hline John Day Dam Mid-River & Сo-60 & 0.0373 & 0.035 & & 0.0664 & PNNL \\
\hline John Day Dam Mid-River & Co-60 & $\mathrm{ND}$ & & & & ODOE \\
\hline John Day Dam Mid-River & Сo-60 & 0.012 & 0.007 & 0.01 & 0.0124 & $\mathrm{DOH}$ \\
\hline John Day Dam OR Shore & Co-60 & 0.049 & 0.012 & 0.01 & & $\mathrm{DOH}$ \\
\hline John Day Dam WA Shore & Co-60 & 0.022 & 0.011 & 0.01 & & $\mathrm{DOH}$ \\
\hline John Day Dam OR Shore & Сo-60 & 0.076 & 0.028 & & & ODOE \\
\hline McNary 2/3 OR Shore & Сo-60 & 0.08 & 0.04 & & & ODOE \\
\hline McNary 2/3 OR Shore & Co-60 & 0.067 & 0.022 & & & ODOE \\
\hline McNary 2/3 OR Shore & Сo-60 & 0.037 & 0.007 & 0.01 & & $\mathrm{DOH}$ \\
\hline McNary 2/3 OR Shore & Сo-60 & 0.045 & 0.013 & 0.01 & & $\mathrm{DOH}$ \\
\hline McNary 2/3 OR Shore & Co-60 & 0.0597 & 0.034 & & 0.0684 & PNNL \\
\hline McNary 2/3 OR Shore & Co-60 & 0.0619 & 0.028 & & 0.0559 & PNNL \\
\hline McNary OR Beach & Co-60 & 0.015 & 0.013 & & & ODOE \\
\hline McNary WA Beach & Co-60 & ND & & & & ODOE \\
\hline McNary OR Beach & Co-60 & 0.005 & 0.004 & 0.01 & 0.0063 & $\mathrm{DOH}$ \\
\hline McNary OR Shore & Co-60 & 0.02 & 0.01 & 0.01 & 0.0188 & $\mathrm{DOH}$ \\
\hline McNary OR Shore & Co-60 & ND & & & & ODOE \\
\hline McNary WA Beach & Co-60 & 0 & 0.006 & 0.01 & 0.0105 & $\mathrm{DOH}$ \\
\hline
\end{tabular}


Table B.1. (contd)

\begin{tabular}{|c|c|c|c|c|c|c|}
\hline Site & Analyte & Result & Error $^{(a)}$ & $\operatorname{LLD}^{(b)}$ & $\mathrm{MDA}^{(\mathrm{c})}$ & Agency \\
\hline McNary WA Shore & Сo-60 & 0.042 & 0.017 & & & ODOE \\
\hline McNary WA Shore & Co-60 & 0.008 & 0.006 & 0.01 & 0.0097 & $\mathrm{DOH}$ \\
\hline Priest Rapids Dam Grant Co. Side & Сo-60 & -0.0003 & 0.012 & & 0.0209 & PNNL \\
\hline Priest Rapids Dam Yakima Co. Side & Сo-60 & 0.004 & 0.011 & & 0.0203 & PNNL \\
\hline Bonneville Dam OR Shore & Cs-134 & 0.0508 & 0.06 & & 0.0777 & PNNL \\
\hline Dalles Dam OR Shore & Cs-134 & 0.0325 & 0.036 & & 0.0663 & PNNL \\
\hline John Day Dam Mid-River & Cs-134 & 0.0765 & 0.036 & & 0.0682 & PNNL \\
\hline McNary 2/3 OR Shore & Cs-134 & 0.0456 & 0.035 & & 0.0648 & PNNL \\
\hline McNary 2/3 OR Shore & Cs-134 & 0.0645 & 0.029 & & 0.0545 & PNNL \\
\hline Priest Rapids Dam Grant Co. Side & Cs-134 & 0.0456 & 0.018 & & 0.0264 & PNNL \\
\hline Priest Rapids Dam Yakima Co. Side & Cs-134 & 0.0347 & 0.016 & & 0.0237 & PNNL \\
\hline Bonneville Beach (OR) & Cs-137 & 0.101 & 0.017 & & & ODOE \\
\hline Bonneville Beach (OR) & Cs-137 & 0.14 & 0.02 & 0.01 & & $\mathrm{DOH}$ \\
\hline Bonneville Dam OR Shore & Cs-137 & 0.146 & 0.05 & & 0.0569 & PNNL \\
\hline Bonneville Dam OR Shore & Cs-137 & 0.094 & 0.009 & 0.01 & & $\mathrm{DOH}$ \\
\hline Bonneville Dam OR Shore & Cs-137 & 0.173 & 0.031 & & & ODOE \\
\hline Dalles Dam WA Shore & Cs-137 & 0.107 & 0.019 & & & ODOE \\
\hline Dalles Dam OR Shore & Cs-137 & 0.155 & 0.058 & & 0.0565 & PNNL \\
\hline Dalles Dam OR Shore & Cs-137 & 0.15 & 0.01 & 0.01 & & $\mathrm{DOH}$ \\
\hline Dalles Dam WA Shore & Cs-137 & 0.098 & 0.014 & 0.01 & & $\mathrm{DOH}$ \\
\hline Dalles Dam OR Shore & Cs-137 & 0.192 & 0.031 & & & ODOE \\
\hline John Day Dam WA Shore & Cs-137 & 0.327 & 0.04 & & & ODOE \\
\hline John Day Dam Mid-River & Cs-137 & 0.333 & 0.07 & & 0.0524 & PNNL \\
\hline John Day Dam Mid-River & Cs-137 & 0.315 & 0.04 & & & ODOE \\
\hline John Day Dam Mid-River & Cs-137 & 0.25 & 0.02 & 0.01 & & $\mathrm{DOH}$ \\
\hline John Day Dam OR Shore & Cs-137 & 0.43 & 0.03 & 0.01 & & $\mathrm{DOH}$ \\
\hline John Day Dam WA Shore & Cs-137 & 0.22 & 0.02 & 0.01 & & $\mathrm{DOH}$ \\
\hline John Day OR Shore & Cs-137 & 0.627 & 0.052 & & & ODOE \\
\hline McNary 2/3 OR Shore & Cs-137 & 0.513 & 0.046 & & & ODOE \\
\hline McNary 2/3 OR Shore & Cs-137 & 0.47 & 0.039 & & & ODOE \\
\hline McNary 2/3 OR Shore & Cs-137 & 0.4 & 0.03 & 0.01 & & $\mathrm{DOH}$ \\
\hline McNary 2/3 OR Shore & Cs-137 & 0.45 & 0.02 & 0.01 & & $\mathrm{DOH}$ \\
\hline McNary 2/3 OR Shore & Cs-137 & 0.378 & 0.081 & & 0.0388 & PNNL \\
\hline McNary 2/3 OR Shore & Cs-137 & 0.425 & 0.083 & & 0.0591 & PNNL \\
\hline McNary OR Beach & Cs-137 & 0.042 & 0.012 & & & ODOE \\
\hline McNary WA Beach & Cs-137 & 0.01 & 0.009 & & & ODOE \\
\hline
\end{tabular}


Table B.1. (contd)

\begin{tabular}{|c|c|c|c|c|c|c|}
\hline Site & Analyte & Result & Error $^{(a)}$ & $\operatorname{LLD}^{(b)}$ & $\mathrm{MDA}^{(\mathrm{c})}$ & Agency \\
\hline McNary OR Beach & Cs-137 & 0.042 & 0.007 & 0.01 & & $\mathrm{DOH}$ \\
\hline McNary OR Shore & Cs-137 & 0.23 & 0.02 & 0.01 & & $\mathrm{DOH}$ \\
\hline McNary OR Shore & Cs-137 & 0.313 & 0.041 & & & ODOE \\
\hline McNary WA Beach & Cs-137 & -0.001 & 0.006 & 0.01 & & $\mathrm{DOH}$ \\
\hline McNary WA Shore & Cs-137 & 0.424 & 0.036 & & & ODOE \\
\hline McNary WA Shore & Cs-137 & 0.41 & 0.02 & 0.01 & & $\mathrm{DOH}$ \\
\hline Priest Rapids Dam Grant Co. Side & Cs-137 & 0.324 & 0.048 & & 0.023 & PNNL \\
\hline Priest Rapids Dam Yakima Co. Side & Cs-137 & 0.285 & 0.041 & & 0.0218 & PNNL \\
\hline Bonneville Dam OR Shore & Eu-152 & -0.0564 & 0.083 & & 0.138 & PNNL \\
\hline Dalles Dam OR Shore & Eu-152 & 0.0667 & 0.088 & & 0.15 & PNNL \\
\hline John Day Dam Mid-River & Eu-152 & 0.0162 & 0.077 & & 0.133 & PNNL \\
\hline John Day Dam OR Shore & Eu-152 & 0.24 & 0.04 & 0.05 & & $\mathrm{DOH}$ \\
\hline John Day Dam WA Shore & Eu-152 & 0.071 & 0.023 & 0.05 & & $\mathrm{DOH}$ \\
\hline McNary 2/3 OR Shore & Eu-152 & 0.22 & 0.02 & 0.05 & & $\mathrm{DOH}$ \\
\hline McNary 2/3 OR Shore & Eu-152 & 0.26 & 0.03 & 0.05 & & $\mathrm{DOH}$ \\
\hline McNary 2/3 OR Shore & Eu-152 & 0.217 & 0.12 & & 0.166 & PNNL \\
\hline McNary 2/3 OR Shore & Eu-152 & 0.286 & 0.11 & & 0.136 & PNNL \\
\hline McNary OR Shore & Eu-152 & 0.054 & 0.023 & 0.05 & & $\mathrm{DOH}$ \\
\hline McNary WA Shore & Eu-152 & 0.18 & 0.02 & 0.05 & & $\mathrm{DOH}$ \\
\hline Priest Rapids Dam Grant Co. Side & Eu-152 & 0.0256 & 0.032 & & 0.0527 & PNNL \\
\hline Priest Rapids Dam Yakima Co. Side & Eu-152 & 0.00947 & 0.027 & & 0.0459 & PNNL \\
\hline Bonneville Dam OR Shore & Eu-154 & 0.0713 & 0.1 & & 0.197 & PNNL \\
\hline Dalles Dam OR Shore & Eu-154 & 0.00353 & 0.093 & & 0.168 & PNNL \\
\hline John Day Dam Mid-River & Eu-154 & 0.0379 & 0.1 & & 0.187 & PNNL \\
\hline McNary 2/3 OR Shore & Eu-154 & 0.0026 & 0.091 & & 0.162 & PNNL \\
\hline McNary 2/3 OR Shore & Eu-154 & 0.02 & 0.072 & & 0.13 & PNNL \\
\hline Priest Rapids Dam Grant Co. Side & Eu-154 & 0.011 & 0.036 & & 0.0641 & PNNL \\
\hline Priest Rapids Dam Yakima Co. Side & Eu-154 & 0.00043 & 0.035 & & 0.061 & PNNL \\
\hline Bonneville Dam OR Shore & Eu-155 & 0.0214 & 0.086 & & 0.151 & PNNL \\
\hline Dalles Dam OR Shore & Eu-155 & 0.0474 & 0.077 & & 0.136 & PNNL \\
\hline John Day Dam Mid-River & Eu-155 & 0.0761 & 0.07 & & 0.121 & PNNL \\
\hline McNary 2/3 OR Shore & Eu-155 & 0.0854 & 0.062 & & 0.109 & PNNL \\
\hline McNary 2/3 OR Shore & Eu-155 & 0.113 & 0.074 & & 0.127 & PNNL \\
\hline Priest Rapids Dam Grant Co. Side & Eu-155 & 0.0471 & 0.034 & & 0.0562 & PNNL \\
\hline Priest Rapids Dam Yakima Co. Side & Eu-155 & 0.0455 & 0.033 & & 0.0559 & PNNL \\
\hline Bonneville Beach (OR) & $\mathrm{K}-40$ & 8 & 0.476 & & & ODOE \\
\hline
\end{tabular}


Table B.1. (contd)

\begin{tabular}{|c|c|c|c|c|c|c|}
\hline Site & Analyte & Result & Error $^{(a)}$ & $\operatorname{LLD}^{(\mathrm{b})}$ & $\mathrm{MDA}^{(\mathrm{c})}$ & Agency \\
\hline Bonneville Beach (OR) & $\mathrm{K}-40$ & 13.4 & 0.5 & 0.22 & & $\mathrm{DOH}$ \\
\hline Bonneville Dam OR Shore & $\mathrm{K}-40$ & 13.1 & 2.1 & & 0.491 & PNNL \\
\hline Bonneville Dam OR Shore & $\mathrm{K}-40$ & 8.2 & 1.8 & 0.22 & & $\mathrm{DOH}$ \\
\hline Bonneville Dam OR Shore & $\mathrm{K}-40$ & 16.9 & 1.009 & & & ODOE \\
\hline Dalles Dam WA Shore & $\mathrm{K}-40$ & 16 & 0.684 & & & ODOE \\
\hline Dalles Dam OR Shore & $\mathrm{K}-40$ & 12 & 1.8 & & 0.469 & PNNL \\
\hline Dalles Dam OR Shore & $\mathrm{K}-40$ & 13.3 & 0.3 & 0.22 & & $\mathrm{DOH}$ \\
\hline Dalles Dam WA Shore & $\mathrm{K}-40$ & 15.5 & 0.6 & 0.22 & & $\mathrm{DOH}$ \\
\hline Dalles Dam OR Shore & $\mathrm{K}-40$ & 14.8 & 0.92 & & & ODOE \\
\hline John Day Dam WA Shore & $\mathrm{K}-40$ & 16.8 & 0.977 & & & ODOE \\
\hline John Day Dam Mid-River & $\mathrm{K}-40$ & 14.2 & 2.1 & & 0.417 & PNNL \\
\hline John Day Dam Mid-River & $\mathrm{K}-40$ & 16.5 & 0.994 & & & ODOE \\
\hline John Day Dam Mid-River & $\mathrm{K}-40$ & 14.7 & 0.3 & 0.22 & & $\mathrm{DOH}$ \\
\hline John Day Dam OR Shore & $\mathrm{K}-40$ & 14.1 & 0.6 & 0.22 & & $\mathrm{DOH}$ \\
\hline John Day Dam WA Shore & $\mathrm{K}-40$ & 13.4 & 0.6 & 0.22 & & $\mathrm{DOH}$ \\
\hline John Day Dam OR Shore & $\mathrm{K}-40$ & 18.7 & 1.029 & & & ODOE \\
\hline McNary 2/3 OR Shore & $\mathrm{K}-40$ & 18 & 16.5 & & & ODOE \\
\hline McNary 2/3 OR Shore & $\mathrm{K}-40$ & 16.5 & 0.816 & & & ODOE \\
\hline McNary 2/3 OR Shore & $\mathrm{K}-40$ & 15.1 & 0.6 & 0.22 & & $\mathrm{DOH}$ \\
\hline McNary 2/3 OR Shore & $\mathrm{K}-40$ & 16.3 & 0.3 & 0.22 & & $\mathrm{DOH}$ \\
\hline McNary 2/3 OR Shore & $\mathrm{K}-40$ & 14 & 2 & & 0.46 & PNNL \\
\hline McNary 2/3 OR Shore & $\mathrm{K}-40$ & 14.8 & 2 & & 0.293 & PNNL \\
\hline McNary OR Beach & $\mathrm{K}-40$ & 12.9 & 0.545 & & & ODOE \\
\hline McNary WA Beach & $\mathrm{K}-40$ & 12.9 & 0.559 & & & ODOE \\
\hline McNary OR Beach & $\mathrm{K}-40$ & 13.6 & 0.2 & 0.22 & & $\mathrm{DOH}$ \\
\hline McNary OR Shore & $\mathrm{K}-40$ & 13.7 & 0.6 & 0.22 & & $\mathrm{DOH}$ \\
\hline McNary OR Shore & $\mathrm{K}-40$ & 18.3 & 1.037 & & & ODOE \\
\hline McNary WA Beach & $\mathrm{K}-40$ & 12.6 & 0.5 & 0.22 & & $\mathrm{DOH}$ \\
\hline McNary WA Shore & $\mathrm{K}-40$ & 16.2 & 0.769 & & & ODOE \\
\hline McNary WA Shore & $\mathrm{K}-40$ & 16.2 & 0.3 & 0.22 & & $\mathrm{DOH}$ \\
\hline Priest Rapids Dam Grant Co. Side & $\mathrm{K}-40$ & 12.3 & 1.6 & & 0.183 & PNNL \\
\hline Priest Rapids Dam Yakima Co. Side & $\mathrm{K}-40$ & 12.2 & 1.6 & & 0.134 & PNNL \\
\hline Bonneville Beach (OR) & $\mathrm{Pu}-238$ & 0.003 & 0.003 & 0.03 & 0.004 & $\mathrm{DOH}$ \\
\hline Bonneville Dam OR Shore & Pu-238 & 0.00021 & 0.00044 & & 0.0008 & PNNL \\
\hline Bonneville Dam OR Shore & $\mathrm{Pu}-238$ & 0.003 & 0.003 & 0.03 & 0.004 & $\mathrm{DOH}$ \\
\hline Dalles Dam OR Shore & Pu-238 & 0.00035 & 0.00019 & & 0.0002 & PNNL \\
\hline
\end{tabular}


Table B.1. (contd)

\begin{tabular}{|c|c|c|c|c|c|c|}
\hline Site & Analyte & Result & Error $^{(a)}$ & $\operatorname{LLD}^{(\mathrm{b})}$ & $\mathrm{MDA}^{(\mathrm{c})}$ & Agency \\
\hline Dalles Dam OR Shore & Pu-238 & 0 & 0.003 & 0.03 & 0.006 & $\mathrm{DOH}$ \\
\hline Dalles Dam WA Shore & $\mathrm{Pu}-238$ & 0.02 & 0.005 & 0.03 & 0.003 & $\mathrm{DOH}$ \\
\hline John Day Dam Mid-River & Pu-238 & 0.00027 & 0.00025 & & 0.0002 & PNNL \\
\hline John Day Dam Mid-River & Pu-238 & 0 & 0.003 & 0.03 & 0.005 & $\mathrm{DOH}$ \\
\hline John Day Dam OR Shore & Pu-238 & 0 & 0.001 & 0.03 & 0.003 & $\mathrm{DOH}$ \\
\hline John Day Dam WA Shore & Pu-238 & 0 & 0.002 & 0.03 & 0.0043 & $\mathrm{DOH}$ \\
\hline McNary 2/3 OR Shore & Pu-238 & 0 & 0.002 & 0.03 & 0.005 & $\mathrm{DOH}$ \\
\hline McNary 2/3 OR Shore & Pu-238 & 0 & 0.002 & 0.03 & 0.005 & $\mathrm{DOH}$ \\
\hline McNary 2/3 OR Shore & Pu-238 & 0.0002 & 0.00018 & & 0.0002 & PNNL \\
\hline McNary 2/3 OR Shore & Pu-238 & 0.00053 & 0.00033 & & 0.0003 & PNNL \\
\hline McNary OR Beach & Pu-238 & 0 & 0.002 & 0.03 & 0.005 & $\mathrm{DOH}$ \\
\hline McNary OR Shore & Pu-238 & 0.004 & 0.003 & 0.03 & 0.004 & $\mathrm{DOH}$ \\
\hline McNary WA Beach & Pu-238 & 0 & 0.003 & 0.03 & 0.006 & $\mathrm{DOH}$ \\
\hline McNary WA Shore & Pu-238 & 0 & 0.003 & 0.03 & 0.006 & $\mathrm{DOH}$ \\
\hline Priest Rapids Dam Grant Co. Side & Pu-238 & 0.00064 & 0.00038 & & 0.0001 & PNNL \\
\hline Priest Rapids Dam Yakima Co. Side & Pu-238 & 0.00022 & 0.00026 & & 0.0002 & PNNL \\
\hline Bonneville Beach (OR) & $\mathrm{Pu}-239 / 240$ & 0.001 & 0.003 & 0.006 & 0.005 & $\mathrm{DOH}$ \\
\hline Bonneville Dam OR Shore & $\mathrm{Pu}-239 / 240$ & 0.00451 & 0.0016 & & 0.0003 & PNNL \\
\hline Bonneville Dam OR Shore & $\mathrm{Pu}-239 / 240$ & 0.014 & 0.004 & 0.006 & 0.002 & $\mathrm{DOH}$ \\
\hline Dalles Dam OR Shore & $\mathrm{Pu}-239 / 240$ & 0.00598 & 0.0011 & & $6 \mathrm{E}-05$ & PNNL \\
\hline Dalles Dam OR Shore & $\mathrm{Pu}-239 / 240$ & 0.007 & 0.003 & 0.006 & 0.003 & $\mathrm{DOH}$ \\
\hline Dalles Dam WA Shore & $\mathrm{Pu}-239 / 240$ & 0.049 & 0.008 & 0.006 & 0.002 & $\mathrm{DOH}$ \\
\hline John Day Dam Mid-River & $\mathrm{Pu}-239 / 240$ & 0.00963 & 0.0021 & & 0.0002 & PNNL \\
\hline John Day Dam Mid-River & Pu-239/240 & 0.008 & 0.003 & 0.006 & & $\mathrm{DOH}$ \\
\hline John Day Dam OR Shore & $\mathrm{Pu}-239 / 240$ & 0.001 & 0.001 & 0.006 & 0.001 & $\mathrm{DOH}$ \\
\hline John Day Dam WA Shore & $\mathrm{Pu}-239 / 240$ & 0.006 & 0.003 & 0.006 & & $\mathrm{DOH}$ \\
\hline McNary 2/3 OR Shore & Pu-239/240 & 0.009 & 0.004 & 0.006 & & $\mathrm{DOH}$ \\
\hline McNary 2/3 OR Shore & $\mathrm{Pu}-239 / 240$ & 0.013 & 0.004 & 0.006 & & $\mathrm{DOH}$ \\
\hline McNary 2/3 OR Shore & Pu-239/240 & 0.00954 & 0.0019 & & 0.0001 & PNNL \\
\hline McNary 2/3 OR Shore & Pu-239/240 & 0.0104 & 0.0018 & & 0.0002 & PNNL \\
\hline McNary OR Beach & $\mathrm{Pu}-239 / 240$ & 0.002 & 0.002 & 0.006 & 0.002 & $\mathrm{DOH}$ \\
\hline McNary OR Shore & Pu-239/240 & 0.008 & 0.004 & 0.006 & 0.005 & $\mathrm{DOH}$ \\
\hline McNary WA Beach & Pu-239/240 & 0.002 & 0.002 & 0.006 & 0.003 & $\mathrm{DOH}$ \\
\hline McNary WA Shore & $\mathrm{Pu}-239 / 240$ & 0.01 & 0.004 & 0.006 & & $\mathrm{DOH}$ \\
\hline Priest Rapids Dam Grant Co. Side & $\mathrm{Pu}-239 / 240$ & 0.0116 & 0.0023 & & 0.0001 & PNNL \\
\hline Priest Rapids Dam Yakima Co. Side & $\mathrm{Pu}-239 / 240$ & 0.00956 & 0.0023 & & 0.0006 & PNNL \\
\hline
\end{tabular}


Table B.1. (contd)

\begin{tabular}{|c|c|c|c|c|c|c|}
\hline Site & Analyte & Result & Error $^{(a)}$ & $\operatorname{LLD}^{(\mathrm{b})}$ & $\mathrm{MDA}^{(\mathrm{c})}$ & Agency \\
\hline Bonneville Dam OR Shore & Ru-106 & 0.246 & 0.3 & & 0.542 & PNNL \\
\hline Dalles Dam OR Shore & Ru-106 & -0.219 & 0.26 & & 0.421 & PNNL \\
\hline John Day Dam Mid-River & Ru-106 & -0.266 & 0.26 & & 0.417 & PNNL \\
\hline McNary 2/3 OR Shore & Ru-106 & -0.0878 & 0.19 & & 0.326 & PNNL \\
\hline McNary 2/3 OR Shore & Ru-106 & 0.0634 & 0.25 & & 0.45 & PNNL \\
\hline Priest Rapids Dam Grant Co. Side & Ru-106 & 0.00343 & 0.1 & & 0.18 & PNNL \\
\hline Priest Rapids Dam Yakima Co. Side & Ru-106 & 0.015 & 0.083 & & 0.145 & PNNL \\
\hline Bonneville Dam OR Shore & Sb-125 & 0.034 & 0.081 & & 0.142 & PNNL \\
\hline Dalles Dam OR Shore & Sb-125 & -0.0255 & 0.074 & & 0.126 & PNNL \\
\hline John Day Dam Mid-River & Sb-125 & 0.0322 & 0.072 & & 0.125 & PNNL \\
\hline McNary 2/3 OR Shore & Sb-125 & 0.0109 & 0.074 & & 0.128 & PNNL \\
\hline McNary 2/3 OR Shore & Sb-125 & 0.0233 & 0.059 & & 0.103 & PNNL \\
\hline Priest Rapids Dam Grant Co. Side & Sb-125 & 0.0165 & 0.03 & & 0.0522 & PNNL \\
\hline Priest Rapids Dam Yakima Co. Side & Sb-125 & 0.0044 & 0.026 & & 0.0448 & PNNL \\
\hline Bonneville Beach (OR) & Sr-90 & 0.011 & 0.004 & 0.003 & 0.007 & $\mathrm{DOH}$ \\
\hline Bonneville Beach (OR) & Sr-90 & 0.022 & 0.020 & & 0.0328 & PNNL \\
\hline Bonneville Dam OR Shore & Sr-90 & 0.0045 & 0.018 & & 0.0334 & PNNL \\
\hline Bonneville Dam OR Shore & Sr-90 & 0.011 & 0.004 & 0.003 & 0.007 & $\mathrm{DOH}$ \\
\hline Dalles Dam OR Shore & Sr-90 & 0.0341 & 0.022 & & 0.0353 & PNNL \\
\hline Dalles Dam OR Shore & Sr-90 & 0.011 & 0.004 & 0.003 & 0.006 & $\mathrm{DOH}$ \\
\hline Dalles Dam WA Shore & Sr-90 & 0.0122 & 0.020 & & 0.0357 & PNNL \\
\hline Dalles Dam WA Shore & Sr-90 & 0.006 & 0.003 & 0.003 & 0.005 & $\mathrm{DOH}$ \\
\hline John Day Dam Mid-River & Sr-90 & 0.0061 & 0.022 & & 0.0412 & PNNL \\
\hline John Day Dam Mid-River & Sr-90 & 0.018 & 0.006 & 0.003 & 0.008 & $\mathrm{DOH}$ \\
\hline John Day Dam OR Shore & Sr-90 & 0.0298 & 0.018 & & 0.0282 & PNNL \\
\hline John Day Dam OR Shore & Sr-90 & 0.032 & 0.007 & 0.003 & 0.009 & $\mathrm{DOH}$ \\
\hline John Day Dam WA Shore & Sr-90 & 0.0258 & 0.023 & & 0.0398 & PNNL \\
\hline John Day Dam WA Shore & Sr-90 & 0.019 & 0.004 & 0.003 & 0.005 & $\mathrm{DOH}$ \\
\hline McNary 2/3 OR Shore & Sr-90 & 0.013 & 0.003 & 0.003 & 0.004 & $\mathrm{DOH}$ \\
\hline McNary 2/3 OR Shore & Sr-90 & 0.015 & 0.004 & 0.003 & 0.005 & $\mathrm{DOH}$ \\
\hline McNary 2/3 OR Shore & Sr-90 & 0.0162 & 0.024 & & 0.0427 & PNNL \\
\hline McNary 2/3 OR Shore & Sr-90 & 0.0124 & 0.022 & & 0.0397 & PNNL \\
\hline McNary OR Beach & Sr-90 & 0.001 & 0.002 & 0.003 & 0.005 & $\mathrm{DOH}$ \\
\hline McNary OR Beach & Sr-90 & -0.007 & 0.021 & & 0.0396 & PNNL \\
\hline McNary OR Shore & Sr-90 & 0.017 & 0.004 & 0.003 & 0.006 & $\mathrm{DOH}$ \\
\hline McNary OR Shore & Sr-90 & -0.0061 & 0.018 & & 0.0339 & PNNL \\
\hline
\end{tabular}


Table B.1. (contd)

\begin{tabular}{|c|c|c|c|c|c|c|}
\hline Site & Analyte & Result & Error $^{(a)}$ & $\operatorname{LLD}^{(\mathrm{b})}$ & $\mathrm{MDA}^{(\mathrm{c})}$ & Agency \\
\hline McNary WA Beach & Sr-90 & 0.002 & 0.002 & 0.003 & 0.005 & $\mathrm{DOH}$ \\
\hline McNary WA Beach & Sr-90 & -0.0069 & 0.019 & & 0.0361 & PNNL \\
\hline McNary WA Shore & Sr-90 & 0.01 & 0.003 & 0.003 & 0.004 & $\mathrm{DOH}$ \\
\hline Priest Rapids Dam Grant Co Side & Sr-90 & 0.0104 & 0.024 & & 0.0435 & PNNL \\
\hline Priest Rapids Dam Yakima Co Side & Sr-90 & 0.0033 & 0.021 & & 0.0384 & PNNL \\
\hline Bonneville Beach (OR) & Total U & 2.29 & 0.15 & 0.09 & 0.04 & $\mathrm{DOH}$ \\
\hline Bonneville Dam OR Shore & Total U & 0.9 & 0.09 & 0.09 & 0.04 & $\mathrm{DOH}$ \\
\hline Dalles Dam OR Shore & Total U & 2.21 & 0.15 & 0.09 & 0.04 & $\mathrm{DOH}$ \\
\hline Dalles Dam WA Shore & Total U & 3.56 & 0.19 & 0.09 & 0.04 & $\mathrm{DOH}$ \\
\hline John Day Dam Mid-River & Total U & 2.8 & 0.2 & 0.09 & & $\mathrm{DOH}$ \\
\hline John Day Dam OR Shore & Total U & 2.3 & 0.2 & 0.09 & & $\mathrm{DOH}$ \\
\hline John Day Dam WA Shore & Total U & 2.7 & 0.2 & 0.09 & & $\mathrm{DOH}$ \\
\hline McNary 2/3 OR Shore & Total U & 3 & 0.2 & 0.09 & & $\mathrm{DOH}$ \\
\hline McNary 2/3 OR Shore & Total U & 3 & 0.2 & 0.09 & & $\mathrm{DOH}$ \\
\hline McNary OR Beach & Total U & 0.92 & 0.11 & 0.09 & & $\mathrm{DOH}$ \\
\hline McNary OR Shore & Total U & 3 & 0.2 & 0.09 & & $\mathrm{DOH}$ \\
\hline McNary WA Beach & Total U & 0.76 & 0.1 & 0.09 & & $\mathrm{DOH}$ \\
\hline McNary WA Shore & Total U & 2.1 & 0.2 & 0.09 & 0.053 & $\mathrm{DOH}$ \\
\hline Bonneville Beach (OR) & $\mathrm{U}-234$ & 1.21 & 0.11 & 0.063 & 0.03 & $\mathrm{DOH}$ \\
\hline Bonneville Dam OR Shore & U-234 & 0.697 & 0.12 & & 0.0135 & PNNL \\
\hline Bonneville Dam OR Shore & U-234 & 0.5 & 0.07 & 0.063 & 0.03 & $\mathrm{DOH}$ \\
\hline Dalles Dam OR Shore & $\mathrm{U}-234$ & 0.674 & 0.11 & & 0.0116 & PNNL \\
\hline Dalles Dam OR Shore & $\mathrm{U}-234$ & 1.2 & 0.11 & 0.063 & 0.03 & $\mathrm{DOH}$ \\
\hline Dalles Dam WA Shore & $\mathrm{U}-234$ & 1.74 & 0.14 & 0.063 & 0.04 & $\mathrm{DOH}$ \\
\hline John Day Dam Mid-River & $\mathrm{U}-234$ & 0.946 & 0.16 & & 0.0239 & PNNL \\
\hline John Day Dam Mid-River & $\mathrm{U}-234$ & 1.4 & 0.1 & 0.063 & & $\mathrm{DOH}$ \\
\hline John Day Dam OR Shore & $\mathrm{U}-234$ & 1.2 & 0.1 & 0.063 & & $\mathrm{DOH}$ \\
\hline John Day Dam WA Shore & $\mathrm{U}-234$ & 1.4 & 0.1 & 0.063 & & $\mathrm{DOH}$ \\
\hline McNary 2/3 OR Shore & $\mathrm{U}-234$ & 1.4 & 0.1 & 0.063 & & $\mathrm{DOH}$ \\
\hline McNary 2/3 OR Shore & $\mathrm{U}-234$ & 1.5 & 0.1 & 0.063 & & $\mathrm{DOH}$ \\
\hline McNary 2/3 OR Shore & $\mathrm{U}-234$ & 0.677 & 0.12 & & 0.0053 & PNNL \\
\hline McNary 2/3 OR Shore & $\mathrm{U}-234$ & 0.732 & 0.13 & & 0.0027 & PNNL \\
\hline McNary OR Beach & $\mathrm{U}-234$ & 0.45 & 0.07 & 0.063 & & $\mathrm{DOH}$ \\
\hline McNary OR Shore & $\mathrm{U}-234$ & 1.6 & 0.2 & 0.063 & & $\mathrm{DOH}$ \\
\hline McNary WA Beach & $\mathrm{U}-234$ & 0.39 & 0.07 & 0.063 & & $\mathrm{DOH}$ \\
\hline
\end{tabular}


Table B.1. (contd)

\begin{tabular}{|c|c|c|c|c|c|c|}
\hline Site & Analyte & Result & Error $^{(a)}$ & $\operatorname{LLD}^{(\mathrm{b})}$ & $\mathrm{MDA}^{(\mathrm{c})}$ & Agency \\
\hline McNary WA Shore & U-234 & 1.1 & 0.1 & 0.063 & 0.035 & $\mathrm{DOH}$ \\
\hline Priest Rapids Dam Grant Co. Side & U-234 & 0.727 & 0.12 & & 0.0066 & PNNL \\
\hline Priest Rapids Dam Yakima Co. Side & $\mathrm{U}-234$ & 0.669 & 0.12 & & 0.0019 & PNNL \\
\hline Bonneville Beach (OR) & $\mathrm{U}-235$ & 0.051 & 0.022 & 0.01 & 0.007 & $\mathrm{DOH}$ \\
\hline Bonneville Dam OR Shore & U-235 & 0.0201 & 0.0099 & & 0.0093 & PNNL \\
\hline Bonneville Dam OR Shore & U-235 & 0.017 & 0.013 & 0.01 & 0.007 & DOH \\
\hline Dalles Dam OR Shore & U-235 & 0.0103 & 0.0072 & & 0.0084 & PNNL \\
\hline Dalles Dam OR Shore & U-235 & 0.046 & 0.021 & 0.01 & 0.007 & $\mathrm{DOH}$ \\
\hline Dalles Dam WA Shore & U-235 & 0.062 & 0.025 & 0.01 & 0.007 & DOH \\
\hline John Day Dam Mid-River & U-235 & 0.0242 & 0.014 & & 0.0158 & PNNL \\
\hline John Day Dam Mid-River & U-235 & 0.041 & 0.026 & 0.01 & & DOH \\
\hline John Day Dam OR Shore & U-235 & 0.027 & 0.024 & 0.01 & & $\mathrm{DOH}$ \\
\hline John Day Dam WA Shore & U-235 & 0.037 & 0.026 & 0.01 & & DOH \\
\hline McNary 2/3 OR Shore & U-235 & 0.03 & 0.027 & 0.01 & & $\mathrm{DOH}$ \\
\hline McNary 2/3 OR Shore & U-235 & 0.03 & 0.027 & 0.01 & & $\mathrm{DOH}$ \\
\hline McNary 2/3 OR Shore & U-235 & 0.0225 & 0.011 & & 0.0027 & PNNL \\
\hline McNary 2/3 OR Shore & U-235 & 0.0257 & 0.0098 & & 0.002 & PNNL \\
\hline McNary OR Beach & U-235 & 0.015 & 0.022 & 0.01 & & $\mathrm{DOH}$ \\
\hline McNary OR Shore & U-235 & 0.027 & 0.032 & 0.01 & & $\mathrm{DOH}$ \\
\hline McNary WA Beach & U-235 & 0.011 & 0.021 & 0.01 & & $\mathrm{DOH}$ \\
\hline McNary WA Shore & U-235 & 0.042 & 0.023 & 0.01 & 0.025 & $\mathrm{DOH}$ \\
\hline Priest Rapids Dam Grant Co. Side & U-235 & 0.0217 & 0.0091 & & 0.0052 & PNNL \\
\hline Priest Rapids Dam Yakima Co. Side & U-235 & 0.0155 & 0.0077 & & 0.0052 & PNNL \\
\hline Bonneville Beach (OR) & U-238 & 0.97 & 0.1 & 0.054 & 0.03 & $\mathrm{DOH}$ \\
\hline Bonneville Dam OR Shore & U-238 & 0.562 & 0.098 & & 0.0093 & PNNL \\
\hline Bonneville Dam OR Shore & $\mathrm{U}-238$ & 0.38 & 0.06 & 0.054 & 0.03 & $\mathrm{DOH}$ \\
\hline Dalles Dam OR Shore & U-238 & 0.516 & 0.09 & & 0.0091 & PNNL \\
\hline Dalles Dam OR Shore & $\mathrm{U}-238$ & 0.94 & 0.09 & 0.054 & 0.03 & $\mathrm{DOH}$ \\
\hline Dalles Dam WA Shore & U-238 & 1.73 & 0.13 & 0.054 & 0.02 & $\mathrm{DOH}$ \\
\hline John Day Dam Mid-River & $\mathrm{U}-238$ & 0.699 & 0.12 & & 0.0211 & PNNL \\
\hline John Day Dam Mid-River & $\mathrm{U}-238$ & 1.2 & 0.1 & 0.054 & & $\mathrm{DOH}$ \\
\hline John Day Dam OR Shore & $\mathrm{U}-238$ & 1.1 & 0.1 & 0.054 & & $\mathrm{DOH}$ \\
\hline John Day Dam WA Shore & U-238 & 1.2 & 0.1 & 0.054 & & $\mathrm{DOH}$ \\
\hline McNary 2/3 OR Shore & $\mathrm{U}-238$ & 1.4 & 0.1 & 0.054 & & $\mathrm{DOH}$ \\
\hline McNary 2/3 OR Shore & U-238 & 1.4 & 0.1 & 0.054 & & $\mathrm{DOH}$ \\
\hline McNary 2/3 OR Shore & U-238 & 0.58 & 0.1 & & 0.002 & PNNL \\
\hline McNary 2/3 OR Shore & $\mathrm{U}-238$ & 0.593 & 0.11 & & 0.0027 & PNNL \\
\hline
\end{tabular}


Table B.1. (contd)

\begin{tabular}{|c|c|c|c|c|c|c|}
\hline Site & Analyte & Result & Error $^{(a)}$ & $\operatorname{LLD}^{(b)}$ & $\mathrm{MDA}^{(\mathrm{c})}$ & Agency \\
\hline McNary OR Beach & $\mathrm{U}-238$ & 0.42 & 0.07 & 0.054 & & $\mathrm{DOH}$ \\
\hline McNary OR Shore & $\mathrm{U}-238$ & 1.3 & 0.2 & 0.054 & & $\mathrm{DOH}$ \\
\hline McNary WA Beach & $\mathrm{U}-238$ & 0.35 & 0.07 & 0.054 & & $\mathrm{DOH}$ \\
\hline McNary WA Shore & U-238 & 0.96 & 0.1 & 0.054 & 0.035 & $\mathrm{DOH}$ \\
\hline Priest Rapids Dam Grant Co. Side & U-238 & 0.659 & 0.11 & & 0.0066 & PNNL \\
\hline Priest Rapids Dam Yakima Co. Side & $\mathrm{U}-238$ & 0.576 & 0.1 & & 0.0066 & PNNL \\
\hline $\begin{array}{l}\text { (a) } \mathrm{DOH} \text { and PNNL errors are repor } \\
\text { (b) } \mathrm{LLD}=\text { Lower limit of detection. } \\
\text { (c) } \mathrm{MDA}=\text { Minimal detectable activ } \\
\text { Co }=\text { County. } \\
\text { ODOE }=\text { Oregon Department of EI } \\
\text { PNNL = Pacific Northwest Nation } \\
\text { DOH }=\text { Washington State Depart }\end{array}$ & $\begin{array}{l}\text { aboratory. } \\
\text { of Health. }\end{array}$ & errors ar & ted as 3-s & & & \\
\hline
\end{tabular}


Table B.2. Concentrations of Metals in Columbia River Sediment ( $\mu$ g/g dry wt.)

\begin{tabular}{|c|c|c|c|c|c|c|c|c|c|c|c|c|c|c|}
\hline \multicolumn{15}{|c|}{ WDOE Proposed Standards } \\
\hline & & & $\mathrm{Al}$ & $\mathrm{Sb}$ & As & $\mathrm{Ba}$ & $\mathrm{Be}$ & $\mathrm{Cd}$ & $\mathrm{Ca}$ & $\mathrm{Cr}$ & Co & $\mathrm{Cu}$ & $\mathrm{Fe}$ & $\mathrm{Pb}$ \\
\hline Proposed WA S & iment Quality Standard ${ }^{(\mathrm{a})}$ & & -- & 0.4 & 20 & -- & -- & 0.6 & -- & 95 & 80 & -- & -- & 335 \\
\hline Proposed WA S & iment Cleanup Screening Le & & -- & 0.6 & 51 & -- & -- & 1.0 & -- & 100 & 830 & -- & -- & 430 \\
\hline \multicolumn{15}{|c|}{ WDOE Results } \\
\hline Sample No. & Location & Date & $\mathrm{Al}$ & $\mathrm{Sb}$ & As & $\mathrm{Ba}$ & $\mathrm{Be}$ & $\mathrm{Cd}$ & $\mathrm{Ca}$ & $\mathrm{Cr}$ & Co & $\mathrm{Cu}$ & $\mathrm{Fe}$ & $\mathrm{Pb}$ \\
\hline B17BB8 & Bonneville OR Shore & $08 / 07 / 03$ & 11,000 & 4.3 & 4.8 & 120 & 1.1 & 1.1 & 4,400 & 16 & 12 & 23 & 24,000 & 13 \\
\hline B17BB5 & Bonneville OR Beach & $08 / 07 / 03$ & 11,000 & 3 & 1.5 & 79 & 0.74 & 1.5 & 4,500 & 15 & 21 & 16 & 42,000 & 4 \\
\hline B17B93 & Dallas Dam OR Shore & $08 / 07 / 03$ & 12,000 & 4.5 & 4.6 & 120 & 1.1 & 1.4 & 4,800 & 18 & 13 & 23 & 27,000 & 14 \\
\hline B17B99 & Dallas Dam WA Shore & $08 / 08 / 03$ & 5,500 & 2.6 & 3.3 & 72 & 0.65 & 0.65 & 3,100 & 9.4 & 10 & 7.5 & 22,000 & 7.3 \\
\hline B17B84 & John Day WA Shore & 08/08/03 & 18,000 & 5.5 & 7.4 & 170 & 1.4 & 2.4 & 5,900 & 25 & 19 & 34 & 37,000 & 22 \\
\hline B17B81 & John Day Mid River & 08/08/03 & 19,000 & 6.1 & 8.6 & 170 & 1.5 & 2.3 & 6,100 & 27 & 18 & 35 & 37,000 & 23 \\
\hline B17B78 & John Day Dam OR Shore & 08/08/03 & 22,000 & 5.9 & 9.5 & 210 & 1.5 & 2.5 & 6,800 & 30 & 22 & 46 & 44,000 & 27 \\
\hline B17B60 & McNary Dam OR Shore & $08 / 08 / 03$ & 17,000 & 5.1 & 7.6 & 150 & 1.3 & 1.9 & 5,800 & 26 & 17 & 31 & 34,000 & 20 \\
\hline B17B57 & McNary Dam OR Beach & 08/08/03 & 2,900 & 2.4 & 2.1 & 53 & 0.6 & 1.2 & 3,500 & 3.7 & 12 & 7.1 & 24,000 & 2.1 \\
\hline B17B65 & McNary 2/3 OR Shore & 08/08/03 & 11,000 & 3.7 & 5.8 & 110 & 0.93 & 1.4 & 4,700 & 21 & 13 & 19 & 27,000 & 18 \\
\hline B17B66 (dup) & McNary 2/3 OR Shore & 08/08/03 & 11,000 & 3.5 & 5.9 & 110 & 0.88 & 1.4 & 4,500 & 20 & 13 & 19 & 26,000 & 18 \\
\hline B17B72 & McNary Dam WA Beach & $08 / 08 / 03$ & 3,800 & 2.5 & 1.8 & 68 & 0.62 & 1.2 & 3,700 & 5.7 & 13 & 8.2 & 27,000 & 2.5 \\
\hline B17B67 & McNary Dam WA Shore & $08 / 08 / 03$ & 9,100 & 3.4 & 4.3 & 92 & 0.84 & 1.0 & 4,000 & 16 & 11 & 15 & 24,000 & 14 \\
\hline \multicolumn{15}{|c|}{ PNNL Results } \\
\hline B17BK5 & Bonneville Dam OR Shore & $08 / 07 / 03$ & NA & 0.84 & 5.96 & NA & 1.60 & 0.88 & NA & 57.3 & NA & 32.1 & NA & 18.7 \\
\hline B17BK5 (dup) & Bonneville Dam OR Shore & $08 / 07 / 03$ & NA & 0.86 & 6.09 & NA & 1.55 & 0.89 & NA & 59.0 & NA & 32.3 & NA & 18.4 \\
\hline B17BK1 & Dalles Dam Mid. River & 08/07/03 & NA & 0.6 & 5.57 & NA & 1.60 & 1.21 & NA & 57.2 & NA & 30.8 & NA & 17.6 \\
\hline B17BJ7 & John Day Dam Mid. River & 08/08/03 & NA & 0.82 & 9.90 & NA & 1.89 & 2.02 & NA & 69.3 & NA & 40.2 & NA & 25.6 \\
\hline $\mathrm{B} 17 \mathrm{BJ} 3$ & McNary 2/3 OR Shore & 08/08/03 & NA & 0.7 & 7.55 & NA & 1.79 & 1.48 & NA & 73.2 & NA & 26.7 & NA & 24.7 \\
\hline \multicolumn{15}{|c|}{ SESP Results } \\
\hline B17704 & PRD-Grant Co. Side & 07/14/03 & NA & 0.91 & 9.73 & NA & 1.56 & 8.93 & NA & 86.9 & NA & 50.0 & NA & 49.6 \\
\hline B17704 (dup) & PRD-Grant Co. Side & 07/14/03 & NA & 0.9 & 9.50 & NA & 1.47 & 9.02 & NA & 86.9 & NA & 49.8 & NA & 50.2 \\
\hline B17702 & PRD-Yakima Co. Side & 07/14/03 & NA & 0.9 & 9.20 & NA & 1.50 & 5.99 & NA & 92.1 & NA & 45.9 & NA & 54.2 \\
\hline
\end{tabular}


Table B.2. (contd)

\begin{tabular}{|c|c|c|c|c|c|c|c|c|c|c|c|c|c|}
\hline \multicolumn{14}{|c|}{ 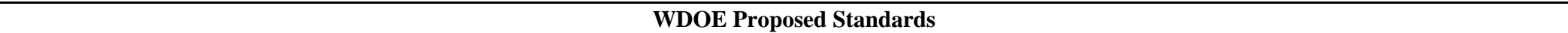 } \\
\hline & & & $\mathrm{Mg}$ & $\mathrm{Mn}$ & $\mathrm{Ni}$ & $\mathrm{K}$ & Se & $\mathrm{Ag}$ & $\mathrm{Na}$ & $\mathrm{Tl}$ & $\mathrm{V}$ & $\mathrm{Zn}$ & $\mathrm{Hg}$ \\
\hline Proposed WA St & iment Quality Standard ${ }^{(\mathrm{a})}$ & & "-- & "-- & (60 & "-- & "-- & 2.0 & "-- & --- & "-- & 140 & (20.50 \\
\hline Proposed WA St & iment Cleanup Screening Level ${ }^{\mathrm{a}}$ & & $\overline{--}$ & -- & 70 & $\overline{--}$ & $\overline{--}$ & 2.5 & -- & -- & -- & 160 & 0.75 \\
\hline \multicolumn{14}{|c|}{ WDOE Results } \\
\hline Sample No. & Location & Date & $\mathrm{Mg}$ & $\mathrm{Mn}$ & $\mathrm{Ni}$ & $\mathrm{K}$ & Se & $\mathrm{Ag}$ & $\mathrm{Na}$ & $\mathrm{Tl}$ & $\mathrm{V}$ & $\mathrm{Zn}$ & $\mathrm{Hg}$ \\
\hline B17BB8 & Bonneville OR Shore & $08 / 07 / 03$ & (4,200 & 2510 & 16 & 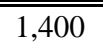 & 1.3 & 2.1 & 340 & 2.1 & 58 & 140 & 0.21 \\
\hline B17BB5 & Bonneville OR Beach & $08 / 07 / 03$ & 7,000 & 450 & 30 & 450 & 1.5 & 1.5 & 390 & 3 & 120 & 64 & 0.15 \\
\hline B17B93 & Dallas Dam OR Shore & $08 / 07 / 03$ & 4,100 & 400 & 16 & 1,500 & 1.1 & 2.2 & 330 & 2.2 & 62 & 160 & 0.22 \\
\hline B17B99 & Dallas Dam WA Shore & $08 / 08 / 03$ & 3,100 & 370 & 9.7 & 830 & 0.96 & 1.3 & 170 & 1.3 & 62 & 84 & 0.13 \\
\hline B17B84 & John Day WA Shore & $08 / 08 / 03$ & 6,400 & 680 & 24 & 2,500 & 1.6 & 2.8 & 320 & 2.8 & 73 & 240 & 0.28 \\
\hline B17B81 & John Day Mid River & $08 / 08 / 03$ & 6,700 & 770 & 25 & 2,500 & 1.5 & 3 & 320 & 3 & 71 & 250 & 0.3 \\
\hline B17B78 & John Day Dam OR Shore & $08 / 08 / 03$ & 7,500 & 840 & 29 & 3,000 & 1.5 & 2.9 & 370 & 2.9 & 87 & 270 & 0.29 \\
\hline B17B60 & McNary Dam OR Shore & $08 / 08 / 03$ & 6,700 & 640 & 25 & 2,300 & 1.3 & 2.5 & 280 & 2.5 & 64 & 220 & 0.25 \\
\hline B17B57 & McNary Dam OR Beach & $08 / 08 / 03$ & 3,200 & 280 & 6.1 & 490 & 1.2 & 1.2 & 130 & 2.4 & 72 & 53 & 0.18 \\
\hline B17B65 & McNary 2/3 OR Shore & $08 / 08 / 03$ & 5,500 & 630 & 20 & 1,700 & 0.93 & 1.9 & 220 & 1.9 & 50 & 240 & 0.19 \\
\hline B17B66 (dup) & McNary 2/3 OR Shore & \begin{tabular}{|l|l|}
$08 / 08 / 03$ \\
\end{tabular} & 5,300 & 600 & 19 & 1,700 & 0.88 & 1.8 & 220 & 1.8 & 48 & 230 & 0.12 \\
\hline B17B72 & McNary Dam WA Beach & 08/08/03 & 4,200 & 450 & 15 & 1,400 & 0.84 & 1.7 & 210 & 1.7 & 47 & 160 & NA \\
\hline B17B67 & McNary Dam WA Shore & $08 / 08 / 03$ & 3,900 & 410 & 7.9 & 660 & 1.2 & 1.2 & 140 & 2.5 & 77 & 46 & NA \\
\hline \multicolumn{14}{|c|}{ PNNL Results } \\
\hline B17BK5 & Bonneville Dam OR Shore & $08 / 07 / 03$ & NA & NA & 25 & NA & 0.477 & 0.314 & NA & 0.445 & NA & 175 & 0.512 \\
\hline B17BK5 (dup) & Bonneville Dam OR Shore & $08 / 07 / 03$ & NA & $\mathrm{NA}$ & 27 & NA & 0.477 & 0.319 & NA & 0.462 & NA & 180 & 0.168 \\
\hline B17BK1 & Dalles Dam Mid. River & $08 / 07 / 03$ & NA & NA & 24.0 & NA & 0.477 & 0.337 & NA & 0.535 & NA & 179 & 0.0533 \\
\hline B17BJ7 & John Day Dam Mid. River & \begin{tabular}{|l|}
$08 / 08 / 03$ \\
\end{tabular} & NA & NA & 32 & NA & 0.477 & 0.433 & NA & 0.694 & NA & 261 & 0.105 \\
\hline B17BJ3 & McNary 2/3 OR Shore & 08/08/03 & NA & NA & 30 & NA & 0.477 & 0.438 & NA & 0.729 & NA & 276 & 0.0927 \\
\hline \multicolumn{14}{|c|}{ SESP Results } \\
\hline B17704 & PRD-Grant Co. Side & 07/14/03 & NA & NA & 42 & NA & 0.477 & 0.484 & NA & 1.72 & NA & 591 & 0.167 \\
\hline B17704 (dup) & PRD-Grant Co. Side & $07 / 14 / 03$ & NA & NA & 42 & NA & 0.477 & 0.469 & NA & 1.74 & NA & 594 & 0.171 \\
\hline B17702 & PRD-Yakima Co. Side & 07/14/03 & NA & $\mathrm{NA}$ & 47 & NA & 0.477 & 0.447 & NA & 1.15 & NA & 495 & 0.187 \\
\hline
\end{tabular}


Table B.3. Simultaneously Extracted Metal/Acid Volatile Sulfide (SEM/AVS) Concentrations ( $\mu \mathrm{mol} / \mathrm{g}$ dry wt.) for Columbia River Sediment

\begin{tabular}{|c|c|c|c|c|c|c|c|c|c|c|}
\hline Sample No. & Location & Date & $\begin{array}{c}\text { \% Dry } \\
\text { Weight }\end{array}$ & AVS & SEM Cd & SEM Cu & SEM Hg & SEM Ni & SEM Pb & SEM Zn \\
\hline B17BK3 & Bonneville Dam OR Shore & 8/7/2003 & 49.0 & 3.631 & 0.0053 & 0.195 & 0.000009 & 0.103 & 0.054 & 1.487 \\
\hline B17BJ9 & Dalles Dam OR. Shore & $8 / 7 / 2003$ & 48.9 & 4.166 & 0.0083 & 0.205 & 0.000016 & 0.097 & 0.059 & 1.791 \\
\hline B17BJ9 (dup) & Dalles Dam OR. Shore & 8/7/2003 & 48.9 & 3.420 & 0.0080 & 0.198 & 0.000014 & 0.094 & 0.057 & 1.703 \\
\hline B17BK2 & Dalles Dam WA Shore & 8/7/2003 & 73.8 & 0.051 & 0.0033 & 0.068 & 0.000029 & 0.046 & 0.033 & 0.752 \\
\hline B17BJ5 & John Day Dam OR Shore & 8/8/2003 & 36.7 & 3.292 & 0.0143 & 0.419 & 0.000013 & 0.174 & 0.105 & 2.735 \\
\hline B17BJ6 & John Day Dam Mid. River & 8/8/2003 & 38.5 & 7.575 & 0.0143 & 0.286 & 0.000014 & 0.142 & 0.093 & 2.835 \\
\hline B17BJ8 & John Day Dam WA Shore & 8/8/2003 & 51.8 & 8.385 & 0.0161 & 0.274 & 0.000007 & 0.158 & 0.087 & 2.434 \\
\hline B17BJ1 & McNary OR Shore & 8/8/2003 & 39.3 & 4.900 & 0.0129 & 0.261 & 0.000019 & 0.155 & 0.083 & 2.388 \\
\hline B17BJ2 & McNary 2/3 OR Shore & 8/8/2003 & 57.7 & 0.118 & 0.0104 & 0.181 & 0.000161 & 0.098 & 0.074 & 2.224 \\
\hline B17BJ4 & McNary WA Shore & 8/8/2003 & 59.9 & 0.069 & 0.0090 & 0.145 & 0.000115 & 0.081 & 0.061 & 1.717 \\
\hline B17BJ4 (dup) & McNary WA Shore & 8/8/2003 & 59.9 & 0.075 & 0.0087 & 0.142 & 0.000120 & 0.068 & 0.060 & 1.704 \\
\hline \multicolumn{2}{|c|}{ Detection Limit (mean DL used for AVS) } & & & 0.123 & 0.0001 & 0.0001 & 0.0000003 & 0.0001 & 0.00002 & 0.0009 \\
\hline B17703 & Priest Rapids Grant Co. Side & $7 / 14 / 2003$ & 47.2 & 7.47 & 0.0770 & 0.3509 & 0.0000065 & 0.157 & 0.189 & 8.379 \\
\hline B17703 (dup) & Priest Rapids Grant Co. Side & $7 / 14 / 2003$ & 45.2 & 7.09 & 0.0743 & 0.38327 & 0.0000201 & 0.178 & 0.185 & 8.193 \\
\hline B17701 & Priest Rapids Yakima Co. Side & $7 / 14 / 2003$ & 51.1 & 3.83 & 0.0442 & 0.46107 & 0.0000083 & 0.210 & 0.184 & 6.014 \\
\hline B17701(dup) & Priest Rapids Yakima Co. Side & $7 / 14 / 2003$ & 51.1 & 3.61 & 0.0430 & 0.46193 & 0.0000107 & 0.210 & 0.179 & 5.950 \\
\hline \multicolumn{2}{|c|}{ Bold = Value was below detection limit. } & & & 0.086 & 0.00006 & 0.00008 & 0.0000002 & 0.00005 & 0.00002 & 0.001 \\
\hline
\end{tabular}


Table B.4. Analytical Detection Limits ( $\mu \mathrm{g} / \mathrm{kg}$ dry wt.) for Pesticides, PCBs, and Semivolatile Organic Compounds in Columbia River Sediment

\begin{tabular}{|c|c|c|c|c|c|}
\hline Organochlorine Pesticides & MDL $\mu \mathrm{g} / \mathrm{kg}$ & Semi-Volatile Organics & MDL $\mu \mathrm{g} / \mathrm{kg}$ & Semivolatile Organics & MDL $\mu \mathrm{g} / \mathrm{kg}$ \\
\hline Alpha-BHC & 1.7 & Pyridine & 330 & 2,6-Dinitrotoluene & 330 \\
\hline Lindane (Gamma-BHC) & 1.7 & N-Nitrosodimethytlamine & 330 & Acenaphthalene & 330 \\
\hline Beta-BHC & 1.7 & Aniline & 830 & 3-Nitroaniline & 1,700 \\
\hline Delta-BHC & 1.7 & Phenol & 330 & Acenaphthene & 330 \\
\hline Hepatachlor & 1.7 & Bis(2-chloroethyl)ether & 330 & 2,4-Dinitrophenol & 1,700 \\
\hline Aldrin & 1.7 & 2-Chlorophenol & 330 & 4-Nitrophenol & 1,700 \\
\hline Hepatachlor epoxide & 1.7 & 1,3-Dichlorobenzene & 330 & Dibenzofuran & 330 \\
\hline Gamma-chlordane & 1.7 & 1,4-Dichlorobenzene & 330 & 2,4-Dinitrotoluene & 330 \\
\hline Alpha-chlordane & 1.7 & 1,2-Dichlorobenzene & 330 & Diethylphthalate & 330 \\
\hline 4,4- DDE & 1.7 & Benzyl alcohol & 330 & Fluorene & 330 \\
\hline Endosulfan I & 1.7 & Bis(2-chloroisopropyl)ether & 330 & 4-Chlorophenyl phenyl ether & 330 \\
\hline Dieldrin & 1.7 & 2-Methylphenol & 330 & 4-Nitroaniline & 1,700 \\
\hline Endrin & 1.7 & N-Nitroso-di-n-propylamine & 330 & Azobenzene & 330 \\
\hline 4,4-DDD & 1.7 & 4-Methylphenol & 330 & 4,6-Dinitro-2-methylphenol & 1,700 \\
\hline Endosulfan II & 1.7 & Hexachloroethane & 330 & N-nitrosodiphenylamine & 330 \\
\hline 4,4-DDT & 1.7 & Nitrobenzene & 330 & 4-Bromophenyl phenyl ether & 330 \\
\hline Endrin aldehyde & 1.7 & Isophorone & 330 & Hexachlorobenzene & 330 \\
\hline Methoxychlor & 8.3 & 2-Nitrophenol & 330 & 2,3,4,6-Tetrachlorophenol & 1,700 \\
\hline Endosulfan sulfate & 1.7 & 2,4-Dimethylphenol & 330 & Pentachlorophenol & 1,700 \\
\hline Endrin ketone & 1.7 & Bis(2-chloroethoxy)methane & 330 & Phenanthrene & 330 \\
\hline Toxaphene & 83 & 2,4-Dichlorophenol & 330 & Anthracene & 330 \\
\hline & & Benzoic Acid & 1700 & Carbazole & 330 \\
\hline \multicolumn{2}{|l|}{ PCBs } & 1,2,4,-Trichlorobenzene & 330 & Di-n-butyl phthalate & 330 \\
\hline Aroclor-1016 & 33 & Naphthalene & 330 & Fluoranthene & 330 \\
\hline Aroclor-1221 & 67 & 4-Chloroaniline & 330 & Pyrene & 330 \\
\hline Aroclor-1232 & 33 & Hexachlorobutadiene & 330 & Butyl benzyl phthalate & 330 \\
\hline
\end{tabular}


Table B.4. (contd)

\begin{tabular}{|c|c|c|c|c|c|}
\hline PCBs & MDL $\mu \mathrm{g} / \mathrm{kg}$ & Semi-Volatile Organics & MDL $\mu \mathrm{g} / \mathrm{kg}$ & Semivolatile Organics & MDL $\mu \mathrm{g} / \mathrm{kg}$ \\
\hline Aroclor-1242 & 33 & 4-Chloro-3-methylphenol & 330 & Benzo(a)anthracenene & 330 \\
\hline Aroclor-1248 & 33 & 2-Methylnaphthalene & 330 & 3,3-Dichlorobenzidine & 1,700 \\
\hline Aroclor-1254 & 33 & Hexachlorocyclopentadiene & 330 & Chrysene & 330 \\
\hline \multirow[t]{8}{*}{ Aroclor-1260 } & 33 & 2,4,6-Trichlorophenol & 330 & Bis(2-ethylhexyl)phthalate & 330 \\
\hline & & 2,4,5-Trichlorophenol & 330 & Di-n-octylphthalate & 330 \\
\hline & & 2-Chloronaphthalene & 330 & Benzo(b)fluoranthene & 330 \\
\hline & & 2-Nitroaniline & 1700 & Benzo(k)fluoranthene & 330 \\
\hline & & Dimethylphthalate & 330 & Benzo(a)pyrene & 330 \\
\hline & & & & Indeno(1,2,3-cd)pyrene & 330 \\
\hline & & & & Dibenzo(a,h)anthracene & 330 \\
\hline & & & & Benzo(g,h)perylene & 330 \\
\hline $\begin{array}{l}\text { MDL }=\text { Methc } \\
\text { PCB }=\text { Polyc }\end{array}$ & $\begin{array}{l}\text { iit. } \\
\text { enyl. }\end{array}$ & & & & \\
\hline
\end{tabular}


Table B.5. Semivolatile Organic Compounds in Columbia River Sediment (all values in $\mu \mathrm{g} / \mathrm{kg}$ dry wt.). All results were below the detection limits listed in Table B.4.

\begin{tabular}{|c|c|c|c|c|c|c|c|c|c|}
\hline \multirow[b]{2}{*}{ Analyte } & \multirow{2}{*}{$\begin{array}{l}\text { Proposed WA } \\
\text { Sediment } \\
\text { Quality } \\
\text { Standard (a) }\end{array}$} & \multirow{2}{*}{$\begin{array}{c}\text { Proposed WA } \\
\text { Cleanup } \\
\text { Screening } \\
\text { Level (a) }\end{array}$} & \multicolumn{7}{|c|}{ Columbia River Sediment Concentration } \\
\hline & & & $\begin{array}{l}\text { Bonneville } \\
\text { OR SH }\end{array}$ & $\begin{array}{c}\text { Dalles OR } \\
\text { SH }\end{array}$ & $\begin{array}{c}\text { Dalles WA } \\
\text { SH }\end{array}$ & $\begin{array}{c}\text { McNary 2/3 } \\
\text { OR SH }\end{array}$ & $\begin{array}{l}\text { Bonneville } \\
\text { OR Beach }\end{array}$ & $\begin{array}{c}\text { John Day } \\
\text { WA SH }\end{array}$ & $\begin{array}{l}\text { John Day } \\
\text { Mid-River }\end{array}$ \\
\hline 2-Methylnaphthalene & 470 & 560 & 330 & 330 & 330 & 330 & 330 & 330 & 330 \\
\hline Acenaphthene & 1,060 & 1,320 & 330 & 330 & 330 & 330 & 330 & 330 & 330 \\
\hline Acenaphtheylene & 470 & 640 & 330 & 330 & 330 & 330 & 330 & 330 & 330 \\
\hline Anthracene & 1,200 & 1,580 & 330 & 330 & 330 & 330 & 330 & 330 & 330 \\
\hline Benzanthracene & 4,260 & 5,800 & 330 & 330 & 330 & 330 & 330 & 330 & 330 \\
\hline Benzopyrene & 3,300 & 4,810 & 330 & 330 & 330 & 330 & 330 & 330 & 330 \\
\hline Benzofluoranthenes & 11,000 & 14,000 & 330 & 330 & 330 & 330 & 330 & 330 & 330 \\
\hline Benzoperylene & 3,300 & 4,810 & 330 & 330 & 330 & 330 & 330 & 330 & 330 \\
\hline Chrysene & 5,940 & 6,400 & 330 & 330 & 330 & 330 & 330 & 330 & 330 \\
\hline Dibenzanthracene & 800 & 840 & 330 & 330 & 330 & 330 & 330 & 330 & 330 \\
\hline Fluoranthene & 11,000 & 15,000 & 330 & 330 & 330 & 330 & 330 & 330 & 330 \\
\hline Fluorene & 1,000 & 3,000 & 330 & 330 & 330 & 330 & 330 & 330 & 330 \\
\hline Indenopyrene & 4,120 & 5,300 & 330 & 330 & 330 & 330 & 330 & 330 & 330 \\
\hline Napthalene & 500 & 1,310 & 330 & 330 & 330 & 330 & 330 & 330 & 330 \\
\hline Phenanthrene & 6,100 & 7,600 & 330 & 330 & 330 & 330 & 330 & 330 & 330 \\
\hline Pyrene & 8,800 & 16,000 & 330 & 330 & 330 & 330 & 330 & 330 & 330 \\
\hline LPAH's & 6,600 & 9,200 & -- & -- & -- & -- & -- & -- & -- \\
\hline HPAH’s & 3,100 & 54,800 & -- & -- & -- & -- & -- & -- & -- \\
\hline Bis(2-ethylhexyl)phthalate & 230 & 320 & 330 & 330 & 330 & 330 & 330 & 330 & 330 \\
\hline Butylbenzylphthalate & 260 & 370 & 330 & 330 & 330 & 330 & 330 & 330 & 330 \\
\hline Dimethylphthalate & 46 & 440 & 330 & 330 & 330 & 330 & 330 & 330 & 330 \\
\hline Di-n-octyl phthalate & 26 & 45 & 330 & 330 & 330 & 330 & 330 & 330 & 330 \\
\hline Dibenzofuran & 400 & 440 & 330 & 330 & 330 & 330 & 330 & 330 & 330 \\
\hline
\end{tabular}


Table B.5. (contd)

\begin{tabular}{|c|c|c|c|c|c|c|c|c|}
\hline \multirow[b]{2}{*}{ Analyte } & \multirow{2}{*}{$\begin{array}{l}\text { Proposed WA } \\
\text { Sediment } \\
\text { Quality } \\
\text { Standard (a) }\end{array}$} & \multirow{2}{*}{$\begin{array}{l}\text { Proposed WA } \\
\text { Cleanup } \\
\text { Screening Level } \\
\text { (a) }\end{array}$} & \multicolumn{6}{|c|}{ Columbia River Sediment Concentration } \\
\hline & & & $\begin{array}{l}\text { McNary 2/3 } \\
\text { OR SH dup }\end{array}$ & $\begin{array}{c}\text { John Day } \\
\text { OR SH }\end{array}$ & $\begin{array}{c}\text { McNary WA } \\
\text { SH }\end{array}$ & $\begin{array}{c}\text { McNary WA } \\
\text { Beach }\end{array}$ & $\begin{array}{l}\text { McNary } \\
\text { OR Beach }\end{array}$ & $\begin{array}{c}\text { McNary } \\
\text { Dam OR SH }\end{array}$ \\
\hline 2Methylnaphthalene & 470 & 560 & 330 & 330 & 330 & 330 & 330 & 330 \\
\hline Acenaphthene & 1,060 & 1,320 & 330 & 330 & 330 & 330 & 330 & 330 \\
\hline Acenaphtheylene & 470 & 640 & 330 & 330 & 330 & 330 & 330 & 330 \\
\hline Anthracene & 1,200 & 1,580 & 330 & 330 & 330 & 330 & 330 & 330 \\
\hline Benzanthracene & 4,260 & 5,800 & 330 & 330 & 330 & 330 & 330 & 330 \\
\hline Benzopyrene & 3,300 & 4,810 & 330 & 330 & 330 & 330 & 330 & 330 \\
\hline Benzofluoranthenes & 11,000 & 14,000 & 330 & 330 & 330 & 330 & 330 & 330 \\
\hline Benzoperylene & 3,300 & 4,810 & 330 & 330 & 330 & 330 & 330 & 330 \\
\hline Chrysene & 5,940 & 6,400 & 330 & 330 & 330 & 330 & 330 & 330 \\
\hline Dibenzanthracene & 800 & 840 & 330 & 330 & 330 & 330 & 330 & 330 \\
\hline Fluoranthene & 11,000 & 15,000 & 330 & 330 & 330 & 330 & 330 & 330 \\
\hline Fluorene & 1,000 & 3,000 & 330 & 330 & 330 & 330 & 330 & 330 \\
\hline Indenopyrene & 4,120 & 5,300 & 330 & 330 & 330 & 330 & 330 & 330 \\
\hline Napthalene & 500 & 1,310 & 330 & 330 & 330 & 330 & 330 & 330 \\
\hline Phenanthrene & 6,100 & 7,600 & 330 & 330 & 330 & 330 & 330 & 330 \\
\hline Pyrene & 8,800 & 16,000 & 330 & 330 & 330 & 330 & 330 & 330 \\
\hline LPAH's & 6,600 & 9,200 & - & - & - & - & - & - \\
\hline HPAH's & 3,100 & 54,800 & - & - & - & - & - & - \\
\hline Bis(2-ethylhexyl)phthalate & 230 & 320 & 330 & 330 & 330 & 330 & 330 & 330 \\
\hline Butylbenzylphthalate & 260 & 370 & 330 & 330 & 330 & 330 & 330 & 330 \\
\hline Dimethylphthalate & 46 & 440 & 330 & 330 & 330 & 330 & 330 & 330 \\
\hline Di-n-octyl phthalate & 26 & 45 & 330 & 330 & 330 & 330 & 330 & 330 \\
\hline Dibenzofuran & 400 & 440 & 330 & 330 & 330 & 330 & 330 & 330 \\
\hline
\end{tabular}

a) Michelsen, 2003. SH = Shore. 
Table B.6. Sediment Grain Size Distributions for Columbia River Sediment

\begin{tabular}{|c|c|c|c|c|c|c|c|c|}
\hline \multirow[b]{2}{*}{ Sponsor ID } & \multirow[b]{2}{*}{ Sample Description } & \multirow[b]{2}{*}{ Date } & \multirow[b]{2}{*}{$\begin{array}{c}\text { Total } \\
\text { Solids (\%) }\end{array}$} & \multicolumn{5}{|c|}{ Grain Size (Percent of Total Weight Recovered) } \\
\hline & & & & $\begin{array}{l}\text { Gravel } \\
(2.0 \mathrm{~mm})\end{array}$ & $\begin{array}{l}\text { Sand, Very } \\
\text { Coarse } \\
(1.0 \mathrm{~mm})\end{array}$ & $\begin{array}{c}\text { Sand, } \\
\text { Coarse } \\
(0.5 \mathrm{~mm})\end{array}$ & $\begin{array}{c}\text { Sand, } \\
\text { Medium } \\
(0.25 \mathrm{~mm})\end{array}$ & $\begin{array}{l}\text { Sand, Fine } \\
(0.125 \mathrm{~mm})\end{array}$ \\
\hline B17BM3 & $\begin{array}{l}\text { Bonneville Dam OR Shore } \\
\text { Beach }\end{array}$ & 08/07/2003 & 70.6 & 1.81 & 4.36 & 25.7 & 44.3 & 16.6 \\
\hline B17BM3 (Dup) & $\begin{array}{l}\text { Bonneville Dam OR Shore } \\
\text { Beach }\end{array}$ & 08/07/2003 & 70.4 & 1.74 & 4.26 & 27.5 & 45.4 & 15.0 \\
\hline B17BM3 (Tri) & $\begin{array}{l}\text { Bonneville Dam OR Shore } \\
\text { Beach }\end{array}$ & 08/07/2003 & -- & 2.02 & 4.75 & 25.9 & 45.0 & 16.5 \\
\hline B17BM5 & Bonneville Dam OR Shore & $08 / 07 / 2003$ & 53.2 & 0.02 & 0.16 & 0.39 & 1.33 & 15.0 \\
\hline B17BL9 & Dalles Dam OR Shore & 08/07/2003 & 50.7 & 0.04 & 0.10 & 0.19 & 0.47 & 3.23 \\
\hline B17BM1 & Dalles Dam WA Shore & 08/07/2003 & 72.3 & 0.11 & 0.13 & 4.02 & 39.6 & 34.6 \\
\hline B17BL4 & Johns Dam OR. Shore & $08 / 08 / 2003$ & 39.3 & 0.42 & 0.03 & 0.16 & 0.24 & 0.38 \\
\hline B17BL5 & Johns Dam Mid-River & 08/08/2003 & 29.8 & 0.00 & 0.08 & 0.51 & 3.54 & 3.95 \\
\hline B17BL6 & Johns Dam WA Shore & $08 / 08 / 2003$ & 43.0 & 0.00 & 0.05 & 0.16 & 0.79 & 4.56 \\
\hline B17BK7 & McNary OR Shore Beach & $08 / 08 / 2003$ & 75.5 & 0.40 & 1.53 & 75.6 & 20.6 & 2.71 \\
\hline B17BK8 & McNary OR Shore & 08/08/2003 & 37.6 & 0.00 & 0.00 & 0.09 & 0.29 & 0.56 \\
\hline B17BK9 & McNary 2/3 OR Shore & 08/08/2003 & 54.6 & 0.00 & 0.00 & 0.04 & 0.46 & 1.82 \\
\hline B17BK9 & McNary 2/3 OR Shore & 08/08/2003 & 54.5 & -- & -- & -- & -- & -- \\
\hline B17BL0 (Dup) & McNary 2/3 OR Shore, & $08 / 08 / 2003$ & 58.1 & 0.00 & 0.01 & 0.05 & 0.44 & 2.22 \\
\hline B17BL1 & McNary WA Shore & 08/08/2003 & 55.6 & 0.99 & 0.41 & 0.59 & 3.53 & 11.6 \\
\hline B17BL2 & McNary WA Shore Beach & 08/08/2003 & 81.3 & 0.43 & 0.11 & 1.19 & 86.2 & 10.1 \\
\hline
\end{tabular}


Table B.6. (contd)

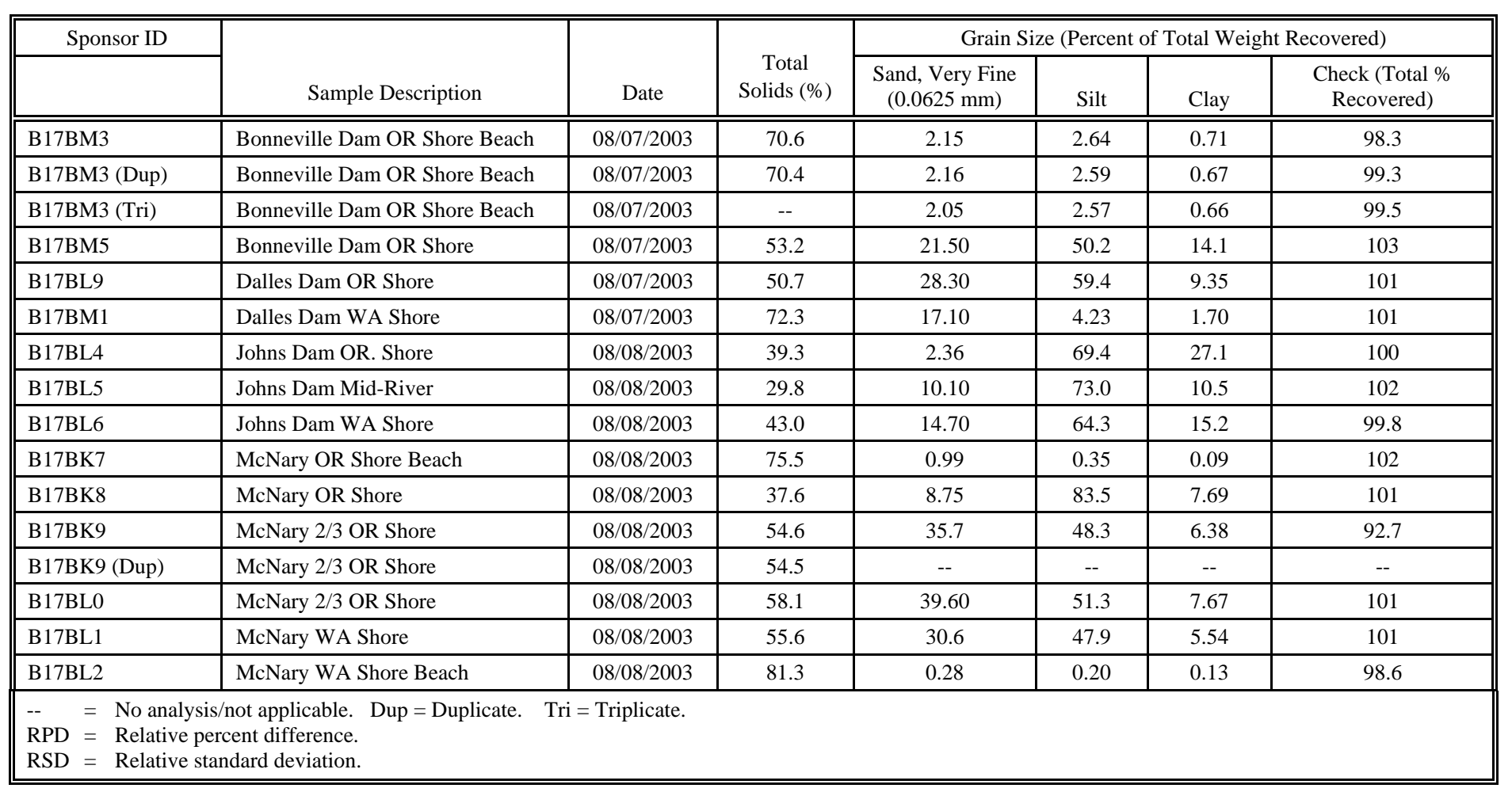


Table B.7. Total Organic Carbon Content (TOC) of Columbia River Sediment and Beach Sediment

\begin{tabular}{||c|c|l|c||}
\hline $\begin{array}{c}\text { Sample } \\
\text { No. }\end{array}$ & Date & \multicolumn{1}{c||}{ Location } & TOC (mg/kg dry wt.) \\
\hline \hline B17BR8 & 07-Aug-03 & Bonneville Dam OR Shore & 13,300 \\
\hline B17BR7 & 07-Aug-03 & Bonneville Dam OR Shore Beach & 1,110 \\
\hline B17BR3 & 07-Aug-03 & Dalles Dam OR Shore & 12,300 \\
\hline B17BR5 & 07-Aug-03 & Dalles Dam WA Shore & 1,490 \\
\hline B17BP9 & 08-Aug-03 & John Day Dam Mid-River & 16,200 \\
\hline B17BP8 & 08-Aug-03 & John Day Dam OR Shore & 13,700 \\
\hline B17BR0 & 08-Aug-03 & John Day Dam WA Shore & 13,400 \\
\hline B17BP3 & 08-Aug-03 & McNary-2/3 OR Shore & 7,190 \\
\hline B17BP4 & $08-A u g-03 ~$ & McNary-2/3 OR Shore & 7,280 \\
\hline B17BP1 & 08-Aug-03 & McNary-OR Shore Beach & 216 \\
\hline B17BP2 & 08-Aug-03 & McNary-Oregon Shore & 12,600 \\
\hline B17BP6 & 08-Aug-03 & McNary-WA Shore Beach & 214 \\
\hline B17BP5 & $08-A u g-03$ & McNary-Wash. Shore & 5,460 \\
\hline \hline
\end{tabular}


Table B.8. Radiological Results for Columbia River Water Samples Collected at McNary Dam

\begin{tabular}{|c|c|c|c|c|c|c|c|c|}
\hline Date & Location & Analyte & Result & Unit & Counting Error & $\begin{array}{c}\text { Total Analytical } \\
\text { Error }\end{array}$ & Detection Limit & Qualifier \\
\hline \multicolumn{9}{|c|}{ PNNL Results } \\
\hline 08-Aug-03 & McNary-Oregon Shore & Sr-90 & 0.152 & $\mathrm{pCi} / \mathrm{L}$ & 0.022 & 0.032 & 0.0252 & \\
\hline 08-Aug-03 & McNary-2/3 OR Shore & Be-7 & -0.959 & $\mathrm{pCi} / \mathrm{L}$ & 23 & 23 & 40.4 & $\mathrm{U}$ \\
\hline 08-Aug-03 & McNary-2/3 OR Shore & Co-60 & 4.42 & $\mathrm{pCi} / \mathrm{L}$ & 3.1 & 3.1 & 7.18 & $\mathrm{U}$ \\
\hline 08-Aug-03 & McNary-2/3 OR Shore & Cs-134 & 0.699 & $\mathrm{pCi} / \mathrm{L}$ & 3.3 & 3.3 & 6.18 & $\mathrm{U}$ \\
\hline 08-Aug-03 & McNary-2/3 OR Shore & Cs-137 & -3.15 & $\mathrm{pCi} / \mathrm{L}$ & 2.6 & 2.6 & 3.77 & $\mathrm{U}$ \\
\hline 08-Aug-03 & McNary-2/3 OR Shore & Eu-152 & -4.22 & $\mathrm{pCi} / \mathrm{L}$ & 6.8 & 6.8 & 11.6 & $\mathrm{U}$ \\
\hline 08-Aug-03 & McNary-2/3 OR Shore & Eu-154 & -1.08 & $\mathrm{pCi} / \mathrm{L}$ & 7.9 & 7.9 & 14.9 & $\mathrm{U}$ \\
\hline 08-Aug-03 & McNary-2/3 OR Shore & Eu-155 & -1.13 & $\mathrm{pCi} / \mathrm{L}$ & 5.7 & 5.7 & 10.2 & $\mathrm{U}$ \\
\hline 08-Aug-03 & McNary-2/3 OR Shore & $\mathrm{K}-40$ & -41.5 & $\mathrm{pCi} / \mathrm{L}$ & 66 & 66 & 145 & $\mathrm{U}$ \\
\hline 08-Aug-03 & McNary-2/3 OR Shore & $\mathrm{Pu}-238$ & -0.0000285 & $\mathrm{pCi} / \mathrm{L}$ & 0.0033 & 0.0033 & 0.00849 & $\mathrm{U}$ \\
\hline 08-Aug-03 & McNary-2/3 OR Shore & $\mathrm{Pu}-239 / 240$ & 0.00177 & $\mathrm{pCi} / \mathrm{L}$ & 0.0033 & 0.0033 & 0.00313 & $\mathrm{U}$ \\
\hline 08-Aug-03 & McNary-2/3 OR Shore & Ru-106 & 4.27 & $\mathrm{pCi} / \mathrm{L}$ & 21 & 21 & 39.7 & $\mathrm{U}$ \\
\hline 08-Aug-03 & McNary-2/3 OR Shore & Sb-125 & 0.131 & $\mathrm{pCi} / \mathrm{L}$ & 6.1 & 6.1 & 11 & $\mathrm{U}$ \\
\hline 08-Aug-03 & McNary-2/3 OR Shore & Sr-90 & 0.115 & $\mathrm{pCi} / \mathrm{L}$ & 0.022 & 0.029 & 0.029 & \\
\hline 08-Aug-03 & McNary-2/3 OR Shore & U-234 & 0.253 & $\mathrm{pCi} / \mathrm{L}$ & 0.038 & 0.055 & 0.01 & \\
\hline 08-Aug-03 & McNary-2/3 OR Shore & $\mathrm{U}-235$ & 0.00349 & $\mathrm{pCi} / \mathrm{L}$ & 0.0061 & 0.0064 & 0.0037 & $\mathrm{U}$ \\
\hline 08-Aug-03 & McNary-2/3 OR Shore & $\mathrm{U}-238$ & 0.188 & $\mathrm{pCi} / \mathrm{L}$ & 0.033 & 0.044 & 0.0127 & \\
\hline 08-Aug-03 & McNary-WA Shore & Sr-90 & 0.123 & $\mathrm{pCi} / \mathrm{L}$ & 0.023 & 0.03 & 0.0296 & \\
\hline \multicolumn{9}{|c|}{ ODOE Results } \\
\hline 08-Aug-03 & McNary-2/3 OR Shore & Co-60 & 0.005 & $\mathrm{pCi} / \mathrm{L}$ & 0.003 & & & \\
\hline 08-Aug-03 & McNary-2/3 OR Shore & Co-60 & 0.009 & $\mathrm{pCi} / \mathrm{L}$ & 0.005 & & & \\
\hline 08-Aug-03 & McNary-2/3 OR Shore & Cs-137 & ND & $\mathrm{pCi} / \mathrm{L}$ & & & & \\
\hline 08-Aug-03 & McNary-2/3 OR Shore & Cs-137 & ND & $\mathrm{pCi} / \mathrm{L}$ & & & & \\
\hline 08-Aug-03 & McNary-2/3 OR Shore & $\mathrm{K}-40$ & 0.2 & $\mathrm{pCi} / \mathrm{L}$ & 0.111 & & & \\
\hline 08-Aug-03 & McNar-2/3 OR Shore & $\mathrm{K}-40$ & 0.3 & $\mathrm{pCi} / \mathrm{L}$ & 0.12 & & & \\
\hline
\end{tabular}




\section{B.9 References}

Michelsen TM. 2003. Development of Freshwater Sediment Quality Values for Use in Washington State. Phase II Report: Development and Recommendations for SQVs for Freshwater Sediment in Washington State. Pub. No. 03-09-088. Avocet Consulting (Kenmore, Washington) under contract to Science Applications International Corporation (Bothell, Washington). 